\title{
AVALIAÇÃO DE DANOS E EFEITO DE VARIÁVEIS AMBIENTAIS NA MANCHA DE ALTERNARIA (Alternaria helianthi) EM GIRASSOL
}

\author{
REGINA MARIA VILLAS BÔAS DE CAMPOS LEITE
}

Tese apresentada à Escola Superior de Agricultura "Luiz de Queiroz", Universidade de São Paulo, para obtenção do título de Doutor em Agronomia, Área de Concentração: Fitopatologia.

PIRACICABA

Estado de São Paulo - Brasil

Julho - 2002 


\title{
AVALIAÇÃO DE DANOS E EFEITO DE VARIÁVEIS AMBIENTAIS NA MANCHA DE ALTERNARIA (Alternaria helianthi) EM GIRASSOL
}

\section{REGINA MARIA VILLAS BÔAS DE CAMPOS LEITE}

\author{
Engenheiro Agrônomo
}

Orientadora: Profa. Dra. LILIAN AMORIM

Tese apresentada à Escola Superior de Agricultura "Luiz de Queiroz", Universidade de São Paulo, para obtenção do título de Doutor em Agronomia, Área de Concentração: Fitopatologia.

PIRACICABA

Estado de São Paulo - Brasil

Julho - 2002 
Dados Internacionais de Catalogação na Publicação (CIP)

DIVISÃO DE BIBLIOTECA E DOCUMENTAÇÃO - ESALQ/USP

Leite, Regina Maria Villas Bôas de Campos

Avaliação de danos e efeitos de variáveis ambientais na mancha de altemaria (Altemaria helianthi) em girassol / Regina Maria Villas Bôas de Campos Leite. - - Pirac ic aba, 2002.

107 p. : il.

Tese (doutorado) - Escola Superior de Agricultura Luiz de Queiroz, 2002.

Bibliografia.

1. Danos 2. Efeito da temperatura 3. Girassol 4. Mancha-d e-altema ria I. Título

CDD 633.39

"Permitida a cópia total ou parcial deste documento, desde que citada a fonte - O autor" 
“Também eu vos digo: pedi e vos será dado;

buscai e achareis; batei e vos será aberto.

Pois todo o que pede, recebe; o que busca, acha; e ao que bate, se abrirá."

Lc 11, 9-10

Aos meus pais Danton e Gladys (in memoriam), Com saudades

Aos meus sogros Fernão e Isolina,

Verdadeiros pais durante esta caminhada

Ao meu marido Fernão,

Companheiro de todas as horas, com muito amor

E ao nosso filho Lucas,

Presente de Deus que nos veio encher de alegria 


\section{AGRADECIMENTOS}

À minha orientadora, Profa. Dra. Lilian Amorim, exemplo de competência e dedicação ao ensino e à pesquisa em Fitopatologia, pelos ensinamentos fundamentais para a minha formação, acolhimento e amizade.

À Escola Superior de Agricultura "Luiz de Queiroz" - Universidade de São Paulo, Departamento de Entomologia, Fitopatologia e Zoologia Agrícola, Setor de Fitopatologia, pela oportunidade de realizar este curso de Doutorado.

À Empresa Brasileira de Pesquisa Agropecuária - Centro Nacional de Pesquisa de Soja, pelo apoio que possibilitou a realização deste curso de Pós-Graduação.

Ao Prof. Dr. Armando Bergamin Filho, pela sugestão do assunto e colaboração na realização deste trabalho.

Aos professores, funcionários e estagiários do Departamento, pelos ensinamentos e auxílio em vários momentos.

Ao meu conselheiro acadêmico Dr. Álvaro Manuel Rodrigues Almeida, pesquisador da Embrapa Soja, pelo encaminhamento e incentivo que culminou na realização desta pesquisa. 
A todos os colegas da Pós-Graduação, em especial a Alice Maria Quezado Duval, Celia Correia Malvas, José Magno Martins Bringel e Louise Larissa May de Mio, pelo agradável convívio, companheirismo e amizade.

Aos colegas pesquisadores e funcionários da Equipe de Girassol da Embrapa Soja, pelo apoio e auxílio na realização deste trabalho de pesquisa, especialmente aos técnicos agrícolas Esmael da Silva e Roberval Aparecido Fagundes e ao auxiliar de operações Valdenir Saldeira, que não mediram esforços em instalar e avaliar semanalmente meus experimentos de campo, sem os quais este trabalho não poderia ser realizado.

À secretária da Embrapa Soja Iraci Yoshico Imazu, pela dedicação e presteza em me ajudar a solucionar problemas.

Às bibliotecárias da ESALQ-USP, pela revisão da bibliografia, revisão da tese e elaboração da ficha catalográfica.

Aos funcionários e estagiários da Biblioteca da Embrapa Soja, pela colaboração na pesquisa bibliográfica.

Ao Conselho Nacional de Desenvolvimento Científico e Tecnológico - CNPq, pela concessão da bolsa de estudos.

A todas as pessoas aqui não mencionadas que, de alguma forma, contribuíram para que este Doutorado se tornasse uma realidade. 


\section{SUMÁRIO}

\begin{tabular}{|c|c|}
\hline & ’ágina \\
\hline RESUMO . & viii \\
\hline SUMMARY & $\mathrm{X}$ \\
\hline 1 INTRODUÇÃO & 1 \\
\hline 2 REVISÃO DE LITERATURA & 5 \\
\hline 2.1 Mancha de Alternaria . & 5 \\
\hline 2.1.1 Importância .............. & 5 \\
\hline 2.1.2 Etiologia .............. & 5 \\
\hline 2.1.3 Sintomas ........................ & 6 \\
\hline 2.1.4 Epidemiologia .... & 7 \\
\hline 2.2 Quantificação de danos . & 9 \\
\hline 2.2.1 Danos causados pela mancha de Alternaria . & 11 \\
\hline 3 ELABORAÇÃO E VALIDAÇÃO DE ESCALA DIAGRAMÁTICA PARA & \\
\hline MANCHA DE ALTERNARIA EM GIRASSOL …..................................... & 13 \\
\hline Resumo & 13 \\
\hline Summary & 14 \\
\hline 3.1 Introdução ...................... & 14 \\
\hline 3.2 Material e Métodos ........ & 17 \\
\hline 3.3 Resultados e Discussão ............................. & 19 \\
\hline 3.4 Conclusões . ............................................ & 26 \\
\hline 4 INFLUÊNCIA DA TEMPERATURA E DO MOLHAMENTO FOLIAR NO & \\
\hline MONOCICLO DA MANCHA DE ALTERNARIA EM GIRASSOL & 27 \\
\hline Resumo & 27 \\
\hline Immary & 28 \\
\hline
\end{tabular}




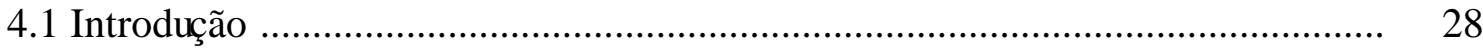

4.2 Material e Métodos .................................................................................. 29

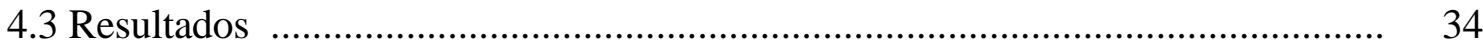

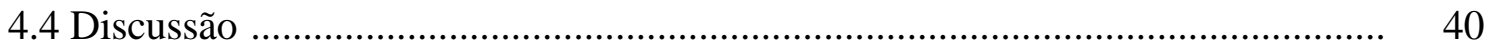

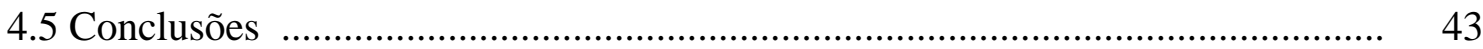

5 RELAÇÕES DE VARIÁVEIS DE DOENÇA E DE ÁREA FOLIAR COM COMPONENTES DE PRODUÇÃO PARA O PATOSSISTEMA Alternaria

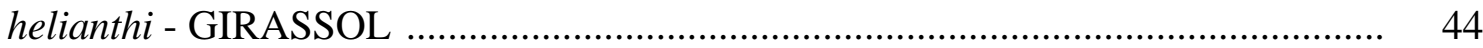

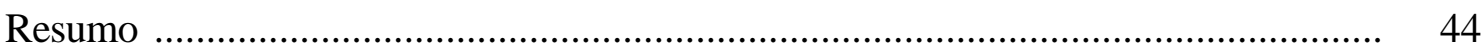

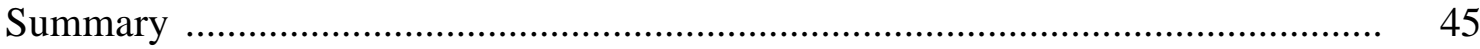

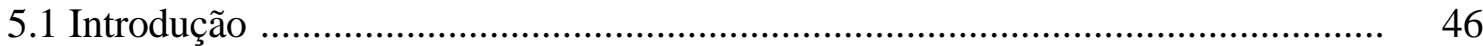

5.2 Material e Métodos .................................................................................. 47

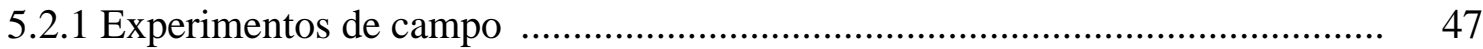

5.2.2 Avaliações de desenvolvimento das plantas, severidade da doença e

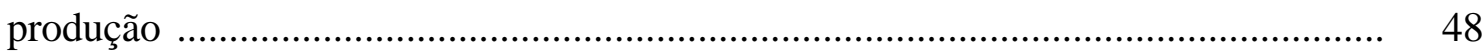

5.2.3 AUDPC, LAI, HLAI, HAD, RI, HRI e HAA ............................................ 49

5.2.4 Análises de regressão linear e não-linear ................................................... 51

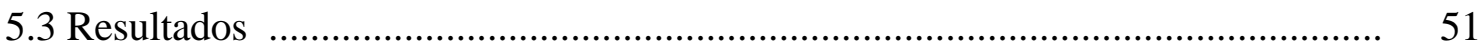

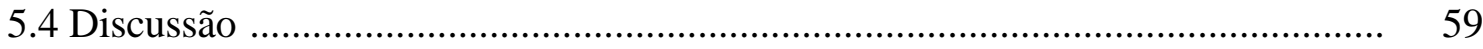

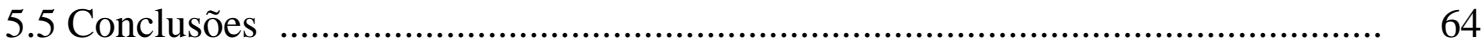

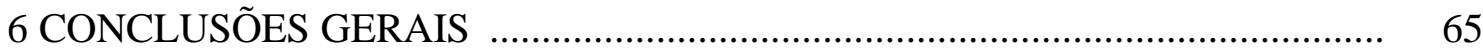

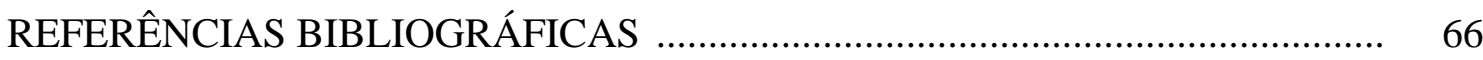

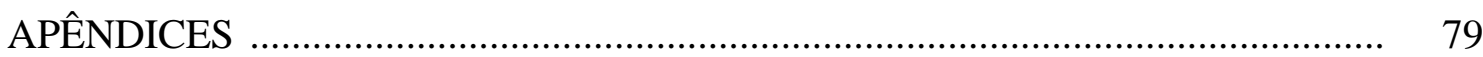




\title{
AVALIAÇÃO DE DANOS E EFEITO DE VARIÁVEIS AMBIENTAIS NA MANCHA DE ALTERNARIA (Alternaria helianthi) EM GIRASSOL
}

\author{
Autora: REGINA MARIA VILLAS BÔAS DE CAMPOS LEITE
}

Orientadora: Profa. Dra. LILIAN AMORIM

\section{RESUMO}

\begin{abstract}
O desenvolvimento e implementação de uma estratégia de manejo integrado de doenças na cultura do girassol (Helianthus annuиs) requer informações precisas e acuradas sobre os danos causados pela mancha de Alternaria, causada por Alternaria helianthi. Os objetivos desta tese foram: elaborar e validar uma escala diagramática para avaliação da mancha de Alternaria; determinar a influência da temperatura (15-32,5 $\left.{ }^{\circ} \mathrm{C}\right)$ e da duração do período de molhamento foliar (2-24 h) nos componentes monocíclicos da doença; comparar a relação de variáveis relacionadas à doença ou à área foliar com os componentes de produção de girassol, em experimentos de campo. A escala diagramática, com níveis de severidade de: 0,$03 ; 0,2 ; 0,6 ; 3 ; 7 ; 12$; 25; 40 e 66\% da área foliar lesionada, foi validada por três avaliadores experientes. A escala permitiu que se fizesse uma avaliação acurada e precisa, quando se utilizou folhas desenhadas ou folhas verdes com sintomas. $\mathrm{O}$ erro absoluto ao estimar a severidade foi menor que $13 \%$ e a reprodutibilidade das avaliações foi alta. Em ambiente controlado, verificourse que a densidade relativa de lesões e a severidade foram influenciadas pela
\end{abstract}


temperatura e pela duração do período de molhamento foliar. A doença foi mais severa na temperatura de $25{ }^{\circ} \mathrm{C}$. A temperatura mínima para desenvolvimento da doença foi de $13,0^{\circ} \mathrm{C}$ e a máxima foi de $35,8^{\circ} \mathrm{C}$. A doença aumentou com o aumento da duração do período de molhamento foliar. A temperatura mínima estimada para a taxa de crescimento micelial foi de $5,5^{\circ} \mathrm{C}$ e a máxima foi de $32,9^{\circ} \mathrm{C}$. A temperatura mínima estimada para germinação de conídios foi de $7,9{ }^{\circ} \mathrm{C}$ e a máxima foi de $40,0{ }^{\circ} \mathrm{C}$. Experimentos foram conduzidos nas safras de 1997/1998, 1998/1999 e 1999/2000 para avaliar a relação entre severidade da mancha de Alternaria, área sob a curva de progresso da doença $(A U D P C)$, índice de área foliar sadia em determinado dia (HLAI), duração da área foliar sadia $(H A D)$, radiação interceptada pela área foliar sadia em determinado dia $(H R I)$, absorção da área foliar sadia $(H A A)$ e componentes de produção de girassol, semeado em quatro épocas. A $A U D P C$ teve relação com rendimento de aquênios, com ajuste do modelo exponencial negativo em duas safras. A relação rendimento x $H A D$ foi linear para os três experimentos. Para as variáveis integrais estudadas, a melhor relação com rendimento foi verificada para $H A A$, com ajuste do modelo exponencial. A taxa da relação severidade $\mathrm{x}$ rendimento tendeu a se estabilizar a partir da fase de desenvolvimento R1. A taxa da relação linear entre HLAI e rendimento estabilizou-se entre as fases R1 a R6. A taxa da regressão entre $H R I$ e rendimento foi bastante variável e não mostrou tendência de estabilização. Verificou-se que plantas que apresentaram severidade maior que $10 \%$ na fase de desenvolvimento R3 produziram rendimentos inferiores a $500 \mathrm{~kg} / \mathrm{ha}$, para as três safras, independentemente da época de semeadura, o que pode ser utilizado como um Imiar de dano. A severidade pode ser usada como uma variável independente para um sistema de manejo da mancha de Alternaria em girassol. 


\title{
DAMAGE ASSESSMENT AND EFFECT OF ENVIRONMENTAL VARIABLES ON ALTERNARIA LEAF SPOT (Alternaria helianthi) IN SUNFLOWER
}

\author{
Author: REGINA MARIA VILLAS BÔAS DE CAMPOS LEITE \\ Adviser: Prof. Dr. LILIAN AMORIM
}

\section{SUMMARY}

The development and implementation of integrated disease-management system on sunflower (Helianthus annuиs) require precise and accurate information on the damage caused by Alternaria leaf spot (Alternaria helianthi). The objectives of this thesis were: to develop and to validate a diagrammatic scale for Alternaria leaf spot; to determine the influence of temperature $\left(15-32.5{ }^{\circ} \mathrm{C}\right)$ and leaf wetness duration $(2-24 \mathrm{~h})$ on the monocycle of the disease; and to compare the relationship between variables related to Alternaria leaf spot or to leaf area and yield, in field experiments. The diagrammatic scale with levels representing: $0.03 ; 0.2 ; 0.6 ; 3 ; 7 ; 12 ; 25 ; 40$; and $66 \%$ of diseased leaf area was validated by three experienced raters. The scale permitted assessments to be accurate and precise, when drawn or detached leaves were used. The absolute error in estimating disease severity was lower than $13 \%$ and the reproducibility of assessments was high. In controlled environment studies, relative lesion density and severity were influenced by temperature and leaf wetness duration. The disease was more severe in the temperature of $25{ }^{\circ} \mathrm{C}$. The minimum temperature for disease 
development was $13.0{ }^{\circ} \mathrm{C}$ and the maximum was $35.8{ }^{\circ} \mathrm{C}$. The disease increased with increasing periods of leaf wetness. The estimated minimum temperature for mycelial growth rate was $5.5{ }^{\circ} \mathrm{C}$ and the maximum was $32.9{ }^{\circ} \mathrm{C}$. The estimated minimum temperature for conidia germination was $7.9^{\circ} \mathrm{C}$ and the maximum was $40.0^{\circ} \mathrm{C}$. Three field experiments were carried out in 1997/1998, 1998/1999 and 1999/2000 to investigate the relationship between severity of Alternaria leaf spot, area under disease progress curve $(A U D P C)$, healthy leaf area index at any given day (HLAI), healthy leaf area duration $(H A D)$, radiation intercepted by healthy leaf area at any given day $(H R I)$, total healthy leaf area absorption (HAA), and yield components of sunflower, sowed in four dates. $A U D P C$ showed relationship with yield in two years, following the negative exponential model. The yield x $H A D$ relationship was linear for each of three trials. Among the integral variables analyzed, the yield $\mathrm{x} H A A$ relationship was the best one, fitted by the exponential model. The slope of the yield-severity relationship was stable from R1 growth stage. The yield-HLAI relationship was stable between R1 and R6. The yield-HRI relationship was variable and not stable. The yield-severity relationship in R3 growth stage proved that plants with severity higher than $10 \%$ had yield lower than 500 $\mathrm{kg} / \mathrm{ha}$, despite the sowing date, which can be used as a damage threshold. Severity can be used as an independent variable to a system of sunflower Alternaria leaf spot management. 


\section{INTRODUÇÃO}

O girassol (Helianthus annuus L.) é uma dicotiledônea anual da família Compositae, originária do continente Norte Americano. Atualmente, o girassol é cultivado em todos os continentes, em área que atinge aproximadamente 19,17 milhões de hectares, com uma produção mundial estimada para safra 2001/2002 de 21,37 milhões de toneladas (Estados Unidos, 2002).

É uma oleaginosa que apresenta características agronômicas importantes, como maior resistência à seca, ao frio e ao calor que a maioria das espécies normalmente cultivadas no Brasil. Apresenta ampla adaptabilidade às diferentes condições edafoclimáticas e seu rendimento é pouco influenciado pela latitude, pela altitude e pelo fotoperíodo. Graças a essas características, apresenta-se como uma opção nos sistemas de rotação e sucessão de culturas nas regiões produtoras de grãos (Castro et al., 1996).

Dentre os óleos vegetais, o óleo de girassol destaca-se por suas excelentes características físico-químicas e nutricionais. Possui alta relação de ácidos graxos poliinsaturados/saturados $(65,3 \% / 11,6 \%$, em média). O teor de poliinsaturados é constituído, em sua quase totalidade, pelo ácido linoléico (65\%, em média). Este é essencial ao desempenho das funções fisiológicas do organismo humano e deve ser ingerido através dos alimentos, já que não é sintetizado pelo homem. Por essas características, é um dos óleos vegetais de melhor qualidade nutricional e organoléptica do mundo, contribuindo para a prevenção de diferentes doenças cardiovasculares e no controle do nível de colesterol no sangue (Castro et al., 1996).

Um dos fatores limitantes para a produção de girassol no mundo é a ocorrência de doenças. Estima-se que as doenças causam uma perda anual de $12 \%$ da produção de girassol no mundo (Zimmer \& Hoes, 1978). No Brasil, não há dados exatos 
sobre qual o dano na produção provocado pelas doenças, mas sabe-se que este pode ser mínimo ou chegar a 100\%, dependendo das condições climáticas (Yorinori et al., 1985).

O girassol cultivado (H. annuus) e as espécies de Helianthus perenes são hospedeiros de uma ampla variedade de fungos, bactérias e vírus. O girassol é hospedeiro de mais de 35 microrganismos, a maioria fungos, que podem, dependendo de condições climáticas, levar à redução significativa da produção e qualidade do produto, podendo prejudicar a expansão da cultura (Zimmer \& Hoes, 1978).

O histórico da produção de girassol no Brasil está sempre ligado com a ocorrência de doenças, já que este é um importante fator que limita a expansão da cultura nas diferentes regiões e épocas de semeadura. Em 1960, o Brasil dispunha de uma área de 360 hectares cultivada com girassol e um rendimento médio em torno de $833 \mathrm{~kg} / \mathrm{ha}$. Até 1969, houve um aumento gradativo da área cultivada, atingindo-se uma área total de 15.300 hectares com rendimento médio de $1180 \mathrm{~kg} / \mathrm{ha}$. Entretanto, nos anos subseqüentes, houve um decréscimo no cultivo do girassol, atribuído à falta de tecnologia de produção; ao baixo teor de óleo nos genótipos disponíveis; aos problemas de suscetibilidade dos genótipos a doenças fúngicas e à falta de organização na comercialização. A partir de 1979, particularmente no oeste do Estado do Paraná, houve um novo interesse pela cultura. No ano de 1981, atingiu-se uma área de 58.000 ha. Entretanto, a falta de informações tecnológicas, tais como época adequada de semeadura, genótipos e manejo da cultura, teve como conseqüência uma redução drástica no rendimento $(460 \mathrm{~kg} / \mathrm{ha})$, devido principalmente à proliferação de doenças fúngicas, como a mancha de Alternaria, causada por Alternaria helianthi (Hansf.) Tubaki \& Nishihara, e a podridão de capítulo, causada por Sclerotinia sclerotiorum (Lib.) de Bary (Dall'Agnol et al., 1994). Essas experiências negativas foram uma das causas que desestimularam os produtores para investir no cultivo de girassol.

Atualmente, o girassol apresenta perspectivas de incremento significativo na área cultivada, principalmente na Região Centro-Oeste e nos Estados de São Paulo, Paraná e Rio Grande do Sul. Esta tendência se dá em função da necessidade de rotação de culturas e do interesse manifestado pelos setores industriais e comerciais. No ano 2000, estima-se que a cultura ocupou uma área de aproximadamente 90.000 hectares no 
Brasil, área esta que pode aumentar em função da diversidade de utilização, como alternativa para entressafra ou reforma de canaviais, silagem ou na forma de flores (Vieira, 2001).

Em levantamentos realizados no início da década de 80, cerca de 16 doenças foram relatadas no Brasil. Algumas têm importância significativa, sendo a mancha de Alternaria e a podridão branca as mais prejudiciais à cultura (EMBRAPACNPSo, 1983). A podridão branca do capítulo ocorre principalmente em condições de temperatura amena e alta umidade, o que praticamente inviabiliza o cultivo de girassol como cultura comercial, no período de outono na Região Sul do País. Observações realizadas recentemente indicaram que a mancha de Alternaria é a doença predominante em todas as épocas de semeadura, nas diferentes regiões de cultivo (Leite, 1997).

O desenvolvimento e implementação de uma estratégia de manejo integrado de doenças na cultura do girassol requer informações precisas e acuradas a respeito dos danos causados pelos patógenos. A necessidade de padronização nos métodos utilizados na avaliação de doenças se faz presente, já que a uniformidade de metodologia permite a comparação de resultados obtidos em experimentos conduzidos por instituições públicas e privadas, em diferentes localidades (Amorim, 1995; Bergamin Filho \& Amorim, 1996). A quantificação de danos é, portanto, um ponto chave na definição de qualquer estratégia ou tática de controle (Bergamin Filho \& Amorim, 1996).

Historicamente, diversos modelos têm sido utilizados para descrever a relação entre a severidade da doença e a produtividade, considerando uma única ou várias fases de desenvolvimento da planta. Modelos integrais geralmente relacionam os componentes de produção com a área sob a curva de progresso da doença. Entretanto, esses modelos nem sempre são transportáveis para a previsão de danos em outras localidades e safras agrícolas (Bergamin Filho \& Amorim, 1996).

Poucos estudos têm sido realizados sobre a avaliação quantitativa de danos causados por doenças em girassol. Em estudo publicado em 1987, as avaliações de severidade da doença e área sob a curva de progresso da mancha de Alternaria não 
foram consistentemente correlacionadas com os componentes de produção, como produção de grãos, teor de óleo e peso de sementes (Carson, 1987).

A produtividade é função da área foliar da planta e da interceptação da radiação solar. No contexto fitopatológico, é importante considerar a área foliar que permanece sadia durante o ciclo, ou seja, que não foi afetada pela doença. Assim, é importante fazer a comparação entre a relação radiação capturada pela área foliar sadia da planta durante todo o seu desenvolvimento x produtividade e a relação severidade da doença $\mathrm{x}$ produtividade, para melhor basear as estratégias de manejo da doença (Bergamin Filho \& Amorim, 1996).

Os objetivos desta tese foram:

Elaborar e validar uma escala diagramática para avaliação da mancha de Alternaria em girassol, utilizando critérios que respeitam os limites da acuidade visual humana e normas de elaboração de escalas diagramáticas previamente definidas;

Determinar a influência da temperatura e da duração do período de molhamento foliar no desenvolvimento da mancha de Alternaria, sob condições controladas e o efeito da temperatura na taxa de crescimento micelial e na germinação de conídios de A. helianthi, em laboratório;

Comparar a relação de componentes integrais ou pontuais relacionados à mancha de Alternaria ou à área foliar com os componentes de produção de girassol, por meio de estudos epidemiológicos, em experimentos de campo. 


\section{REVISÃO DE LITERATURA}

\subsection{Mancha de Alternaria}

\subsubsection{Importância}

Identificada no Brasil na década de 70 (Ribeiro et al., 1974), a mancha de Alternaria é uma das principais doenças que ocorrem no País, estando presente em todas as regiões. A doença afeta a planta pela diminuição da área fotossintética, devido à formação de manchas foliares e à desfolha precoce, resultando na redução do diâmetro dos capítulos, do número de aquênios por capítulo, do peso de 1000 aquênios e do teor de óleo. Plantas severamente afetadas apresentam a maturação antecipada. Além do Brasil, a doença ocorre em países da América do Norte e da África, além da Argentina, Índia, Japão, Austrália, antiga Iugoslávia, Romênia e França (Anahosur, 1978; Davet et al., 1991; Pereyra \& Escande, 1994; Zimmer \& Hoes, 1978). Na Índia, em condições ótimas para infecção, plantas podem apresentar mortalidade de $100 \%$ ou, ainda, reduções da ordem de $95,8 \%$ na produção de grãos e de $96,3 \%$ no teor de óleo, indicando o potencial devastador da doença (Ghemawat et al., 1989; Sahu et al., 1991).

\subsubsection{Etiologia}

Várias espécies de Alternaria causam sintomas semelhantes em plantas de girassol. Três espécies do fungo são relatadas como patogênicas ao girassol no Brasil: $A$. helianthi (Hansf.) Tubaki \& Nishihara (sin. Helminthosporium helianthi Hansf.), A. zinniae Ellis e A. alternata (Fr.) Keissler (sin. A. tenuis Nees). A identificação da espécie de Alternaria é feita com base na forma e no tamanho dos conídios (Gulya et al., 1997). 
Os conídios de A. helianthi, de formato cilíndrico a elipsoidal, coloridos, não possuem cauda e são formados isoladamente em conidióforos cilíndricos e solitários. A. helianthi é também patogênico ao crisântemo. Não há relatos de especialização fisiológica do fungo em girassol (Anahosur, 1978). A. zinniae produz conídios com cauda longa, característica esta que a distingue de outras espécies de Alternaria patogênicas ao girassol (David, 1991).

A. alternata possui conídios piriformes e de coloração marrom a marromamarelada (Zimmer \& Hoes, 1978). Foi proposta a nomenclatura de A. alternata f.sp. helianthina ao patótipo dessa espécie de fungo que causa doença em girassol, já que não se mostrou patogênico a outras espécies de plantas testadas (Lagopodi \& Thanassoulopoulos, 1996).

\subsubsection{Sintomas}

Os sintomas iniciais típicos nas folhas são pequenas pontuações necróticas com cerca de 3 a $5 \mathrm{~mm}$ de diâmetro, de coloração variável da castanha à negra, de formato arredondado a angular, com halo clorótico. As lesões características apresentam círculos concêntricos, semelhantes a um alvo. Essas lesões podem coalescer, formando áreas extensas de tecido necrosado, provocando a seca prematura da folha e, conseqüentemente, a desfolha precoce das plantas. Os sintomas manifestam-se primeiramente nas folhas mais baixas, expandindo, posteriormente, para toda a planta. Entretanto, pode ocorrer infecção generalizada das folhas, independentemente de sua posição na planta (Almeida et al., 1981; Anahosur, 1978; Davet et al., 1991; Gulya et al., 1997).

$\mathrm{Na}$ haste e nos pecíolos, as lesões iniciam-se como pequenos pontos ou riscas e, quando numerosas, formam grandes áreas necróticas, evoluindo até tomar toda a haste. Em condições de ataque severo, a doença provoca crestamento total e, finalmente, morte da planta. A quebra de hastes também é comum. Em plântulas, o fungo pode ocasionar queima dos tecidos em desenvolvimento (Almeida et al., 1981; Anahosur, 1978; Davet et al., 1991; Gulya et al., 1997). 
Em plantas adultas, coloniza as brácteas e o receptáculo floral, podendo, inclusive, causar podridão de capítulo (Almeida et al., 1981; Anahosur, 1978; Davet et al., 1991).

\subsubsection{Epidemiologia}

O fungo pode ser transmitido pela semente, sendo constatada sua presença internamente e no tegumento ou em fragmentos de plantas presentes no lote, podendo permanecer viável por muitos anos (Godoy \& Fernandes, 1985a; Gulya et al., 1997). Entretanto, a principal fonte de inóculo primário é constituída por restos de cultura infectados com o fungo (Davet et al., 1991).

Em condições favoráveis, o fungo produz grande quantidade de conídios e, em pouco tempo, através do transporte dos conídios pelo vento e pela chuva, pode se alastrar para outras partes da planta ou para outras plantas. As condições ótimas para a germinação de conídios de Alternaria spp. são alta umidade relativa e temperatura entre $25^{\circ} \mathrm{C}$ e $30^{\circ} \mathrm{C}$ (Davet et al., 1991). Existem relatos de que a presença de pólen, que cai das flores sobre as folhas, estimula a germinação dos conídios (Pereyra \& Escande, 1994). Os tubos germinativos penetram diretamente através da cutícula e da epiderme (Davet et al., 1991).

Em condições de cultivo em laboratório, A. helianthi pode esporular nas temperaturas entre 5 e $40^{\circ} \mathrm{C}$, com o ótimo entre 25 e $30^{\circ} \mathrm{C}$ (Masirevic, 1995). Estudo conduzido por Abbas et al. (1995) indicou que a infectividade e a germinação dos conídios diminuíram com o aumento da temperatura de produção dos mesmos, em meio de cultura. Conídios produzidos na temperatura de 28 a $30^{\circ} \mathrm{C}$ foram não infectivos ao hospedeiro.

Melhores crescimento de colônias e esporulação são obtidos em meios de cultura naturais, como meio de farinha de aveia, de cenoura, de extrato de sementes de girassol e de extrato de folhas de girassol, do que meios sintéticos ou semi-sintéticos, como BDA (batata-dextrose-ágar) (Allen et al., 1983b; Leite, 1996; Mukewar \& Gera, 1980; Srinivas et al., 1997).

As plantas de girassol são suscetíveis durante todos os estádios de desenvolvimento (Sahu et al., 1991), com uma fase de maior suscetibilidade desde o 
surgimento das anteras até o enchimento de grãos (Anahosur, 1978; Davet et al., 1991). As folhas baixeiras são mais severamente atacadas (Somasundara \& Anilkumar, 1990) e a doença avança rapidamente das folhas mais baixas para as folhas do ponteiro.

Maior severidade é observada em estádios mais adiantados de desenvolvimento, após o florescimento (Allen et al., 1983b; Godoy \& Fernandes, 1985b; Pereyra \& Escande, 1994). Entretanto, em condições ótimas para infecção, plantas de 15 dias de idade podem apresentar mortalidade de 100\% (Sahu et al., 1991). Ghemawat et al. (1989) verificaram que, apesar da mortalidade ser reduzida a 13,3\% quando as plantas estavam com um mês de idade, ainda foram observadas reduções drásticas de 95,8\% na produção de grãos e de $96,3 \%$ no teor de óleo.

A influência do clima na epidemiologia da mancha de Alternaria foi estudada em 12 épocas de semeadura, no Estado de São Paulo, por meio da análise da curva de progresso da doença e de correlações de sua intensidade com variáveis climáticas, mostrando que a variável precipitação foi a que mostrou maior influência sobre a taxa de infecção aparente da doença em girassol (Sentelhas et al., 1996). Nessas mesmas condições, a semeadura do mês de agosto mostrou, na média, a menor área sob a curva de progresso da doença e o menor índice de doença, como consequiência de pouca quantidade de chuva no período (Dudienas et al., 1998).

$\mathrm{Na}$ Índia, os parâmetros meteorológicos que favoreceram a doença foram a temperatura entre 25,9 e $33,7^{\circ} \mathrm{C}$ e umidade relativa de 89 a $95 \%$. O desenvolvimento da doença foi maior quando ocorreram chuvas intermitentes de 1,2 a 12,8 mm em uma semana (Borkar \& Patil, 1995). Um período de molhamento foliar de pelo menos 16 horas mostrourse essencial para a infecção, enquanto que períodos mais longos resultaram num aumento no tamanho e número de lesões (Somasundara \& Anilkumar, 1990).

Estudos conduzidos por Islam \& Maric (1980) indicaram que chuvas freqüentes e temperatura moderadamente elevada (entre 24 e $27^{\circ} \mathrm{C}$ ) favorecem a disseminação da doença. Antes do florescimento, a doença aparece esporadicamente e principalmente nas folhas inferiores. Além disso, a idade da planta deve ser considerada 
como um importante fator no desenvolvimento da doença, já que a doença é mais prevalecente e evolui de forma epidêmica quando a planta aproxima-se da senescência.

\subsection{Quantificação de danos}

Estimativas confiáveis dos prejuízos causados pelos patógenos são um pré-requisito para o desenvolvimento de qualquer programa bem sucedido de controle de doenças (Bergamin \& Amorim, 1996).

Qualquer sintoma visível causado por um organismo nocivo (patógenos ou pragas) é coletivamente chamado injúria. O dano é definido como qualquer redução na qualidade ou quantidade da produção que é resultante de uma injúria. A redução em retorno financeiro por unidade de área devida à ação de organismos nocivos é chamada perda (Bergamin Filho, 1995; Bergamin \& Amorim, 1996). Obter dados para estabelecer a função de dano é o objetivo da fase experimental de um projeto de pesquisa que vise a determinação de prejuízos causados por um patógeno. Neste contexto, a injúria pode ser traduzida pela severidade da doença, no caso de patossistemas como girassol - $A$. helianthi. Ensaios que contêm parcelas sadias e parcelas doentes com diferentes níveis de injúria são geralmente empregados para o estabelecimento da função de dano. Deste modo, obtém-se um conjunto de variáveis independentes (níveis de doença), que pode ser relacionado com um conjunto de variáveis dependentes (níveis de dano) (Bergamin \& Amorim, 1996).

A relação entre a severidade da doença e produtividade é freqüentemente resumida a modelos empíricos que descrevem a performance média da cultura na presença do patógeno. Entretanto, seu uso é normalmente limitado às condições específicas nas quais foi desenvolvido e qualquer mudança no sistema de produção invalida essa relação. A alternativa é basear a relação numa análise epidemiológica da população do patógeno e no conceito fisiológico de crescimento e desenvolvimento do hospedeiro (Gaunt, 1995).

De acordo com Waggoner \& Berger (1987), a produção ou matéria seca de uma planta é função, em grande parte, da fotossíntese que ocorre nas folhas. Assim, existe alta correlação entre a produção e o índice de área foliar ("leaf area index" - $L A I$ ), 
que é a relação entre metros quadrados de área foliar por metro quadrado de solo, ou ainda com a duração da área foliar ("leaf area duration" - $L A D$ ), definida como a integral em função do tempo do LAI. Ainda, a fotossíntese está mais diretamente relacionada com a absorção da radiação solar pelas folhas, do que com a área foliar ou com o LAI. Mais correlacionada com a produção está uma variável que leva em conta a quantidade de luz realmente absorvida pela folhagem, que é a absorção da área foliar ("leaf area absorption" - $L A A)$.

Cabe salientar que os fitopatologistas têm concentrado seus estudos no aumento do número de lesões ou no progresso da intensidade de doença com o passar do tempo, como a área sob a curva de progresso da doença ("area under disease progress curve" - AUDPC) e, utilizando esses parâmetros, relacionar danos com o nível de intensidade da doença permanece muito difícil (Bergamin \& Amorim, 1996).

Juntando os efeitos da doença sobre a folhagem da planta hospedeiro, Waggoner \& Berger (1987) afirmam que parece lógico subtrair a área foliar doente da duração da área foliar, o que resulta na duração da área foliar sadia ("health leaf area duration" - $H A D$ ). Na variável absorção da área foliar, a inclusão da área foliar doente produz a absorção da área foliar sadia ("health leaf area absorption" - HAA).

Campbell \& Madden (1990) reconhecem que a determinação de $H A D$ e $H A A$ é muito mais trabalhosa e requer mais tempo que os estudos típicos de danos, onde se considera apenas a intensidade da doença. Estas duas variáveis exigem a determinação real da área foliar durante todo o ciclo da cultura e sua correlação com componentes de produção constituem os modelos integrais.

Modelos de ponto crítico são precisos e acurados para alguns patossistemas. Estes relacionam danos com intensidade da doença numa fase específica de desenvolvimento do hospedeiro, o que exige que a avaliação seja feita apenas nesse ponto (Campbell \& Madden, 1990).

Segundo Vannozzi et al. (1999), o $L A I$ e a integral $L A D$ são características que têm sido freqüentemente correlacionadas com produção de aquênios em girassol, sendo esta última positivamente correlacionada, especialmente após o 
florescimento. Essas variáveis têm sido empregadas em estudos de tolerância a seca em girassol (Miller \& Fick, 1997).

A estimativa do LAI pode ser feita por meio de métodos diretos ou indiretos. No direto, as medidas de área foliar são feitas diretamente na copa da planta e é feita a integração entre a contagem do número de folhas e a estimativa de sua área. No indireto, algumas propriedades da copa, como a transmissão ou a reflectância da luz solar, são relacionados com a área foliar. Esta estimativa pode ser feita com equipamentos modernos, como o analisador de copa (Bergamin \& Amorim, 1996).

O analisador de copa LAI-2000 (LI-COR®, Lincoln, Nebraska, USA) é formado por um sistema portátil de sensores, que consiste de cinco fotodiodos cujas superfícies ativas estão arranjadas em anéis concêntricos. A imagem da visão periférica é projetada nesses anéis, permitindo que cada um proceda a medida da radiação incidente na banda dos ângulos zenitais de 7, 23, 38, 53 e 68 . Um filtro óptico restringe a radiação transmitida a menos de $490 \mathrm{~nm}$, minimizando a contribuição da luz que foi dispersa pela folhagem. Na prática, as frações nos cinco ângulos podem ser medidas por uma leitura de referência sobre a copa (com o sensor direcionado para o céu) e uma ou mais leituras sob a copa (com o sensor novamente direcionado para cima). A relação entre a luz incidente fora da cultura e sob a copa das plantas fornece a transmitância de cada ângulo, que é inversamente proporcional ao LAI. Restritores podem ser usados para limitar a visão azimutal do sensor e, assim, limitar o efeito sombreador do operador (Bergamin \& Amorim, 1996; Welles, 1990; Welles \& Norman, 1991).

\subsubsection{Danos causados pela mancha de Alternaria}

Os danos atribuídos à mancha de Alternaria são variáveis, dependendo da fase em que a planta foi infectada e das condições climáticas prevalecentes.

Reddy \& Gupta (1977) avaliaram a infecção natural de plantas de girassol por A. helianthi, com variação na intensidade da doença. A redução na produtividade variou de 11,3 a 73,3\% e mostrou uma clara relação entre severidade da doença e dano.

Allen et al. (1981) compararam parcelas de girassol inoculadas com $A$. helianthi com uma parcela sadia, onde foi realizado o controle químico. O controle da 
epidemia na antese aumentou o rendimento de óleo em $28 \%$, atribuído ao aumento do número de sementes por capítulo.

Danos na produção de grãos do híbrido 894 da ordem de $51 \%$ foram verificados em Dakota do Sul, EUA, quando as parcelas foram comparadas com a testemunha tratada com fungicida, para controle de A. helianthi. O peso de 100 sementes e o teor de óleo foram significativamente reduzidos (Carson, 1985). Outro estudo realizado por Carson (1987) indicou que a produção de grãos de girassol foi reduzida em $16 \%$ quando as plantas foram inoculadas com A. zinniae na fase de desenvolvimento V6. A produção de grãos, o conteúdo de óleo e o peso de sementes não foram consistentemente correlacionados com as avaliações de severidade da doença e área sob a curva de progresso da doença.

Estudos preliminares realizados no Brasil sobre o desenvolvimento da mancha de Alternaria em girassol em diferentes épocas de semeadura demonstraram que os menores índices de infecção foram sempre observados nas semeaduras dos meses de outubro e novembro. Resultados de uma safra de avaliação indicaram que o inóculo do fungo oriundo das primeiras semeaduras mostrou-se importante na disseminação da doença às plantas das últimas semeaduras (Carvalho et al., 1995).

Epidemias da mancha de Alternaria em girassol, na Índia, em experimentos conduzidos entre 1991 a 1995, com infecção em diferentes fases de desenvolvimento da planta, provocaram danos na produção de até $61,9 \%$, com redução no número de aquênios por capítulo e peso de grãos. A equação de regressão entre produtividade e severidade da doença (\%) resultou em valores de coeficiente de determinação variando entre 0,88 e 0,96. A infecção ocorrida entre o final da fase vegetativa e a emissão do botão floral resultou em maiores danos à produtividade (Chattopadhyay, 1999; Srinivas et al., 1998). 


\section{ELABORAÇÃO E VALIDAÇÃo DE ESCALA DIAGRAMÁTICA PARA MANCHA DE ALTERNARIA EM GIRASSOL}

\section{Resumo}

Uma escala diagramática para avaliação da mancha de Alternaria, causada por Alternaria helianthi, em girassol foi desenvolvida. A escala considerou os limites de severidade mínima e máxima da doença observados no campo e os níveis intermediários seguiram incrementos logarítmicos, representando: 0,$03 ; 0,2 ; 0,6 ; 3 ; 7$; $12 ; 25 ; 40$ e $66 \%$ da área foliar lesionada. A escala foi validada por três avaliadores experientes, que utilizaram 50 folhas com diferentes níveis de severidade, em duas etapas. Na primeira etapa, as folhas foram desenhadas e na segunda, foram utilizadas folhas verdes recém-coletadas no campo. Regressões lineares entre severidades real e estimada foram calculadas. A escala permitiu que se fizesse uma avaliação acurada (intercepto da regressão linear entre severidades real e estimada igual a 0 e coeficiente angular da reta próximo a 1) e precisa (coeficiente de determinação próximo a 100\%), para a média dos avaliadores, quando se utilizou folhas desenhadas. Quando foram utilizadas folhas verdes com sintomas, a acurácia diminuiu, apesar da precisão manter-se em padrões aceitáveis $\left(R^{2}=0,95\right)$. Mesmo assim, o erro absoluto ao estimar a severidade, para os três avaliadores, foi menor que $13 \%$, tanto para folhas desenhadas quanto para folhas verdes. A reprodutibilidade das avaliações, calculada pelo coeficiente de determinação das regressões lineares entre as severidades estimadas pelos três avaliadores, foi alta $\left(R^{2}>0,86\right)$, para todas as situações. A escala mostrourse adequada para avaliações da severidade da mancha de Alternaria e está sendo utilizada para avaliar a severidade de doença em girassol, em experimentos de campo e de câmara de crescimento de plantas. 


\section{Development and validation of a diagrammatic scale for Alternaria leaf spot of sunflower}

\section{Summary}

A diagrammatic scale for Alternaria leaf spot, caused by Alternaria helianthi, in sunflower was developed, considering the lowest and highest limits of severity observed in the field. Intermediate levels followed logarithmic increments, representing: $0.03 ; 0.2 ; 0.6 ; 3 ; 7 ; 12 ; 25 ; 40$; and $66 \%$ of diseased leaf area. The scale was validated by three experienced raters, who utilized 50 leaves with different levels of severity, in two stages: in the first, leaves were drawn and in the second, diseased leaves recently collected from the field were used. Regression lines between actual and

estimated severity were calculated. The scale permitted assessments to be accurate (intercepts of regression lines between actual and estimated severity not different from 0 and angular coefficients close to 1) and precise (coefficient of determination close to $100 \%)$, for the average of raters, when drawn leaves were used. The accuracy was lower for detached leaves than for drawn leaves, but precision was high $\left(R^{2}=0.95\right)$. Even so, absolute error in estimating disease severity was lower than $13 \%$, for both drawn and detached leaves. The reproducibility of assessments, estimated by the coefficient of determination of regression lines between estimates of severity of the three raters was high $\left(R^{2}>0.86\right)$, for all situations. The scale proved to be adequate for assessments of severity of Alternaria leaf spot and has been utilized to assess disease severity in sunflower, in the field as well as in controlled environment experiments.

\subsection{Introdução}

Estudos epidemiológicos de doenças de plantas requerem métodos de quantificação confiáveis, precisos e que apresentem resultados facilmente reproduzíveis. Quando a incidência (número, proporção ou porcentagem de plantas ou parte de plantas doentes na amostra ou população de plantas) (Bergamin Filho \& Amorim, 1996; 
Campbell \& Madden, 1990; James, 1974; Kranz, 1988) não pode ser usada para quantificar doenças foliares, a severidade (valores absolutos, proporção ou porcentagem da área ou volume de tecido da planta coberto por sintomas) (Bergamin Filho \& Amorim, 1996; Kranz, 1988) é a variável mais utilizada (Gaunt, 1995).

A severidade de doenças é geralmente estimada visualmente. Para auxiliar o avaliador e minimizar a subjetividade da estimativa, escalas diagramáticas têm sido uma ferramenta bastante útil. Uma escala diagramática é a representação ilustrada de uma série de plantas, ou partes de plantas, com sintomas em diferentes níveis de severidade da doença (Bergamin Filho \& Amorim, 1996). As escalas diagramáticas são de fácil utilização, aplicáveis a uma ampla gama de condições diferentes com resultados reproduzíveis e permitem avaliação rápida (Berger, 1980). No preparo dessas escalas, alguns aspectos devem ser considerados: a) os limites inferior e superior da escala devem corresponder, respectivamente, às quantidades de doença mínima e máxima encontradas no campo; b) a representação dos sintomas deve ser próxima do observado na planta; c) os níveis intermediários devem seguir as limitações da acuidade visual humana, definidas pela "lei de estímulo-resposta de Weber-Fechner", que diz ser "a acuidade visual proporcional ao logaritmo da intensidade do estímulo"; e d) a vista humana visualiza tecido doente para níveis de severidade abaixo de $50 \%$ e tecido sadio para níveis de severidade superiores a 50\% (Bergamin Filho \& Amorim, 1996; Horsfall \& Barratt, 1945; James, 1974; Nutter Jr. \& Schultz, 1995).

Além das recomendações no seu preparo, o sucesso do uso de escalas diagramáticas, medido pelas precisão e acurácia na estimativa da severidade da doença, depende da experiência e da percepção individual de cada avaliador. Antes que uma escala seja utilizada como um método de avaliação padrão, ela deve ser validada por avaliadores experientes e, em caso de resultados insatisfatórios, deve ser corrigida (Nutter Jr. \& Schultz, 1995). A baixa distribuição de níveis intermediários pode levar, por exemplo, a alta variabilidade em estimar um específico intervalo de severidade. Nesse caso, níveis adicionais devem ser incluídos na escala, para orientar o avaliador (Amorim et al., 1993). 
A mancha de Alternaria, causada por Alternaria helianthi (Hansf.) Tubaki \& Nishihara, é uma das principais doenças do girassol no Brasil. Os sintomas iniciais típicos nas folhas são pequenas pontuações necróticas com cerca de 3 a 5 mm de diâmetro, de coloração variável da castanha à negra, de formato arredondado a angular, com halo clorótico. As lesões características apresentam círculos concêntricos, semelhantes a um alvo. Essas lesões podem coalescer, formando áreas extensas de tecido necrosado, provocando a seca prematura da folha e, conseqüentemente, a desfolha precoce das plantas (Leite, 1997).

A avaliação da severidade da mancha de Alternaria em girassol tem sido feita de diferentes maneiras, como, por exemplo, usando chaves diagramáticas. Carson (1985), em estudos de danos associados com a mancha de Alternaria, utilizou a escala de Horsfall \& Barratt (1945) para avaliar a porcentagem de área foliar infectada, em plantas de girassol inoculadas artificialmente. Godoy \& Fernandes (1985b) utilizaram uma escala de notas variando de 1 a 5, para a avaliação da severidade da mancha de Alternaria em ensaios de campo, usando uma figura com diferentes níveis de severidade, porém sem identificar tais níveis. Não há referência sobre validação ou treinamento de avaliadores com as referidas escalas.

Outros autores têm utilizado chaves descritivas, que utilizam escalas arbitrárias com certo número de graus para quantificar doenças, as quais encontram grande aceitação entre pesquisadores (Bergamin Filho \& Amorim, 1996). Para a mancha de Alternaria, essas chaves têm variado muito quanto ao número de níveis, bem como quanto à descrição de cada nível. Em estudos abordando o efeito de controle químico, a influência da época de semeadura, a suscetibilidade de plantas de girassol de diferentes idades e a reação de genótipos, a severidade da doença tem sido avaliada utilizando uma chave descritiva com níveis variando de 0 a 5, onde cada nível representa um intervalo diferente de severidade, dependendo da escala (Balasubrahmanyam \& Kolte, 1980; Leite et al., 1999; Sahu et al., 1991; Sirry et al., 1978; Soto et al., 1990). Nagaraju et al. (1992), Ravikumar et al. (1995), Salam (1994) e Velazhahan et al. (1991), avaliando a resistência de genótipos de girassol, utilizaram chaves que descrevem seis níveis de 0 a 9, considerando apenas os números ímpares, além do zero, que são relacionados com 
intervalos de porcentagem de área foliar doente. Apesar do amplo uso, essas formas apresentam deficiências, pois, além de não haver padronização para a descrição dos níveis, que normalmente têm incrementos aritméticos, cada nível abrange um intervalo, não permitindo interpolação.

Na tentativa de padronizar métodos de inoculação artificial e de avaliação de doenças de girassol, o grupo de trabalho denominado "Studies on common methodologies of artificial inoculation and population dynamics of sunflower pathogens", incluído na "FAO European Research Network on Sunflower", recomenda o uso de uma escala de 0 a 9, relacionada a sistema numérico que considera a severidade, em intervalos de $0,1-11 \%, 12-22 \%, 23-33 \%, 34-44 \%, 45-55 \%, 56-66 \%, 67-$ $77 \%, 78-88 \%$ e $89-100 \%$. O grupo indica que a porcentagem da área foliar lesionada seja determinada por exame visual de cada folha (Masirevic, 1995). Esse método também apresenta deficiências no sentido de desconsiderar os incrementos logarítmicos de severidade, perceptíveis pela visão humana, além de não ter sido validado.

Assim, verifica-se a necessidade de estabelecer um método mais adequado que oriente a avaliação da severidade da mancha de Alternaria em folhas de girassol, de modo a torná-la padronizada e menos sujeita a subjetividade. Para isso, o objetivo do presente trabalho foi desenvolver e validar uma escala diagramática para avaliação da mancha de Alternaria em girassol.

\subsection{Material e Métodos}

A escala desenvolvida neste estudo foi desenhada considerando os limites de severidade mínima e máxima da mancha de Alternaria observados no campo. Para quantificar esses níveis, 50 folhas do híbrido experimental de girassol SE01, desenvolvido pela Embrapa Soja, com ampla variação de severidade da doença, coletadas no campo, foram reproduzidas em plástico transparente e em folha de papel. A área foliar total e a área doente foram quantificadas por um medidor de área foliar (LICOR ${ }^{\circledR}$ LI-3000), utilizando, respectivamente, as folhas desenhadas em papel e a área lesionada desenhada no plástico. Para correlacionar a área foliar total com uma variável 
de fácil mensuração, também foram medidos a maior largura e o comprimento das 50 folhas. Os níveis intermediários da escala foram determinados matematicamente, seguindo incrementos logarítmicos.

Uma vez que as porcentagens de doença a serem representadas na escala foram estabelecidas, um desenho padrão com área conhecida representando uma folha de girassol foi reproduzido, ao qual foram acrescentados círculos, com diâmetros variáveis, distribuídos de maneira a reproduzir os sintomas das folhas coletadas no campo, incluindo lesões necróticas e halo clorótico, para representar os níveis de severidade determinados.

Para validação da escala, três avaliadores experientes, denominados avaliador 1, 2 e 3, utilizaram 50 folhas com diferentes níveis de severidade, em duas etapas. Na primeira etapa, as folhas foram desenhadas e na segunda, foram utilizadas folhas verdes recém-coletadas no campo. As áreas foliares total e lesionada de cada folha foram quantificadas com medidor de área foliar total, da mesma maneira descrita anteriormente, para calcular a severidade real. A escala diagramática foi utilizada como guia para estimar a severidade pelos avaliadores, usando interpolação entre os níveis.

Regressões lineares entre severidades real (variável independente) e estimada (variável dependente) foram calculadas, de acordo com a metodologia de Draper \& Smith (1998) e Teng (1981). A acurácia das estimativas de cada avaliador foi determinada pelo teste t aplicado ao intercepto da regressão linear (a), para verificar se foi significativamente diferente de 0 , e ao coeficiente angular da reta $(b)$, para testar se foi significativamente diferente de 1 , ao nível de probabilidade $p=0,01$. A precisão foi estimada pelo coeficiente de determinação da regressão e pela variação dos erros absolutos (severidade estimada menos real) (Campbell \& Madden, 1990; Kranz, 1988; Nutter Jr. \& Schultz, 1995). A reprodutibilidade da escala foi avaliada pelos coeficientes de determinação das regressões lineares entre as severidades estimadas dos diferentes avaliadores, combinados em pares, como proposto por Nutter Jr. \& Schultz (1995) e Nutter Jr. et al. (1993). O programa Microsoft Excel 97 (Microsoft Corporation, 1997) foi utilizado nas análises de regressão linear. 


\subsection{Resultados e Discussão}

Visando correlacionar a área foliar de girassol com uma variável de fácil leitura em condições de campo, a regressão linear entre as medidas de área foliar total e de maior largura de 50 folhas do híbrido de girassol SE01 resultou num coeficiente de determinação elevado, de 0,90 (Tabela 1). Isto permitiu definir a equação: $Y=-155,86+$ 22,40 X, onde $Y$ é a área foliar de girassol $\left(\mathrm{em}^{2}{ }^{2}\right)$ e $X$ é a maior largura da folha (em $\mathrm{cm})$.

Tabela 1. Intercepto $(a)$, coeficiente angular $(b)$ e coeficiente de determinação $\left(R^{2}\right)$ das regressões lineares entre área foliar e variáveis foliares, para 50 folhas de girassol.

\begin{tabular}{lrrr}
\hline Variável foliar & \multicolumn{1}{c}{$\boldsymbol{c}$} & $\boldsymbol{b}$ & $\boldsymbol{R}^{\mathbf{2}}$ \\
\hline Maior largura & $-155,86$ & 22,40 & 0,90 \\
Comprimento & $-154,85$ & 20,86 & 0,65 \\
Largura x comprimento & 14,41 & 1,31 & 0,90 \\
\hline
\end{tabular}

Esta variável pode ser utilizada em avaliações onde se pretende estimar a

área foliar total, o que está de acordo com Pereyra et al. (1978), que também considerou que a largura isoladamente pode ser considerada a melhor variável para se correlacionar com a área foliar do girassol. Entretanto, esses autores sugerem que sejam utilizadas duas diferentes equações, uma para folhas com largura até $21 \mathrm{~cm}$ e outra para folhas com largura maior que $21 \mathrm{~cm}$. No presente trabalho, a largura mínima da folha para a estimativa de sua área deve ser de $8 \mathrm{~cm}$. Schneiter (1978) obteve uma equação que correlaciona o produto comprimento x largura com a área foliar, mas esse método é mais trabalhoso, já que requer também a avaliação do comprimento foliar, além da largura. Neste trabalho, o uso das duas variáveis não aumentou a precisão da estimativa realizada usando apenas a largura (Tabela 1). 
A escala diagramática elaborada para mancha de Alternaria em girassol representou: 0,$03 ; 0,2 ; 0,6 ; 3 ; 7 ; 12 ; 25 ; 40$ e $66 \%$ da área foliar lesionada (Figura 1). A representação dos sintomas incluiu o tecido necrosado resultante da ação do patógeno em lesões individuais, e lesões coalescidas nos níveis de severidade a partir de $12 \%$. A coalescência de lesões é característica da doença, que pode formar extensas áreas de tecido necrosado na folha (Leite, 1997). Valores acima de $60 \%$ são raramente encontrados no campo, já que folhas com esse nível de severidade sofrem senescência rápida e seca prematura.

O incremento logarítmico dos níveis de severidade é uma das características na elaboração de escalas diagramáticas responsáveis pela facilidade em interpolar estimativas de severidade (Godoy et al., 1997). Escalas que representam incrementos logarítmicos são freqüentemente denominadas como escala de Horsfall \& Barratt, que utilizam a lei de acuidade visual de Weber-Fechner (Horsfall \& Barratt, 1945). Entretanto, alguns fitopatologistas hesitam em utilizar escalas com amplos intervalos entre as severidades representadas, como por exemplo apenas dois níveis entre 25 e 75\% de severidade da doença (Campbell \& Madden, 1990). Assim, esses níveis podem ser subdivididos em intervalos menores, como já proposto por Amorim et al. (1993), Berger (1980) e Godoy et al. (1997), o que também foi feito neste trabalho. É conveniente salientar que as escalas diagramáticas devem seguir incrementos logarítmicos, sem necessariamente utilizar os intervalos definidos por Horsfall \& Barratt (1945).

A acurácia, definida como a exatidão de uma medida isenta de erros sistemáticos (Bergamin Filho \& Amorim, 1996), pode ser medida pelo coeficiente angular e intercepto da regressão linear entre severidades real e estimada. As avaliações acuradas mostram proximidade entre a estimativa e a realidade. Assim, a inclinação da regressão linear entre valores reais e estimados deve ser igual a 1, sem desvios sistemáticos, e o intercepto deve ser igual a 0 (Nutter Jr. et al., 1993). 


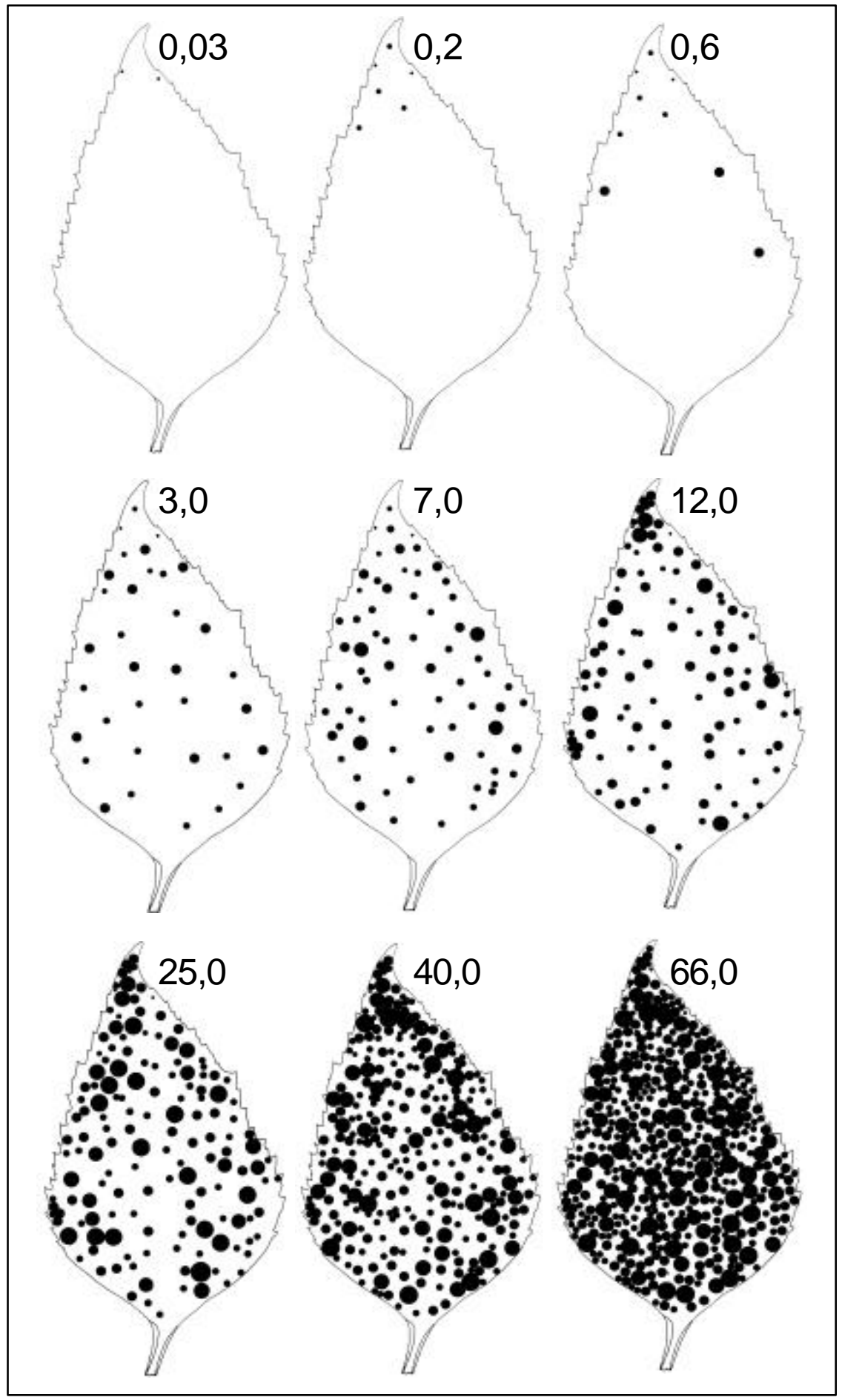

Figura 1 - Escala diagramática para avaliação da mancha de Alternaria em girassol. Valores em porcentagem da área foliar com sintomas (lesões necróticas e halo clorótico). 
A escala desenvolvida neste trabalho permitiu que se fizesse uma avaliação acurada (intercepto da regressão linear entre severidades real e estimada igual a 0 e coeficiente angular da reta próximo a 1), para a média dos avaliadores, quando se utilizou folhas desenhadas (Figura 2 e Tabela 2). Para essas folhas, as avaliações dos avaliadores 2 e 3 apresentaram coeficientes angulares diferentes de 1, a $p=0,01$, mas mesmo assim próximos de 1 , enquanto que os interceptos para os três avaliadores foram iguais a 0 (Tabela 2 e Apêndice 1).

Quando foram utilizadas folhas verdes com sintomas, a acurácia diminuiu para a média dos avaliadores e para cada avaliador individualmente. Essa alteração pode ser atribuída à maior dificuldade dos avaliadores em compararem a versão preta e branca da escala com as cores presentes nas folhas doentes. Os resultados indicam que houve superestimativa da severidade da doença, já que os coeficientes angulares das regressões lineares entre severidades real e estimada foram significativamente maiores do que 1 , para os avaliadores 1 e 2 e para a média (Tabela 2 e Apêndice 1).
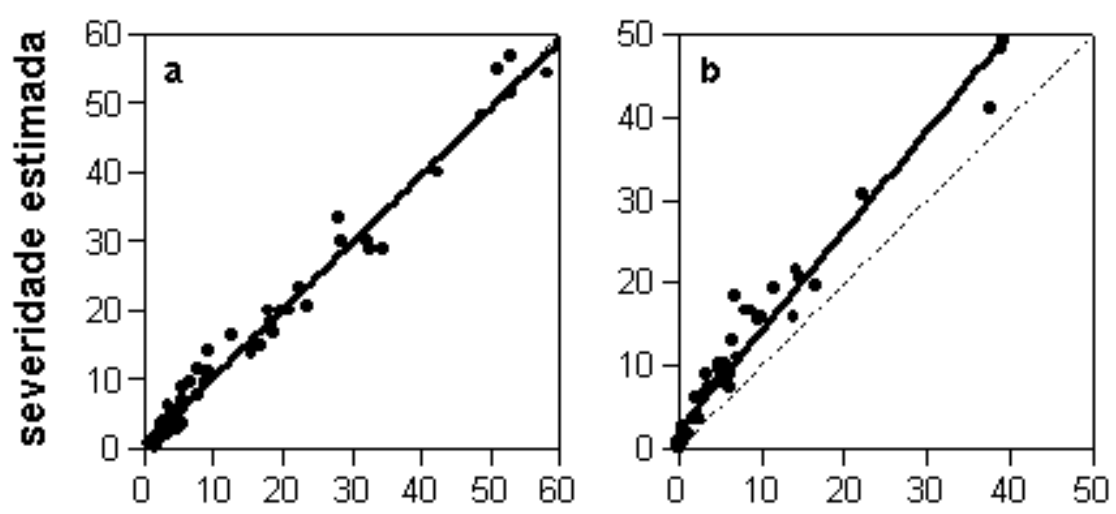

severidade real

Figura 2 - Regressões lineares (linha contínua) entre severidades real e estimada, para a média dos avaliadores, quando foram utilizadas folhas desenhadas (a) ou folhas verdes com sintomas (b). Pontos representam a média de 50 estimativas de cada avaliador. A linha tracejada representa a situação ideal em que a severidade estimada é idêntica à real. 
Tabela 2. Intercepto $(a)$, coeficiente angular $(b)$ e coeficiente de determinação $\left(R^{2}\right)$ das regressões lineares entre severidades real e estimada, para os três avaliadores, com amostras desenhadas (folhas desenhadas) ou reais (folhas verdes com sintomas.

\begin{tabular}{|c|c|c|c|}
\hline Avaliações & $a$ & $b$ & $R^{2}$ \\
\hline \multicolumn{4}{|l|}{ Folhas desenhadas } \\
\hline Avaliador 1 & 1,77 & 0,89 & 0,91 \\
\hline Avaliador 2 & 0,16 & $1,11^{*}$ & 0,95 \\
\hline Avaliador 3 & $-0,19$ & $0,90 *$ & 0,95 \\
\hline Médias dos avaliadores & 0,58 & 0,97 & 0,97 \\
\hline \multicolumn{4}{|l|}{ Folhas verdes com sintomas } \\
\hline Avaliador 1 & 1,03 & $1,18^{*}$ & 0,95 \\
\hline Avaliador 2 & $2,18 *$ & $1,29 *$ & 0,94 \\
\hline Avaliador 3 & $2,97 *$ & 1,14 & 0,90 \\
\hline Médias dos avaliadores & $2,06 *$ & $1,20 *$ & 0,95 \\
\hline
\end{tabular}

A precisão, definida como a exatidão de uma operação onde há rigor ou refinamento na medida (Bergamin Filho \& Amorim, 1996), pode ser avaliada pelo coeficiente de determinação da regressão, que deve ser próximo de $100 \%$, e pela variação dos erros absolutos (diferenças entre severidades estimada e real) (Nutter Jr. \& Schultz, 1995).

A utilização da escala desenvolvida para mancha de Alternaria conferiu alta precisão (coeficiente de determinação próximo a 100\%), para os três avaliadores e para a média, quando se utilizou folhas desenhadas (Figura 2, Tabela 2 e Apêndice 1). A menor precisão foi obtida pelo avaliador $1\left(R^{2}=0,91\right)$. Quando foram utilizadas folhas verdes com sintomas, a precisão manteve-se em padrões aceitáveis para a média dos avaliadores $\left(R^{2}=0,95\right)$ e até aumentou para o avaliador 1 (Figura 2 e Tabela 2$)$. 
Além do coeficiente de determinação, a precisão foi medida pelos erros absolutos, que são as diferenças entre as severidades estimada e real (Nutter Jr. \& Schultz, 1995). O erro absoluto ao estimar a severidade, para os três avaliadores, foi menor que 13\%, tanto para folhas desenhadas quanto para folhas verdes (Figura 3). Como já verificado na avaliação da acurácia, ao utilizar folhas verdes com sintomas, os avaliadores superestimaram a severidade da doença, o que foi confirmado pelos erros absolutos (Figura 3). As soluções para corrigir essa superestimativa da doença variam de acordo com a magnitude do erro, mas passam por maior treinamento dos avaliadores (Godoy et al., 1997; Nutter Jr. \& Schultz, 1995).
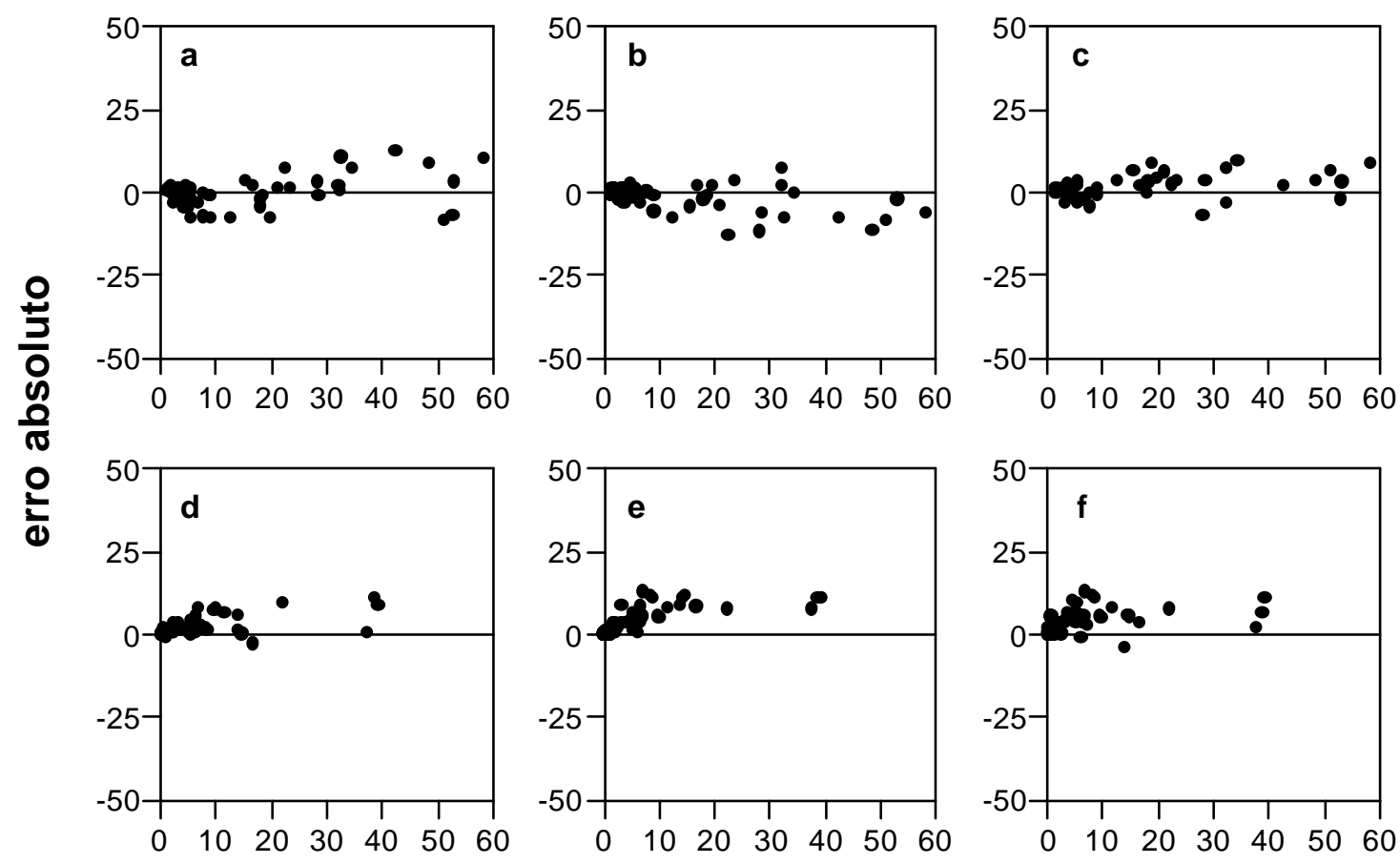

severidade real

Figura 3 - Erros absolutos (diferenças entre severidades estimada e real) dos avaliadores 1 (a, d), 2 (b, e) e 3 (c, f), quando foram utilizadas folhas desenhadas $(a, b, c)$ ou folhas verdes com sintomas (d, e, f). Pontos representam 50 estimativas de cada avaliador. 
A reprodutibilidade das avaliações entre os avaliadores, combinados em pares, também pode ser utilizada como um indicativo de precisão de um método de avaliação de doenças (Nutter Jr. \& Schultz, 1995). As regressões lineares entre as severidades estimadas pelos três avaliadores produziram coeficientes de determinação altos $\left(R^{2}>0,86\right)$, para todas as situações, bem como coeficientes angulares próximos a 1 , para a maioria das combinações, principalmente para as avaliações utilizando folhas verdes com sintomas (Tabela 3 e Apêndice 2). Assim, os dados coletados pelos diferentes avaliadores estão próximos de uma concordância perfeita, o que indica alta precisão (Nutter Jr. \& Schultz, 1995).

Tabela 3. Intercepto (a), coeficiente angular $(b)$ e coeficiente de determinação $\left(R^{2}\right)$ das regressões lineares entre severidades estimadas dos diferentes avaliadores, com amostras desenhadas (folhas desenhadas) ou reais (folhas verdes com sintomas.

\begin{tabular}{rccc}
\hline Avaliações & $\boldsymbol{a}$ & $\boldsymbol{b}$ & $\boldsymbol{R}^{\mathbf{2}}$ \\
\hline Folhas desenhadas & & & \\
Avaliador 1 x Avaliador 2 & 2,33 & $0,76^{*}$ & 0,86 \\
Avaliador 1 x Avaliador 3 & 2,36 & 0,95 & 0,90 \\
Avaliador 2 x Avaliador 3 & 1,10 & $1,17 *$ & 0,92 \\
Folhas verdes com sintomas & & & \\
Avaliador 1 x Avaliador 2 & $-0,51$ & $0,87 *$ & 0,92 \\
Avaliador 1 x Avaliador 3 & $-1,21$ & 0,95 & 0,90 \\
Avaliador 2 x Avaliador 3 & $-0,50$ & 1,07 & 0,92 \\
\hline asterisco representa situações onde a hipótese de nulidade $(a=0$ ou $b=1)$ foi rejeitada pelo teste $\mathrm{t}, p<0,01$.
\end{tabular}

A proposta de estabelecer um sistema padronizado para orientar a avaliação da mancha de Alternaria em folhas de girassol é de grande responsabilidade, já que, se o sistema for deficiente, o custo de sua utilização pode ser maior do que os 
benefícios alcançados com seu uso (Nutter Jr. \& Schultz, 1995). Mesmo assim, a padronização é altamente desejável, já que a uniformidade de metodologia de avaliação de doenças torna comparáveis os resultados obtidos em experimentos de instituições públicas e privadas em diferentes localidades (Bergamin Filho \& Amorim, 1996). De

qualquer forma, a escala proposta no presente trabalho mostrou-se adequada para avaliações da severidade da mancha de Alternaria no campo e em condições controladas e está sendo utilizada para elaboração de curvas de progresso da doença, estudos de componentes monocíclicos e determinação de danos na cultura do girassol. Uma cópia da escala está sendo submetida ao grupo de trabalho "Studies on common methodologies of artificial inoculation and population dynamics of sunflower pathogens", incluído na "FAO European Research Network on Sunflower", para apreciação e adoção em trabalhos de pesquisa com mancha de Alternaria de girassol.

\subsection{Conclusões}

A escala diagramática para mancha de Alternaria elaborada e validada neste trabalho pode ser utilizada para estimar a severidade da doença, em experimentos de girassol, com alta precisão. 


\section{INFLUÊNCIA DA TEMPERATURA E DA DURAÇÃO DO PERÍODO DE MOLHAMENTO FOLIAR NO MONOCICLO DA MANCHA DE ALTERNARIA EM GIRASSOL}

\section{Resumo}

A influência da temperatura $\left(15^{\circ} \mathrm{C}-32,5^{\circ} \mathrm{C}\right)$ e da duração do período de molhamento foliar $(2 \mathrm{~h}-24 \mathrm{~h})$ no desenvolvimento da mancha de Alternaria em girassol (Alternaria helianthi) foi quantificada por meio de estudos em ambiente controlado. Também foi verificada a influência da temperatura no crescimento micelial e na germinação de conídios do fungo, em ensaios in vitro. A densidade relativa de lesões e a severidade foram influenciadas pela temperatura e pela duração do período de molhamento foliar. A doença foi mais severa na temperatura de $25{ }^{\circ} \mathrm{C}$. A temperatura mínima para desenvolvimento da doença, estimada pela função beta generalizada, foi de $13,0{ }^{\circ} \mathrm{C}$ e a máxima foi de $35,8{ }^{\circ} \mathrm{C}$. A densidade relativa de lesões foi maior com o aumento da duração do período de molhamento foliar, o que foi descrito pelo modelo logístico. A superfície de resposta obtida pela multiplicação das funções beta generalizada e logística teve um bom ajuste para os dados observados $\left(R^{2}=0,87\right.$ para densidade relativa de lesões e 0,92 para severidade). O crescimento micelial e a germinação de conídios em função da temperatura também foram descritos pela função beta generalizada. As temperaturas mínimas estimadas para a taxa de crescimento micelial e para a germinação de conídios foram de $5,5{ }^{\circ} \mathrm{C}$ e $7,9{ }^{\circ} \mathrm{C}$ e as máximas foram de $32,9{ }^{\circ} \mathrm{C}$ e $40,0{ }^{\circ} \mathrm{C}$, respectivamente. $\mathrm{Na}$ avaliação de 10 híbridos de girassol inoculados artificialmente, em condições controladas, houve diferença entre os materiais quanto à resistência à infecção e à colonização por A. helianthi. 


\section{Influence of temperature and leaf wetness on the monocycle of Alternaria leaf spot of sunflower}

\section{Summary}

The influence of temperature $\left(15^{\circ} \mathrm{C}-32.5^{\circ} \mathrm{C}\right)$ and leaf wetness duration ( $2 \mathrm{~h}-24 \mathrm{~h}$ ) on the development of Alternaria leaf spot, caused by Alternaria helianthi in sunflower, was quantified under controlled environment. The effect of temperature on the mycelial growth rate and conidia germination was also quantified by in vitro trials. Relative lesion density and disease severity were influenced by temperature and leaf wetness duration. The disease was more severe in the temperature of $25{ }^{\circ} \mathrm{C}$. The minimum temperature for disease development, estimated by generalized beta function, was $13.0^{\circ} \mathrm{C}$ and the maximum was $35.8{ }^{\circ} \mathrm{C}$. The relative lesion density increased with increasing periods of leaf wetness, which was described by logistic model. The response surface obtained by the combination of the generalized beta and logistic functions provided a close fit to observed data $\left(R^{2}=0.87\right.$ for relative lesion density and 0.92 for severity). The generalized beta function also described fungi growth and conidia germination as a function of the temperature. The estimated minimum temperatures for mycelial growth rate and for conidia germination were $5.5{ }^{\circ} \mathrm{C}$ and $7.9{ }^{\circ} \mathrm{C}$, and the maximum were $32.9{ }^{\circ} \mathrm{C}$ and $40.0{ }^{\circ} \mathrm{C}$, respectively. Among 10 sunflower hybrids artificially inoculated, under controlled conditions, differences were observed for resistance to infection and colonization by $A$. helianthi.

\subsection{Introdução}

O girassol (Helianthus annuus L.) é uma dicotiledônea anual, originária do continente Norte Americano, que apresenta características agronômicas importantes, como maior resistência à seca, ao frio e ao calor. Apresenta ampla adaptabilidade às diferentes condições edafoclimáticas e seu rendimento é pouco influenciado pela latitude, pela altitude e pelo fotoperíodo. Graças a essas características, apresenta-se 
como opção nos sistemas de rotação e sucessão de culturas nas regiões produtoras de grãos no Brasil (Castro et al., 1996).

O potencial do aumento da área cultivada com girassol pode ser limitado pela ocorrência da mancha de Alternaria, causada por Alternaria helianthi (Hansf.) Tubaki \& Nishihara. Os danos causados pela diminuição da área fotossintética da planta, devido à formação de manchas foliares e à desfol ha precoce, resultam na redução do diâmetro dos capítulos, do número de aquênios por capítulo, do peso dos aquênios e do teor de óleo. Plantas severamente afetadas apresentam a maturação antecipada. Além do Brasil (Ribeiro et al., 1974), a doença ocorre em países da América do Norte e da África, Argentina, Índia, Japão, Austrália, antiga Iugoslávia, Romênia e França (Anahosur, 1978; Davet et al., 1991; Pereyra \& Escande, 1994; Zimmer \& Hoes, 1978). Em áreas de clima subtropical úmido, condição predominante nas regiões de cultivo de girassol no Brasil, a mancha de Alternaria é uma das principais doenças, ocorrendo em praticamente todas as regiões e em todas as épocas de semeadura (Leite, 1997).

O conhecimento das condições que favorecem o desenvolvimento do fungo e das variáveis climáticas ótimas para infecção e desenvolvimento da doença é fundamental para se delimitar estratégias de controle, que incluem a escolha da época de semeadura da cultura para cada região de cultivo.

Os objetivos deste estudo foram determinar a influência da temperatura e da duração do período de molhamento foliar no desenvolvimento da mancha de Alternaria, sob condições controladas; o efeito da temperatura na taxa de crescimento micelial e na germinação de conídios de A. helianthi e a reação de 10 híbridos de girassol à resistência à infecção e à colonização por $A$. helianthi.

\subsection{Material e Métodos}

Os experimentos foram realizados nas dependências do Laboratório de Epidemiologia, do Departamento de Entomologia, Fitopatologia e Zoologia Agrícola da Escola Superior de Agricultura "Luiz de Queiroz”, em Piracicaba, SP. 
O isolado utilizado foi obtido a partir de folhas de girassol com lesões de mancha de Alternaria, coletadas no campo experimental da Embrapa Soja, em Londrina, PR. O isolamento foi realizado retirando-se fragmentos da região limítrofe entre o tecido sadio e o doente, que foram colocados em placas de Petri contendo meio de cultura farinha de aveia (Tuite, 1969) e incubadas a $25^{\circ} \mathrm{C}$. Os conídios produzidos nesse meio de cultura foram visualizados em microscópio óptico, para confirmação da espécie de Alternaria. A patogenicidade do isolado de A. helianthi foi confirmada, inoculando-se uma suspensão de conídios do isolado, em plantas de girassol do híbrido experimental da Embrapa Soja SE 02, em casa de vegetação. Para conservação do isolado, utilizourse discos de meio de farinha de aveia com micélio do fungo em tubos contendo água destilada esterilizada, que foram vedados com filme plástico e armazenados em geladeira, a $4{ }^{\circ} \mathrm{C}$.

Os ensaios para avaliação do efeito da temperatura e da duração do período de molhamento foliar nos componentes monocíclicos da mancha de Alternaria foram conduzidos em câmaras de crescimento Conviron, modelo E7. Utilizourse plantas de girassol do híbrido SE 02, cultivadas por três semanas em vasos de alumínio com capacidade para 1,5 l, em condições de casa de vegetação. Foram semeadas três sementes por vaso, em solo previamente autoclavado. Após a emergência, procedeu-se um desbaste, restando apenas uma planta por vaso.

No preparo da suspensão de inóculo, o isolado de A. helianthi foi repicado para meio de farinha de aveia, onde foi cultivado por 7-10 dias a $25{ }^{\circ} \mathrm{C}$, sob iluminação contínua. Os conídios foram suspensos, com um pincel, em água destilada + Tween 20 e sua concentração ajustada para 500 conídios $/ \mathrm{ml}$, com auxílio de hemocitômetro.

As plantas foram inoculadas com a suspensão de conídios, nas terceira e quarta folhas verdadeiras, na fase V8 (Schneiter \& Miller, 1981), como recomendado por Kong et al. (1995). A inoculação foi feita com pulverizador manual, utilizando-se 4 $\mathrm{ml}$ de suspensão por folha, de modo que estas ficassem uniformemente molhadas, tanto na face superior como na inferior, até o ponto de escorrimento superficial. Os vasos 
foram envolvidos por sacos plásticos transparentes e umedecidos, de modo a formar uma câmara úmida, e foram colocados nas câmaras de crescimento, no escuro por $24 \mathrm{~h}$.

Para avaliar o efeito da temperatura, as plantas inoculadas foram mantidas sob temperaturas constantes de $15{ }^{\circ} \mathrm{C}, 20{ }^{\circ} \mathrm{C}, 25{ }^{\circ} \mathrm{C}, 27,5{ }^{\circ} \mathrm{C}, 30{ }^{\circ} \mathrm{C}$ e $32,5{ }^{\circ} \mathrm{C}$ e fotoperíodo de $12 \mathrm{~h}$. Após 24 h de câmara úmida, as plantas foram mantidas em câmaras de crescimento, com umidade relativa do ar que variou entre $40 \%$ e $60 \%$. Para cada temperatura, foram conduzidos pelo menos dois ensaios, com delineamento experimental inteiramente casualizado, com cinco repetições. Cada repetição foi composta por um vaso contendo uma planta, onde as duas folhas inoculadas foram avaliadas. Plantas inoculadas com água destilada + Tween 20 foram incubadas em cada temperatura, servindo como controle. A partir da retirada da câmara úmida, as avaliações foram realizadas diariamente, por meio da contagem do número de lesões por folha inoculada, da medição do tamanho médio das lesões e da severidade da doença, com o auxílio de uma escala diagramática (Leite \& Amorim, 2002), até a estabilização dos dados. Para a comparação dos dados entre os ensaios, o número de lesões por folha foi transformado em densidade relativa de lesões, igualando o número máximo a $100 \%$ e calculando os demais valores proporcionalmente ao máximo. Calculou-se a média da densidade relativa de lesões e da severidade das 10 folhas avaliadas para cada temperatura, em cada ensaio. Os dados foram analisados por meio de regressões nãolineares, utilizando o programa STATISTICA versão 5.0 (Statsoft, Tulsa, EUA). Os dados da densidade relativa de lesões durante 8 dias e da severidade da doença durante 21 dias foram ajustados individualmente pelo modelo logístico, $Y=B_{1} /\left(1+B_{2} \exp \left(-B_{3} X\right)\right)$, onde $Y=$ densidade relativa de lesões ou severidade, $X=$ tempo (em dias após inoculação), $B_{1}=$ estimativa da assíntota máxima, $B_{2}=$ parâmetro relacionado ao inóculo inicial e $B_{3}=$ taxa de progresso da doença (Berger, 1981) e pelos modelos monomolecular e de Gompertz (Campbell \& Madden, 1990). A escolha do melhor modelo foi feita pelos valores do coeficiente de determinação $\left(R^{2}\right)$ e exame da distribuição do resíduo padrão (Bergamin Filho \& Amorim, 1996). Com os valores da estimativa da assíntota máxima para cada temperatura, em cada ensaio (parâmetro $B_{1}$ do modelo logístico), foi estimada a função beta generalizada, $Y=B_{1}\left(\left(X-B_{2}\right)^{\wedge} B_{4}\right)\left(\left(B_{3}-X\right)^{\wedge} B_{5}\right)$, 
descrita por Hau \& Kranz (1990), onde $Y$ representa a densidade relativa de lesões ou severidade estimada pela assíntota do modelo logístico, $X$ representa a temperatura e os parâmetros $B_{2}$ e $B_{3}$ representam, respectivamente, as temperaturas mínima e máxima. Os parâmetros $B_{1}, B_{4}$ e $B_{5}$ não possuem significado biológico.

O efeito da duração do período de molhamento foliar foi avaliado em dois ensaios, sob temperatura constante de $25{ }^{\circ} \mathrm{C}$ e fotoperíodo de $12 \mathrm{~h}$. Os períodos de molhamento, que corresponderam ao tempo em que as plantas inoculadas permaneceram envoltas com sacos plásticos umedecidos, foram de 2 h, 4 h, 8 h, 12 h, 16 h e 24 h. O delineamento experimental utilizado foi o inteiramente casualizado, com cinco repetições. Cada repetição foi composta por um vaso contendo uma planta, onde as duas folhas inoculadas foram avaliadas. Os componentes monocíclicos avaliados foram a densidade relativa de lesões e a severidade, seguindo a mesma metodologia empregada na avaliação dos ensaios de temperatura. Os dados também foram ajustados individualmente pelo modelo logístico. Com os valores da estimativa da assíntota máxima para cada período de molhamento, em cada ensaio (parâmetro $B_{1}$ do modelo logístico), foi estimada a função logística, $Y=B_{1} /\left(1+B_{2} \exp \left(-B_{3} X\right)\right)$, onde $Y=$ densidade relativa de lesões ou severidade estimada pela assíntota do modelo anterior, $X=$ molhamento, $B_{1}=$ estimativa da assíntota máxima, $B_{2}=$ parâmetro relacionado ao inóculo inicial e $B_{3}=$ taxa de progresso da doença.

As funções beta generalizada e logística, obtidas dos ensaios de avaliação da temperatura e da duração do período de molhamento foliar, respectivamente, foram multiplicadas para a elaboração de um modelo que indicasse o efeito das diferentes combinações de temperatura e de molhamento foliar no desenvolvimento da mancha de Alternaria em girassol, gerando uma superfície de resposta de densidade relativa de lesões ou de severidade em função dessas variáveis climáticas.

Para avaliar o efeito da temperatura no crescimento de colônias de $A$. helianthi, o fungo foi repicado para meio de farinha de aveia e cultivado por 7 dias a 25 ${ }^{\circ} \mathrm{C}$, sob iluminação contínua. Discos de micélio de $0,5 \mathrm{~cm}$ de diâmetro foram transferidos para meio de farinha de aveia em placas, incubadas no escuro, nas temperaturas constantes de $5^{\circ} \mathrm{C}, 15^{\circ} \mathrm{C}, 20{ }^{\circ} \mathrm{C}, 25^{\circ} \mathrm{C}, 27,5^{\circ} \mathrm{C}, 30^{\circ} \mathrm{C}$ e $32,5^{\circ} \mathrm{C}$. Foram 
realizados dois ensaios para cada temperatura, com delineamento experimental inteiramente casualizado e cinco repetições, sendo cada repetição composta por uma placa de Petri. As avaliações foram constituídas por medidas diárias do diâmetro das colônias, durante 16 dias. Foram estabelecidas curvas de crescimento micelial ao longo do tempo, para cada temperatura, em cada ensaio, através do modelo de regressão linear, $Y=A+B X$, onde $Y$ é o crescimento micelial, $X$ é o tempo (em dias de incubação), $A$ é o intercepto da reta e $B$ é a taxa de crescimento micelial. Com os valores da taxa de crescimento micelial (parâmetro $B$ da regressão linear), foi estabelecida uma curva de crescimento micelial em função da temperatura, ajustada pela função beta generalizada, $Y=B_{1}\left(\left(X-B_{2}\right)^{\wedge} B_{4}\right)\left(\left(B_{3}-X\right)^{\wedge} B_{5}\right)$, onde $Y$ representa a taxa de crescimento micelial, $X$ representa a temperatura e os parâmetros $B_{2}$ e $B_{3}$ representam, respectivamente, as temperaturas mínima e máxima.

Para avaliar o efeito da temperatura na germinação de conídios, o fungo foi repicado em meio de farinha de aveia e cultivado por 7 dias a $25{ }^{\circ} \mathrm{C}$, no escuro. Os conídios produzidos foram suspensos em água destilada esterilizada e a suspensão foi transferida para meio ágar-água em lâminas, colocadas em placas de Petri contendo um chumaço de algodão embebido em água, para manter a umidade. Essas foram incubadas no escuro, nas temperaturas de $10{ }^{\circ} \mathrm{C}, 15^{\circ} \mathrm{C}, 20^{\circ} \mathrm{C}, 25^{\circ} \mathrm{C}, 30^{\circ} \mathrm{C}, 35^{\circ} \mathrm{C}$ e $40{ }^{\circ} \mathrm{C}$. Após 24 h, os conídios foram corados com solução de lactofenol e a germinação foi avaliada, contando-se 200 conídios por lâmina. Foram realizados dois ensaios, em delineamento inteiramente casualizado, com três repetições, cada uma representada por uma lâmina. Com os valores da porcentagem média de germinação para cada temperatura, nos dois ensaios, foi estabelecida uma curva de germinação de conídios em função da temperatura, ajustada pela função beta generalizada, $Y=B_{1}\left(\left(X-B_{2}\right)^{\wedge} B_{4}\right)\left(\left(B_{3}-X\right)^{\wedge} B_{5}\right)$, onde $Y=$ porcentagem de germinação de conídios, $X=$ a temperatura e os parâmetros $B_{2}$ e $B_{3}$ são, respectivamente, as temperaturas mínima e máxima.

Dez híbridos de girassol foram avaliados quanto à resistência à infecção e à colonização por $A$. helianthi, em dois ensaios, sob temperatura constante de $25^{\circ} \mathrm{C}$ e molhamento foliar de $24 \mathrm{~h}$. A metodologia foi semelhante aos ensaios de temperatura e de molhamento foliar. $\mathrm{O}$ delineamento experimental foi inteiramente casualizado, com 
cinco repetições. Cada repetição foi composta por um vaso contendo uma planta, onde as duas folhas inoculadas foram avaliadas. Os componentes monocíclicos avaliados foram a densidade relativa de esões e a severidade, seguindo a mesma metodologia empregada na avaliação dos ensaios de temperatura e de molhamento foliar. Com os dados diários coletados, foram calculadas, por integração trapezoidal (Berger, 1988), para cada híbrido, as áreas sob a curva de progresso da densidade relativa de lesões durante 8 dias, para os dois ensaios e as áreas sob a curva de progresso da severidade durante 18 e 15 dias, respectivamente, para o primeiro e segundo ensaios. Para a análise da variância, foi utilizado o esquema fatorial, considerando ensaios e híbridos como fatores em estudo, com quatro repetições. As médias das áreas sob a curva de progresso da doença obtidas para os híbridos nos dois ensaios foram comparadas pelo teste de Tukey, ao nível de $1 \%$ de probabilidade.

\subsection{Resultados}

A temperatura influenciou a densidade relativa de lesões e a severidade da mancha de Alternaria em girassol (Apêndices 3 a 6) e este efeito foi representado pela função beta generalizada (Figura 1 e Tabela 1). A densidade relativa de lesões foi maior na temperatura de $25^{\circ} \mathrm{C}$ (Figura 1a). O aumento da temperatura provocou incremento na severidade da doença até aproximadamente $30^{\circ} \mathrm{C}$, a partir da qual decresceu de forma acentuada (Figura 1b). A temperatura mínima para desenvolvimento da doença, estimada pela função beta generalizada, foi de $13,0{ }^{\circ} \mathrm{C}$ e $14,9{ }^{\circ} \mathrm{C}$ e a máxima foi de 35,8 ${ }^{\circ} \mathrm{C}$ e $35,6{ }^{\circ} \mathrm{C}$, respectivamente, para densidade relativa de lesões e severidade (Tabela 1).

A mancha de Alternaria foi maior com o aumento da duração do período de molhamento foliar (Apêndices 7 a 10), o que foi descrito pelo modelo logístico (Figura 2 e Tabela 2). Tanto para densidade relativa de lesões como para a severidade da doença, o ponto de inflexão da curva logística se deu em torno de $12 \mathrm{~h}$ de molhamento foliar (Figura 2). Não foi observada infecção na ausência de molhamento. A severidade e densidade relativa de lesões mais elevadas foram observadas com o molhamento foliar de pelo menos $16 \mathrm{~h}$. 

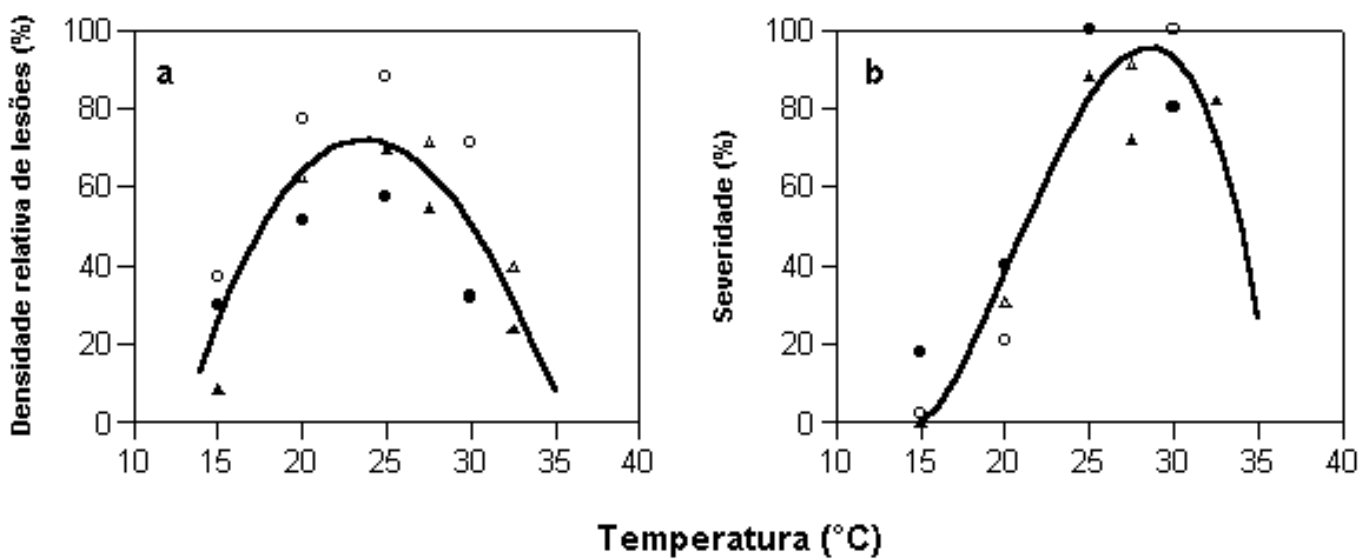

Figura 1 - Densidade relativa de lesões (a) e severidade (b) de A. helianthi em girassol, em função da temperatura, nos ensaios 1 (círculo cheio), 2 (círculo vazio), 3 (triângulo cheio) e 4 (triângulo vazio). Linhas correspondem à função beta generalizada ajustada aos dados.

Tabela 1. Coeficientes de determinação $\left(R^{2}\right)$ e parâmetros da função beta generalizada, $Y=B_{1}\left(\left(X-B_{2}\right)^{\wedge} B_{4}\right)\left(\left(B_{3}-X\right)^{\wedge} B_{5}\right)$, onde $Y$ é o componente monocíclico considerado, $X$ é a temperatura, os parâmetros $B_{2}$ e $B_{3}$ são, respectivamente, as temperaturas mínima e máxima e $B_{1}, B_{4}$ e $B_{5}$ são parâmetros da equação sem significado biológico, ajustada para as diferentes temperaturas.

\begin{tabular}{lcccccc}
\hline Componentes monocíclicos & $\boldsymbol{B}_{\mathbf{1}}$ & $\boldsymbol{B}_{\mathbf{2}}$ & $\boldsymbol{B}_{\mathbf{3}}$ & $\boldsymbol{B}_{\mathbf{4}}$ & $\boldsymbol{B}_{\mathbf{5}}$ & $\boldsymbol{R}^{\mathbf{2}}$ \\
\hline Densidade relativa de lesões & 0,50699 & 13,09 & 35,82 & 0,95 & 1,08 & 0,82 \\
Severidade & 0,32814 & 14,99 & 35,67 & 1,57 & 0,80 & 0,94 \\
Taxa de crescimento micelial & 0,00007 & 5,50 & 32,97 & 2,37 & 0,44 & 0,91 \\
Germinação de conídios & 3,91605 & 7,99 & 40,00 & 0,80 & 0,27 & 0,98 \\
\hline
\end{tabular}



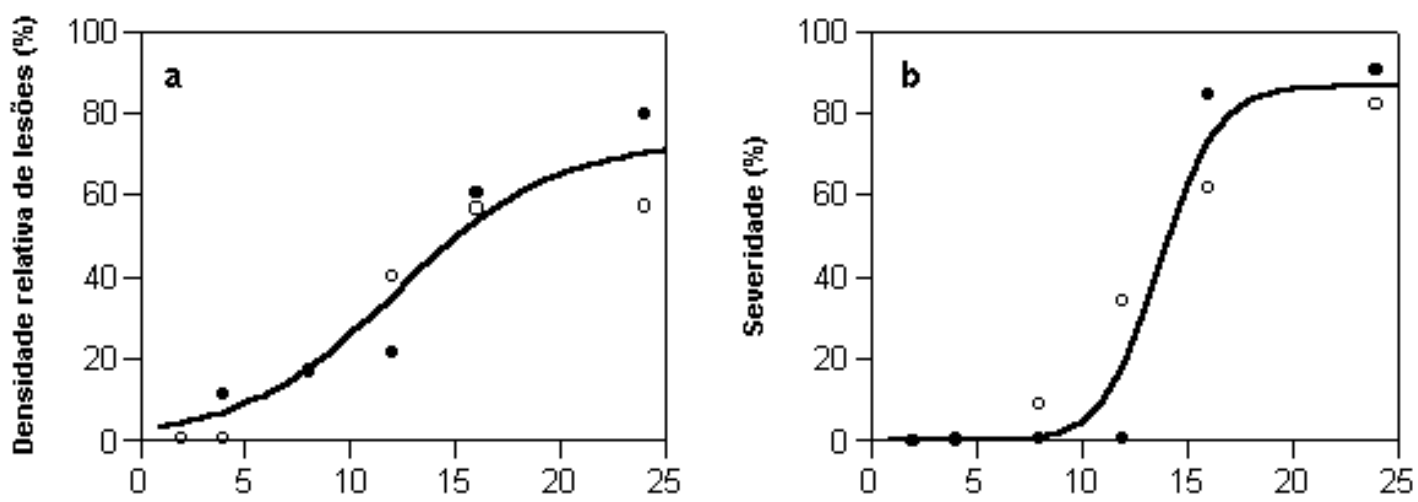

Duração do molhamento foliar (h)

Figura 2 - Densidade relativa de lesões (a) e severidade (b) de A. helianthi em girassol, em função da duração do período de molhamento foliar, nos ensaios 1 (círculo cheio) e 2 (círculo vazio). Linhas correspondem à função logística ajustada aos dados.

Tabela 2. Coeficientes de determinação $\left(R^{2}\right)$ e parâmetros da função logística, $Y=B_{1} /\left(1+B_{2} \exp \left(-B_{3} X\right)\right)$, onde $Y$ é o componente monocíclico considerado, $X$ é a duração do período de molhamento, $B_{1}$ é estimativa da assíntota máxima, $B_{2}$ é o parâmetro relacionado ao inóculo inicial e $B_{3}$ é a taxa de progresso da doença, ajustada para as diferentes durações de período de molhamento foliar.

\begin{tabular}{llrrc}
\hline Componentes monocíclicos & $\boldsymbol{B}_{\mathbf{1}}$ & \multicolumn{1}{c}{$\boldsymbol{B}_{\mathbf{2}}$} & $\boldsymbol{B}_{\mathbf{3}}$ & $\boldsymbol{R}^{\mathbf{2}}$ \\
\hline Densidade relativa de lesões & 73,09 & 27,63 & 0,27 & 0,93 \\
Severidade & 86,59 & 30833,95 & 0,74 & 0,97 \\
\hline
\end{tabular}

A superfície de resposta obtida pela multiplicação das funções beta generalizada, gerada para os ensaios de temperatura, e logística, ajustada para os ensaios de duração do período de molhamento foliar (Figura 3), mostrou um bom ajuste para os dados observados, tanto para densidade relativa de lesões $\left(R^{2}=0,87\right)$, quanto para severidade $\left(R^{2}=0,92\right)$. 

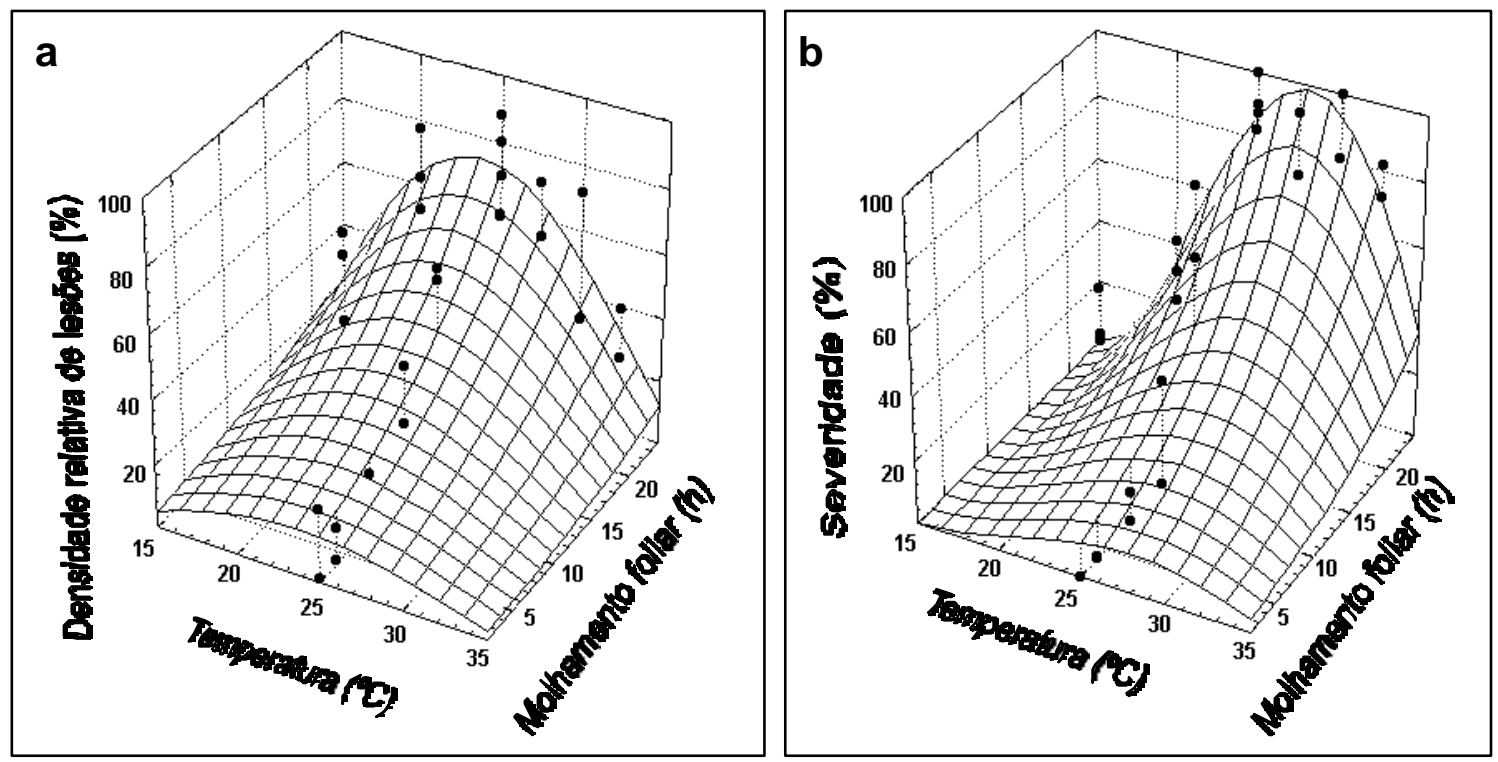

Figura 3 - Superfície de resposta da densidade relativa de lesões (a) e da severidade (b) de A. helianthi em girassol, em função da temperatura e da duração do período de molhamento foliar, descrita pela função $Y=\left(B_{1}\left(\left(T-B_{2}\right)^{\wedge} B_{3}\right)\left(\left(B_{4}\right.\right.\right.$ $\left.\left.T)^{\wedge} B_{5}\right)\right)\left(\left(B_{6} /\left(1+B_{7} \exp \left(-B_{8} M\right)\right)\right)\right.$, onde $Y$ é o componente monocíclico considerado, $T$ é a temperatura, $M$ é a duração do período de molhamento foliar e $B_{1}$ a $B_{8}$ são parâmetros do modelo.

A superfície de resposta para estimar a densidade relativa de lesões pôde ser descrita pela função:

$$
D=\left(0,07\left((T-12,13)^{\wedge} 1,30\right)\left((37,30-T)^{\wedge} 1,51\right)\right)(10,48 /(1+(81,81 \exp (-(-0,073) M))))
$$

onde $D$ é a densidade relativa de lesões em porcentagem, $T$ é a temperatura em ${ }^{\circ} \mathrm{C}$ e $M$ é a duração do período de molhamento foliar em horas.

O modelo elaborado para estimar a severidade de A. helianthi em girassol pôde ser descrito pela função:

$$
S=\left(1,07\left((T-14,99)^{\wedge} 1,95\right)\left((37,34-T)^{\wedge} 1,38\right)\right)(86,93 /(1+(30833,94 \exp (-(-0,094) M))))
$$

onde $S$ é a severidade em porcentagem, $T$ é a temperatura em ${ }^{\circ} \mathrm{C}$ e $M$ é a duração do período de molhamento foliar em horas. 
Por meio dessas funções, a temperatura mínima para desenvolvimento da doença foi de $12,1^{\circ} \mathrm{C}$ e $14,9{ }^{\circ} \mathrm{C}$ e a máxima foi de $37,3{ }^{\circ} \mathrm{C}$ e $37,3{ }^{\circ} \mathrm{C}$, respectivamente, para densidade relativa de lesões e severidade da mancha de Alternaria. Ambos componentes monocíclicos avaliados crescem com o aumento da duração do período de molhamento foliar, apresentando o máximo com $24 \mathrm{~h}$ de molhamento e $25{ }^{\circ} \mathrm{C}$ de temperatura.

O crescimento micelial e a germinação de conídios em função da temperatura (Apêndices 11 e 12) também foram descritos pela função beta generalizada (Figura 4 e Tabela 1). Não foi observado crescimento micelial a $5{ }^{\circ} \mathrm{C}$. A taxa de crescimento micelial foi maior na temperatura de $27,5{ }^{\circ} \mathrm{C}$ (Figura $4 \mathrm{a}$ ) A temperatura mínima estimada para a taxa de crescimento micelial foi de $5,5{ }^{\circ} \mathrm{C}$ e a máxima foi de $32,9{ }^{\circ} \mathrm{C}$, estimadas pela função beta generalizada (Tabela 1). $\mathrm{O}$ aumento da temperatura provocou um incremento na germinação de conídios até aproximadamente $35{ }^{\circ} \mathrm{C}$, a partir da qual decresceu de forma acentuada, chegando a próximo de zero na temperatura de $40{ }^{\circ} \mathrm{C}$ (Figura 4b). De fato, de acordo com os parâmetros estimados pela função beta generalizada, a temperatura mínima para germinação de conídios foi de $7,9{ }^{\circ} \mathrm{C}$ e a máxima foi de $40,0{ }^{\circ} \mathrm{C}$ (Tabela 1$)$.

Houve diferença estatística significativa entre os 10 híbridos inoculados artificialmente, tanto para a área sob a curva de progresso da densidade relativa de lesões quanto para a área sob a curva de progresso da severidade de A. helianthi (Apêndices 13 e 14), na análise conjunta dos dados obtidos nos dois ensaios (Tabela 3). M742 e HT14 mostraram menor densidade relativa de lesões, não diferindo significativamente de M734, HT9 e HT1. Os híbridos Agrobel 910 e SE02 foram os mais suscetíveis quanto a densidade relativa de lesões e BRS 191 quanto a severidade. Não houve diferença estatística significativa ao nível de $1 \%$ de probabilidade para a média dos dois ensaios, bem como para a interação híbridos x ensaios. 

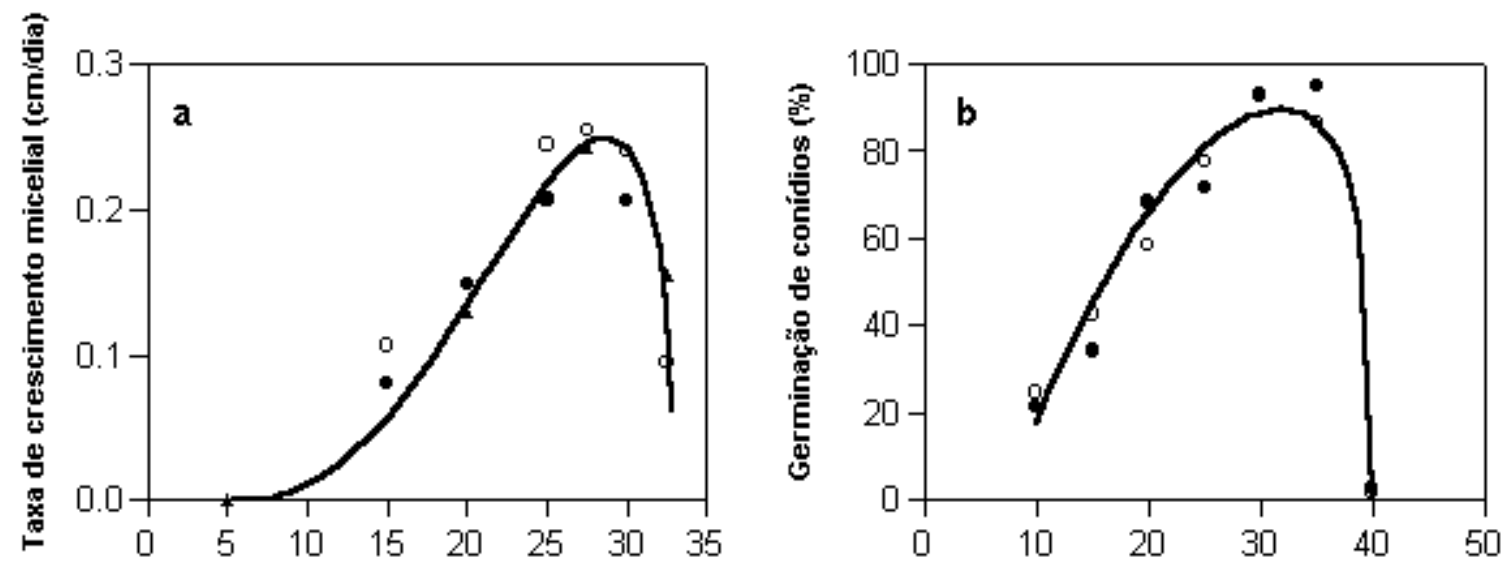

Temperatura $\left({ }^{\circ} \mathrm{C}\right)$

Figura 4 - Taxa de crescimento micelial (a) e germinação de conídios (b) de A. helianthi in vitro, em função da temperatura, nos ensaios 1 (círculo cheio), 2 (círculo vazio) e 3 (triângulo cheio). Linhas correspondem à função beta generalizada ajustada aos dados.

Tabela 3. Reação de híbridos de girassol inoculados artificialmente, em condições controladas, à infecção e colonização por A. helianthi.

\begin{tabular}{|c|c|c|c|}
\hline \multirow{2}{*}{ Híbrido } & \multirow[t]{2}{*}{ Empresa } & \multicolumn{2}{|c|}{ Área sob a curva de progresso de: } \\
\hline & & $\begin{array}{c}\text { Densidade relativa } \\
\text { de lesões* }\end{array}$ & Severidade* \\
\hline M734 & Morgan-Mycogen & $295,03 \mathrm{abc}$ & $307,28 \mathrm{a}$ \\
\hline M742 & Morgan-Mycogen & $212,37 \mathrm{a}$ & $396,97 \mathrm{ab}$ \\
\hline HT14 & Embrapa Soja & $235,22 \mathrm{a}$ & $551,84 \mathrm{ab}$ \\
\hline Agrobel 920 & Agromania & $381,23 \mathrm{~cd}$ & $579,70 \mathrm{ab}$ \\
\hline Agrobel 960 & Agromania & $387,28 \mathrm{~cd}$ & $664,10 a b$ \\
\hline HT9 & Embrapa Soja & $272,95 \mathrm{abc}$ & $666,35 \mathrm{ab}$ \\
\hline Agrobel 910 & Agromania & $424,25 \mathrm{~d}$ & $676,96 \mathrm{ab}$ \\
\hline HT1 & Embrapa Soja & $249,72 \mathrm{ab}$ & $731,39 \mathrm{ab}$ \\
\hline SE02 & Embrapa Soja & $439,93 \mathrm{~d}$ & $748,21 \mathrm{ab}$ \\
\hline BRS 191 & Embrapa Soja & $354,22 \mathrm{bcd}$ & $779,43 \mathrm{~b}$ \\
\hline
\end{tabular}

* médias seguidas de mesma letra na coluna não diferem entre si pelo teste de Tukey, ao nível de $1 \%$ de probabilidade. 


\subsection{Discussão}

Nos ensaios de avaliação do efeito da temperatura e da duração do período de molhamento foliar em câmara de crescimento, os dados da densidade relativa de lesões durante 8 dias e da severidade da doença durante 21 dias foram melhor ajustados individualmente pelo modelo logístico. Os modelos monomolecular e Gompertz não ofereceram ajustes adequados. Esta observação é concordante com o observado por Sentelhas et al. (1996), que comparou curvas de progresso da doença em três cultivares de girassol. Godoy \& Fernandes (1985b), comparando o ajuste de curvas de progresso da doença em cultivares de girassol semeados em campo, verificaram que o modelo de Gompertz foi melhor que o logístico, com valores de coeficiente de determinação mais elevados.

O modelo beta generalizado apresenta forma de sino e é um modelo não linear com cinco parâmetros. Dois deles têm significado biológico, porque estimam as temperaturas mínima (parâmetro $B_{2}$ ) e máxima (parâmetro $B_{3}$ ) do processo biológico em estudo (Hau \& Kranz, 1990). Este modelo tem sido útil em descrever a influência da temperatura em diversos patossistemas (Bassanezi et al., 1998; Carneiro \& Amorim, 1999; Godoy et al., 1999). O parâmetro $B_{5}$ está relacionado à forma da curva e pode ser utilizado para determinar a amplitude do intervalo de temperatura ótima em cada componente epidemiológico analisado (Bassanezi et al., 1998). Valores próximos a zero indicam que existe uma ampla faixa de temperatura na qual o componente em estudo permanece próximo ao valor máximo, enquanto que valores altos mostram que a faixa de temperatura ótima é mais estreita. Neste trabalho, os valores determinados de 1,08 para densidade relativa de lesões e 0,80 para severidade (Tabela 1) indicam que a doença é severa numa ampla faixa de variação de temperatura, que pode oscilar em até $10{ }^{\circ} \mathrm{C}$ em torno da ótima (Figura 1). Este fato pode explicar porque a mancha de Alternaria é uma das doenças mais importantes para o girassol no Brasil, podendo ser encontrada em todas as regiões e em todas as épocas de semeadura (Leite, 1997), mesmo sujeita a uma ampla variação de temperatura que é encontrada nas diferentes regiões e épocas. 
A faixa ótima de temperatura para o desenvolvimento da doença observada no presente trabalho situa-se entre $25^{\circ} \mathrm{C}$ e $30^{\circ} \mathrm{C}$, o que está de acordo com Islam \& Maric (1980), que mostraram que temperaturas na faixa entre $24{ }^{\circ} \mathrm{C}$ a $27{ }^{\circ} \mathrm{C}$ favoreceram o desenvolvimento dessa doença, quando comparadas com $17^{\circ} \mathrm{C}$. Também, a epidemia de $A$. helianthi na Austrália está associada a temperaturas médias de $25{ }^{\circ} \mathrm{C}$ $30{ }^{\circ} \mathrm{C}$ (Allen et al., 1983b). Segundo Rotem (1994), a temperatura ótima para infecção é de $26{ }^{\circ} \mathrm{C}$. Na Índia, em condições de campo, a temperatura favorável para o desenvolvimento da doença variou entre $27{ }^{\circ} \mathrm{C}$ e $29{ }^{\circ} \mathrm{C}$ (Kumar \& Singh, 1996).

A não ocorrência de infecção observada na ausência de molhamento foliar confirma a necessidade de água livre na superfície foliar para o estabelecimento da doença no hospedeiro. Islam \& Maric (1980) mostraram que um período mínimo de $12 \mathrm{~h}$ de umidade do ar saturada é necessário para a infecção bem sucedida de A. helianthi em girassol. Allen et al. (1983b) também verificaram que um período de molhamento foliar de 12 h é requerido para proporcionar o máximo de infecção, o que confirma que, na Austrália, a epidemia da doença coincide com períodos longos de umidade.

Essa quantidade de horas de período de molhamento não necessita ser contínua, uma vez que espécies de Alternaria podem esporular ou causar infecção em plantas durante vários períodos curtos de molhamento, ao invés de um único período longo. Este regime de período de molhamento interrompido permite que a infecção ocorra durante períodos úmidos ànoite e seja interrompida por dias secos. Assim, a germinação de esporos inicia-se na primeira noite úmida, pára no dia seguinte seco e é concluída na próxima noite úmida, sendo esse processo repetido até que o tubo germinativo penetre o hospedeiro (Rotem, 1994). Esse fenômeno pode ocorrer na infecção de girassol por A. helianthi, baseado no trabalho de Allen et al. (1983b).

A temperatura influiu significativamente no crescimento de colônias de $A$. helianthi, o que também foi observado por Sujatha et al. (1997), e na germinação de conídios do fungo. Os dados de crescimento micelial observados no presente estudo são concordantes com os obtidos por Abbas et al. (1995), que verificaram que A. helianthi cresceu bem nas temperaturas entre $18{ }^{\circ} \mathrm{C}$ a $30{ }^{\circ} \mathrm{C}$, mas não a $15{ }^{\circ} \mathrm{C}$ ou a $33{ }^{\circ} \mathrm{C}$. Esses autores observaram que o fungo cresceu mais rápido a 28 e a $30^{\circ} \mathrm{C}$, o que está próximo 
do verificado no presente estudo $\left(27,5^{\circ} \mathrm{C}\right)$. Em meio de BDA, Reddy \& Gupta (1981) e Allen et al. (1983b) observaram que o crescimento de colônias foi maior a $25{ }^{\circ} \mathrm{C}$. Para a germinação de conídios, as temperaturas mínima $\left(7,9^{\circ} \mathrm{C}\right)$ e máxima $\left(40,0{ }^{\circ} \mathrm{C}\right)$, estimadas pela função beta generalizada, estão de acordo com o compilado por Rotem (1994), que indica que as temperaturas mínima, ótima e máxima para germinação in vitro são, respectivamente, de $<10{ }^{\circ} \mathrm{C}, 25-28{ }^{\circ} \mathrm{C}$ e $<40{ }^{\circ} \mathrm{C}$.

$\mathrm{Na}$ avaliação de híbridos de girassol, os componentes monocíclicos da resistência horizontal utilizados foram a densidade relativa de lesões e a severidade, como utilizado por Godoy \& Ferna ndes (1985b). A resistência à infecção foi dada pelo menor número de lesões formadas, enquanto que a resistência à colonização foi representada pela menor severidade. Observoutse diferenças quanto ao nível de resistência à infecção e à colonização por A. helianthi nos materiais avaliados.

Os resultados obtidos no presente trabalho permitem concluir que as condições ótimas para o estabelecimento da doença situam-se em $25^{\circ} \mathrm{C}$ e $24 \mathrm{~h}$ de molhamento foliar. Essas características devem ser consideradas no desenvolvimento de um modelo de previsão para a mancha de Alternaria. De fato, Das et al. (1998) confirmaram que a doença pode ser prevista usando variáveis climáticas. Esses autores verificaram que a temperatura do ar teve um efeito significativo na previsão da doença em girassol. Sentelhas et al. (1996) sugeriram que as variáveis chuva total e temperatura mínima do ar sejam utilizadas no desenvolvimento desses sistemas de previsão.

Para reduzir as perdas causadas por A. helianthi em girassol, é fundamental a escolha da época de semeadura, o que também vem sendo recomendado na Austrália (Allen et al., 1983b) e na Índia (Sahu et al., 1991). Sahu et al. (1991) recomenda que sejam evitadas as épocas de semeadura em que a planta esteja jovem durante períodos de alta umidade, já que este favorece a infecção. Conseqüentemente, sugere-se que o girassol seja semeado numa época que permita que a cultura se desenvolva e amadureça quando as condições ambientais, principalmente temperatura e molhamento foliar, sejam menos favoráveis para o desenvolvimento da doença (Allen et al., 1983a). Além disso, a importância da seleção de materiais com maior nível de resistência também deve ser ressaltada, uma vez que essas condições climáticas 
favoráveis ocorrem na área potencialmente produtora de girassol no Brasil, tornando a cultura vulnerável a epidemias.

\subsection{Conclusões}

A mancha de Alternaria é favorecida por temperaturas entre $25^{\circ} \mathrm{C}$ e 30 ${ }^{\circ} \mathrm{C}$ e 24 h de molhamento foliar.

A temperatura ótima para crescimento de colônias de A. helianthi é de $27,5^{\circ} \mathrm{C}$ e para germinação de conídios é de $35^{\circ} \mathrm{C}$. 


\section{RELAÇÕES DE VARIÁVEIS DE DOENÇA E DE ÁREA FOLIAR COM COMPONENTES DE PRODUÇÃO PARA O PATOSSISTEMA Alternaria helianthi - GIRASSOL}

\section{Resumo}

Três experimentos foram conduzidos nas safras de 1997/1998, 1998/1999 e 1999/2000 para avaliar a relação entre severidade da mancha de Alternaria $(X)$, causada por Alternaria helianthi, área sob a curva de progresso da doença (AUDPC), índice de área foliar sadia em determinado dia (HLAI), duração da área foliar sadia $(H A D)$, radiação interceptada pela área foliar sadia em determinado dia (HRI), absorção da área foliar sadia $(H A A)$ e componentes de produção de girassol, semeado em quatro épocas. A $A U D P C$ teve relação com rendimento de aquênios, com ajuste do modelo exponencial negativo em duas safras $\left(\mathrm{R}^{2}=0,79\right.$ e 0,60$)$. A relação rendimento x $H A D$ foi linear (interseção forçada a zero) para os três experimentos $\left(0,73<R^{2}<0,83\right)$. Para as variáveis integrais estudadas, a melhor relação com rendimento foi verificada para $H A A$, com ajuste do modelo exponencial $\left(0,77<R^{2}<0,89\right)$. Modelos de ponto crítico usando severidade, HLAI e HRI para estimar a produção em diferentes fases de desenvolvimento da cultura foram testados. A taxa da relação severidade $\mathrm{x}$ rendimento tendeu a se estabilizar a partir da fase R1 (aparecimento do botão floral). A taxa da relação linear entre HLAI e rendimento estabilizoutse entre as fases R1 a R6 (floração final) e tornou a subir a partir da fase R7 (primeira fase de desenvolvimento de aquênios). Diferentemente das taxas de severidade ou HLAI x rendimento, a taxa da regressão entre HRI e rendimento foi bastante variável e não mostrou tendência de estabilização. Analisando a relação entre rendimento de aquênios e valores de severidade na fase de 
desenvolvimento R3 (segunda fase de alongamento do broto floral), verificou-se que plantas que apresentaram severidade maior que $10 \%$ nessa fase produziram rendimentos inferiores a $500 \mathrm{~kg} / \mathrm{ha}$, para as três safras, independentemente da época de semeadura. Esse valor pode ser utilizado como um limiar de dano para a doença. A severidade pode ser usada como uma variável independente para um sistema de manejo da mancha de Alternaria em girassol e pode ser usada para produzir recomendações em trabalhos de pesquisa, como melhoramento genético visando resistência à doença ou escolha de época de semeadura.

\section{Summary}

\section{Relationships of disease and leaf area variables with yield for Alternaria helianthi - sunflower pathosystem}

Three field experiments were carried out in 1997/1998, 1998/1999 and $1999 / 2000$ to investigate the relationship between severity $(X)$ of Alternaria leaf spot, caused by Alternaria helianthi, area under disease progress curve (AUDPC), healthy leaf area index at any given day (HLAI), healthy leaf area duration (HAD), radiation intercepted by healthy leaf area at any given day $(H R I)$, total healthy leaf area absorption $(H A A)$, and yield components of sunflower, sowed in four dates. AUDPC showed relationship with yield in two years, following the negative exponential model $\left(\mathrm{R}^{2}=\right.$ 0.79 and 0.60 ). The yield $\mathrm{x} H A D$ relationship was linear for each of three trials $\left(73<R^{2}<83 \%\right)$. Among the integral variables analysed, the yield $\mathrm{x} H A A$ relationship was the best one, fitted by the exponential model $\left(77<R^{2}<89 \%\right)$. Single-point models using severity, $H L A I$ and $H R I$ to estimate yield at various times during the crop season were tested. The slope of the yield-severity relationship was stable from R1 growth stage. The yield-HLAI relationship was stable between R1 and R6 and increased from R7 stage. The yield-HRI relationship was variable and not stable. The yield-severity relationship in R3 growth stage proved that plants with severity higher than $10 \%$ had yield lower than $500 \mathrm{~kg} / \mathrm{ha}$, despite the sowing date. This value can be used as a damage threshold 
for the disease. Severity can be used as an independent variable to a system of sunflower Alternaria leaf spot management and can be used to produce recommendations at the research level, like genetic breeding for disease resistance or studies on planting date.

\subsection{Introdução}

O girassol (Helianthus annuus L.) é hospedeiro de mais de 36 microrganismos patogênicos, na maioria fungos, que podem, dependendo de condições climáticas favoráveis, levar à redução significativa da produção e da qualidade do produto (Gulya et al., 1997). Estima-se que as doenças causam uma perda anual de $12 \%$ da produção de girassol no mundo (Zimmer \& Hoes, 1978). Cerca de 16 doenças já foram relatadas no Brasil, algumas com importância significativa (Yorinori et al., 1985). No Brasil, não há dados exatos sobre qual a perda na produção provocada pelas doenças, mas sabe-se que esta pode ser mínima ou chegar a 100\%, dependendo das condições climáticas (Yorinori et al., 1985). A mancha de Alternaria, causada por Alternaria helianthi (Hansf.) Tubaki \& Nishihara, tem sido a doença predominante, ocorrendo em praticamente todas as regiões e em todas as épocas de semeadura (Leite, 1997).

O desenvolvimento e a implementação de uma estratégia de manejo de doenças na cultura do girassol requer informações precisas e acuradas sobre o dano causado pelos patógenos. O dano é definido como qualquer redução na qualidade ou quantidade da produção que é resultante de uma injúria. A injúria é qualquer sintoma visível causado por patógenos ou pragas (Bergamin Filho, 1995). Assim, a quantificação da doença, normalmente expressa em severidade, para doenças foliares, é importante para se estabelecer o nível de dano que esta está causando nos componentes de produção do girassol.

Historicamente, diversos modelos têm sido utilizados para descrever a relação entre a severidade da doença e a produção, considerando um único ou vários estádios de desenvolvimento da planta. Modelos de ponto crítico geralmente relacionam os componentes de produção com a severidade $(X)$ em determinada fase de desenvolvimento do hospedeiro, que está altamente correlacionada com o dano futuro. 
Modelos integrais relacionam a produção com uma variável que represente a totalidade da epidemia, como a área sob a curva de progresso da doença (AUDPC). Entretanto, esses modelos nem sempre são transportáveis para a previsão de danos em outras localidades e safras agrícolas (Bergamin Filho \& Amorim, 1996).

A produção é função da área foliar da planta ou de seu índice de área foliar ( $L A I)$ em determinada fase ou da duração da área foliar ( $L A D)$, que é a integração do LAI ao longo da estação de crescimento (Watson, 1947). Monteith (1977) relacionou produção com a radiação interceptada $(R I)$ pela copa da planta em determinada fase ou ainda com a integração de $R I$ ao longo da estação de crescimento, que é a absorção da área foliar $(L A A)$.

Waggoner \& Berger (1987) afirmam que produção de uma planta é função, em grande parte, da fotossíntese que ocorre nas folhas. No contexto fitopatológico, esses autores salientaram a importância de se considerar a área foliar que permanece sadia durante o ciclo, ou seja, que não foi afetada pela doença, adaptando os conceitos de Watson (1947) e de Monteith (1977) à avaliação de danos causados por doenças. Assim, definiram índice de área foliar sadia (HLAI), duração da área foliar sadia $(H A D)$, radiação interceptada pela copa sadia da planta $(H R I)$ e absorção da área foliar sadia $(H A A)$.

O objetivo deste trabalho foi comparar a relação de componentes integrais $(A U D P C, H A D, H A A)$ ou pontuais $(X, H L A I, H R I)$ relacionados à mancha de Alternaria ou à área foliar com os componentes de produção de girassol, para melhor basear as estratégias de manejo da doença.

\subsection{Material e Métodos}

\subsubsection{Experimentos de campo}

Os experimentos de campo foram conduzidos na área experimental da Embrapa - Centro Nacional de Pesquisa de Soja (Embrapa Soja), em Londrina, PR, em três safras consecutivas: 1997/1998, 1998/1999 e 1999/2000. Foi utilizado o híbrido simples de girassol SE02, de ciclo precoce, desenvolvido pelo programa de 
melhoramento genético de girassol da Embrapa Soja. Todos os experimentos seguiram o mesmo delineamento experimental, que foi em blocos ao acaso, com quatro épocas de semeadura (outubro, novembro, dezembro e janeiro), dois tratamentos (semeaduras contígua e isolada) e quatro repetições. Cada parcela foi constituída por 4 linhas de $5 \mathrm{~m}$, espaçadas de $0,90 \mathrm{~m}$, onde foram deixadas 3 plantas por metro linear. A implantação e condução do girassol seguiram as recomendações feitas para a cultura, incluindo adubação na semeadura e de cobertura, capinas, pulverização contra insetos e irrigação, quando necessárias (Castro et al., 1996). Os experimentos foram implantados em área intensivamente utilizada para experimentação de girassol. Para estabelecer parcelas com diferentes níveis de severidade da doença, a semeadura foi escalonada nos meses de outubro, novembro, dezembro e janeiro de cada safra, em dois tratamentos: semeaduras contígua e isolada. O primeiro tratamento teve todas as parcelas das diferentes épocas de semeadura localizadas lado ao lado, enquanto que, no outro tratamento, as parcelas das diferentes épocas de semeadura foram separadas por seis fileiras de milho, que funcionou como uma barreira vegetal não hospedeira do patógeno, de modo a isolar o girassol. Não houve inoculação artificial de A. helianthi, já que a doença ocorreu por infecção natural das plantas pelo fungo. O patógeno foi identificado por meio de isolamento em laboratório e inoculação em plantas em casa de vegetação.

\subsubsection{Avaliações de desenvolvimento das plantas, severidade da doença e produção}

As avaliações de desenvolvimento das plantas, severidade da doença e produção foram feitas nas duas linhas centrais de cada parcela, descartando 0,5 $\mathrm{m}$ de cada extremidade da linha. O sistema de plantas individuais foi adotado (Kranz \& Jörg, 1989), onde 10 ou 8 plantas homogêneas de cada parcela foram marcadas, totalizando 320 plantas para a primeira safra e 256 para as duas seguintes. As plantas foram escolhidas, a partir da emissão da quarta folha verdadeira (fase V4) (Schneiter \& Miller, 1981), com o cuidado de selecionar indivíduos de mesmo desenvolvimento, altura e vigor.

Em cada planta marcada, a área foliar $(L A)\left(\mathrm{cm}^{2}\right)$ de todas as folhas foi estimada semanalmente, a partir da emissão da quarta folha verdadeira (fase V4). Para 
tanto, a maior largura $(L)(\mathrm{cm})$ de cada folha foi medida com uma régua. A área foliar foi calculada pela equação $L A=-155,86+22,40 L\left(\mathrm{R}^{2}=90,0 \%\right)$ (Leite \& Amorim, 2002). Simultaneamente, a mancha de Alternaria foi estimada em todas as folhas, com o auxílio de uma escala diagramática da doença, previamente elaborada e validada (Leite \& Amorim, 2002). Plantas marcadas afetadas por outras doenças ou que apresentaram qualquer problema prejudicial ao seu desenvolvimento, durante as avaliações, foram desconsideradas. Em cada avaliação, a fase de desenvolvimento da planta foi anotada, de acordo com a escala de Schneiter \& Miller (1981), traduzida por Castiglioni et al. (1994): $\mathrm{V}-\mathrm{E}=$ emergência; $\mathrm{Vn}=\mathrm{n}$ folhas com comprimento maior que $4 \mathrm{~cm}$; $\mathrm{R} 1=$ aparecimento do broto floral; R2 = primeira fase de alongamento do broto floral; R3 = segunda fase de alongamento do broto floral; R4 = primeira fase do florescimento; R5 = segunda fase do florescimento; $\mathrm{R} 6=$ floração final; $\mathrm{R} 7=$ primeira fase de desenvolvimento de aquênios; R8 = segunda fase de desenvolvimento de aquênios; R9 = maturação fisiológica.

As plantas marcadas foram colhidas individualmente, após a fase de maturação fisiológica (R9) (Schneiter \& Miller, 1981). Foram avaliados o rendimento de aquênios ( $\mathrm{kg} / \mathrm{ha})$, número de aquênios por planta, altura de planta $(\mathrm{cm})$, diâmetro de caule $(\mathrm{mm})$, diâmetro de capítulo $(\mathrm{cm})$ e teor de óleo $(\%)$, de acordo com Castiglioni et al. (1994). O teor de óleo foi analisado por meio de ressonância magnética nuclear (NMR) (Granlund \& Zimmerman, 1975), com o equipamento NMR, marca Oxford, modelo 4000 .

\subsubsection{AUDPC, LAI, HLAI, HAD, RI, HRI e HAA}

As variáveis utilizadas para correlação com os componentes de produção foram: severidade da mancha de Alternaria $(X)$, área sob a curva de progresso da doença $(A U D P C)$, índice de área foliar sadia em determinado dia $(H L A I)$, duração da área foliar sadia $(H A D)$, radiação interceptada pela área foliar sadia em determinado dia $(H R I)$ e absorção da área foliar sadia $(H A A)$. As equações para cálculo das diferentes variáveis estão publicadas em Bergamin Filho et al. (1997). 
O valor de $A U D P C$ para cada planta foi calculado pela fórmula:

$$
A U D P C=\sum_{i=1}^{n-1}\left(\left(X_{i}+X_{i+1}\right) / 2\right)\left(t_{i_{+1}}-t_{i}\right)
$$

onde $X_{i}=X\left(t_{i}\right), n$ foi o número de avaliações, $X$ foi a severidade da doença (em \%) e $\left(t_{i+1}-t_{i}\right)$ foi o intervalo entre duas avaliações consecutivas.

Os valores de LAI foram obtidos dividindo a área foliar total de cada planta em cada avaliação pela área ocupada do terreno por cada planta. Esta foi calculada multiplicando a metade da distância entre a planta marcada e suas vizinhas na linha, pelo espaçamento entre linhas $(0,90 \mathrm{~m})$.

O índice de área foliar sadia (HLAI), para cada avaliação, foi calculado pela fórmula:

\section{$H L A I=L A I(1-X)$}

O valor de $H A D$ (dias) para cada planta foi calculado pela fórmula:

$$
H A D=\sum_{i=1}^{n-1}\left(\left(L A I_{i}\left(1-X_{i}\right)+L A I_{i+1}\left(1-X_{i+1}\right)\right) / 2\right)\left(t_{i+1}-t_{i}\right)
$$

onde $L A I_{i}=L A I\left(t_{i}\right)$.

$\mathrm{O}$ valor de $R I_{i}\left(\mathrm{MJ} \mathrm{m}^{-2}\right)$ foi obtido pela fórmula:

$$
R I_{i}=I_{i}\left(1-\exp \left(-k L A I_{i}\right)\right)
$$

onde $I_{i}$ é a radiação solar incidente média $\left(\mathrm{MJ} \mathrm{m}^{-2}\right)$ no período $\left(t_{i+1}-t_{i}\right)$ e $k$ é o coeficiente de extinção. Para a cultura do girassol, o valor de $k$ utilizado foi de 0,97 (Monteith, 1969). Os dados de radiação solar incidente foram coletados na estação meteorológica da Embrapa Soja, distante 1700 m dos experimentos. Foram utilizados os valores médios para os intervalos entre as avaliações.

A radiação interceptada pela área foliar sadia $(H R I)\left(\mathrm{MJ} \mathrm{m}^{-2}\right)$, para cada avaliação, foi calculada pela fórmula:

\section{$H R I=R I(1-X)$}

O valor de $H A A\left(\mathrm{MJ} \mathrm{m}^{-2}\right)$ para cada planta foi calculado pela fórmula:

$$
H A A=\sum_{i=1}^{n-1} I_{i}\left(\left(\left(1-X_{i}\right)\left(1-\exp \left(-k L A I_{i}\right)\right)+\left(1-X_{i+1}\right)\left(1-\exp \left(-k L A I_{i+1}\right)\right)\right) / 2\right)\left(t_{i+1}-t_{i}\right)
$$




\subsubsection{Análises de regressão linear e não-linear}

Os dados foram analisados por meio de regressões lineares e não-lineares, utilizando o programa STATISTICA versão 5.0 (Statsoft, Tulsa, EUA). Os dados foram ajustados individualmente pelo modelo linear, $Y=B_{1} X$, onde $Y=$ componente de produção (rendimento, número de aquênios por planta, altura de planta, diâmetro de caule, diâmetro de capítulo, teor de óleo), $X=$ componente integral (AUDPC, HAD, $H A A)$ ou pontual $(X, H L A I, H R I)$ relacionado à doença ou à área foliar e $B_{1}=$ taxa da regressão linear. Também foram utilizados os modelos exponencial, $Y=B_{1} \exp \left(B_{2} X\right)$, e exponencial negativo, $Y=B_{1} \exp \left(-B_{2} X\right)$, onde $Y$ representa o componente de produção, $X$ representa o componente integral ou pontual relacionado à doença ou à área foliar, $B_{1}$ representa a interseção e $B_{2}$ representa a taxa da regressão.

\subsection{Resultados}

As plantas de girassol da semeadura de janeiro de 1999 não produziram e foram descartadas. Isso resultou em 175 plantas válidas para a primeira safra, 143 para a segunda e 232 para a terceira (Tabela 1).

A média dos valores de radiação solar de cada época de semeadura nas safras de 1997/1998, 1998/1999 e 1999/2000 variou de 15,62 a 21,55 MJ m² (Tabela 1). Os menores valores foram verificados no mês de janeiro de 1998. O escalonamento da semeadura em quatro épocas foi suficiente para proporcionar ampla variação na severidade da mancha de Alternaria nas plantas de girassol. As maiores médias de severidade e de $A U D P C$ foram verificadas nos meses de dezembro dos três anos (Tabela 1). Essas variáveis decresceram no mês de janeiro, já que muitas folhas senesceram devido à doença e não foram computadas na severidade. Plantas sadias $(A U D P C=0)$ só foram observadas nas semeaduras de outubro e novembro de 1999; neste primeiro mês, todas as plantas permaneceram sadias (Tabela 1 e Figura 1). A média de rendimento de grãos variou de 136,48 a 2540,30 kg/ha, para as semeaduras dos meses de dezembro de 1997 e outubro de 1998, respectivamente (Tabela 1). 
Observou-se relação entre $A U D P C$ e rendimento de aquênios para os experimentos das safras de 1998/1999 e 1999/2000 ( $R^{2}=0,79$ e 0,60, respectivamente) (Tabela 2 e Figura 1). A diminuição no rendimento foi descrita pelo modelo exponencial negativo $Y=B_{1} \exp \left(-B_{2} X\right)$, onde $Y=$ rendimento $(\mathrm{em} \mathrm{kg} / \mathrm{ha}), X=A U D P C, B_{1}=$ interseção e $B_{2}=$ taxa da regressão (Tabela 2). Não se verificou essa relação para o experimento de 1997/1998; o mesmo modelo aplicado a esse experimento resultou em $R^{2}=9 \%$ (Tabela 2 e Figura 1). Para os demais componentes de produção avaliados (número de aquênios, altura de planta, diâmetro de caule, diâmetro de capítulo e teor de óleo), não houve consistência na relação com $A U D P C$ nas três safras. O melhor ajuste pelo modelo exponencial negativo foi verificado para o componente diâmetro do capítulo, para o experimento de 1998/1999 $\left(R^{2}=0,92\right)$, mas esse mesmo modelo aplicado ao experimento da safra anterior resultou em $R^{2}$ de $3 \%$ (Tabela 2 e Apêndices 15 a 19).

Tabela 1. Radiação solar $\left(\mathrm{MJ} \mathrm{m}^{-2}\right)$, severidade da mancha de Alternaria (\%), área sob a curva de progresso da doença $(A U D P C)$ e rendimento de aquênios $(\mathrm{kg} / \mathrm{ha})$ de girassol, semeado em quatro épocas, em três safras consecutivas.

\begin{tabular}{|c|c|c|c|c|c|c|c|c|c|c|c|c|}
\hline \multirow[t]{2}{*}{ Época } & \multirow{2}{*}{$\begin{array}{l}\text { Plantas } \\
\text { válidas } \\
\quad *\end{array}$} & \multicolumn{2}{|c|}{$\begin{array}{c}\text { Radiação } \\
\text { solar }\left(\mathrm{MJ} \mathrm{m}^{-2}\right)\end{array}$} & \multicolumn{3}{|c|}{ Severidade (\%) } & \multicolumn{3}{|c|}{$\overline{A U D P C}$} & \multicolumn{3}{|c|}{ Rendimento (kg/ha) } \\
\hline & & Média & $\begin{array}{c}\text { Erro } \\
\text { padrão }\end{array}$ & Máx. & Média & $\begin{array}{c}\text { Erro } \\
\text { padrão }\end{array}$ & Máx. & Média & $\begin{array}{c}\text { Erro } \\
\text { padrão }\end{array}$ & Máx. & Média & $\begin{array}{c}\text { Erro } \\
\text { padrão }\end{array}$ \\
\hline \multicolumn{13}{|c|}{$1997 / 1998$} \\
\hline Out & 54 & 19,42 & 1,21 & 38,97 & 8,67 & 0,38 & 956,47 & 688,56 & 16,19 & 3425,93 & 1724,34 & 100,67 \\
\hline Nov & 74 & 20,80 & 0,94 & 38,52 & 6,87 & 0,31 & 733,96 & 530,28 & 10,61 & 1465,72 & 648,04 & 39,92 \\
\hline Dez & 22 & 17,28 & 1,33 & 38,68 & 13,36 & 0,93 & 934,17 & 828,35 & 15,09 & 280,97 & 136,48 & 17,76 \\
\hline Jan & 25 & 15,62 & 1,03 & 36,12 & 11,20 & 0,70 & 1071,22 & 717,80 & 36,04 & 829,19 & 168,30 & 35,38 \\
\hline \multicolumn{13}{|c|}{$1998 / 1999$} \\
\hline Out & 59 & 19,61 & 0,90 & 20,25 & 1,53 & 0,16 & 385,68 & 226,72 & 10,84 & 4633,10 & 2540,30 & 103,60 \\
\hline Nov & 58 & 19,48 & 1,09 & 38,03 & 6,83 & 0,39 & 388,44 & 307,04 & 5,53 & 2237,20 & 1062,96 & 48,47 \\
\hline Dez & 26 & 20,04 & 0,94 & 64,97 & 14,97 & 0,99 & 1298,82 & 849,05 & 27,60 & 769,06 & 331,72 & 41,52 \\
\hline \multicolumn{13}{|c|}{$1999 / 2000$} \\
\hline Out & 63 & 21,04 & 1,12 & 0,00 & 0,00 & 0,00 & 0,00 & 0,00 & 0,00 & 4196,67 & 2155,98 & 90,69 \\
\hline Nov & 63 & 21,55 & 0,77 & 34,72 & 0,99 & 0,17 & 225,67 & 57,83 & 7,10 & 3846,30 & 2181,12 & 88,64 \\
\hline Dez & 48 & 19,81 & 0,83 & 69,15 & 11,01 & 0,60 & 1118,05 & 601,28 & 25,21 & 2885,93 & 1178,35 & 109,52 \\
\hline Jan & 58 & 17,94 & 0,76 & 42,64 & 7,53 & 0,21 & 712,06 & 435,92 & 11,50 & 2335,27 & 1075,50 & 75,72 \\
\hline
\end{tabular}



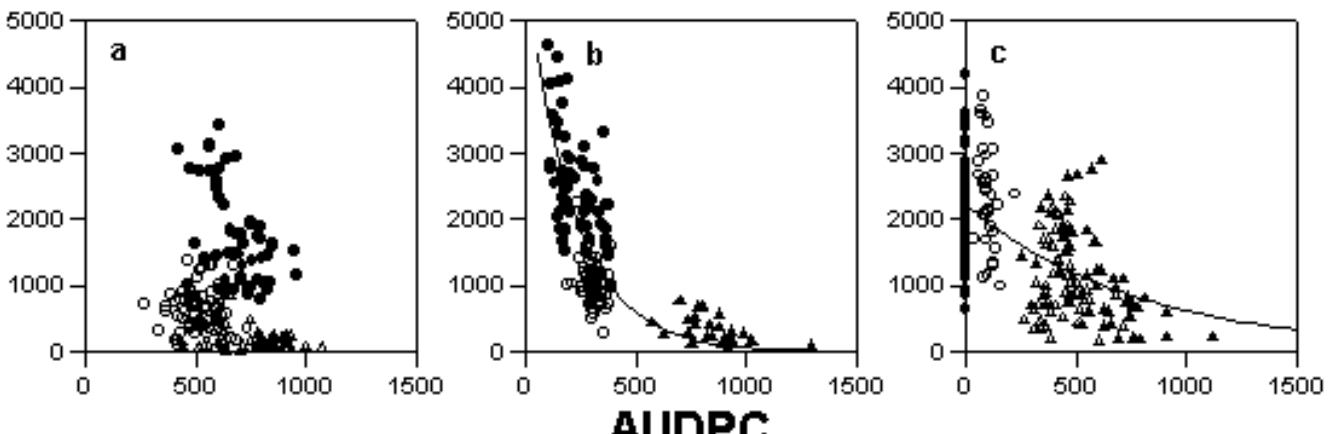

AUDPC
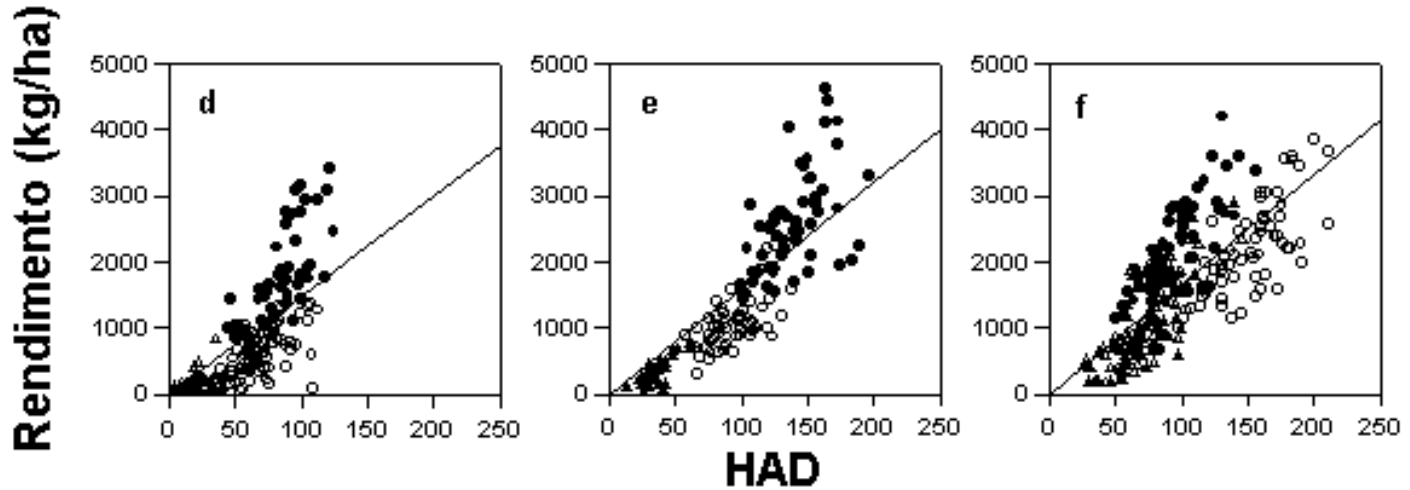

HAD
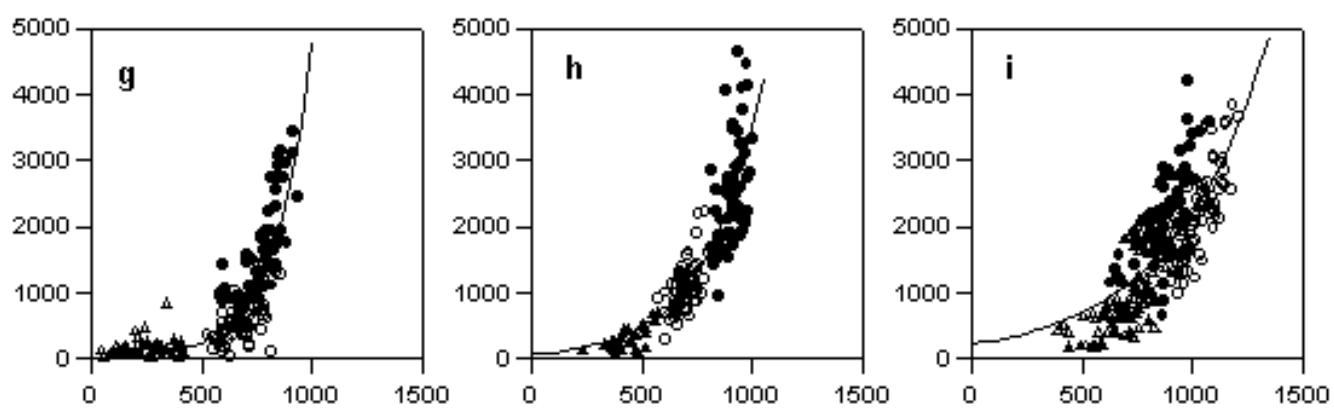

HAA

Figura 1 - AUDPC, HAD (em dias) ou HAA $\left(\mathrm{MJ} \mathrm{m}^{-2}\right)$ versus rendimento $(\mathrm{kg} / \mathrm{ha})$, para mancha de Alternaria em girassol, semeado em quatro épocas (outubro círculo cheio, novembro - círculo vazio, dezembro - triângulo cheio, janeiro triângulo vazio), em três safras consecutivas (1997/1998 - a, d, g; 1998/1999 b, e, h; 1999/2000 - c, f, i). Linhas representam ajuste dos modelos exponencial negativo (b, c), linear (d, e, f) e exponencial (g, h, i). 
Tabela 2. Coeficiente de determinação $\left(R^{2}\right)$ e parâmetros dos modelos de regressão $\left(B_{1}\right.$ e $B_{2}$ ) entre $A U D P C, H A D$ (em dias) ou $H A A\left(\mathrm{MJ} \mathrm{m}^{-2}\right)$ e componentes de produção, para mancha de Alternaria em girassol, em três safras consecutivas. Valores obtidos com todas as plantas semeadas em quatro épocas de cada safra.

\begin{tabular}{|c|c|c|c|c|c|c|c|c|c|}
\hline $\begin{array}{l}\text { Variáveis } \\
\text { dependentes }\end{array}$ & \multicolumn{3}{|c|}{ 1997/1998 } & \multicolumn{3}{|c|}{ 1998/1999 } & \multicolumn{3}{|c|}{$1999 / 2000$} \\
\hline \multicolumn{10}{|c|}{ Variável independente: $A U D P C$ - Modelo exponencial negativo } \\
\hline & $R^{2}$ & $B_{1}$ & $B_{2}$ & $R^{2}$ & $B_{1}$ & $B_{2}$ & $R^{2}$ & $B_{1}$ & $B_{2}$ \\
\hline Rendimento & 0,09 & 1159,67 & 0,00049 & 0,79 & 5645,25 & 0,00450 & 0,60 & 2203,99 & 0,00126 \\
\hline Número de aquênios & 0,08 & 769,46 & 0,00031 & 0,79 & 1696,71 & 0,00163 & 0,43 & 974,47 & 0,00080 \\
\hline Altura de planta & 0,43 & 270,84 & 0,00051 & 0,64 & 247,05 & 0,00026 & 0,06 & 190,79 & 0,00004 \\
\hline Diâmetro de caule & 0,54 & 36,49 & 0,00083 & 0,68 & 34,73 & 0,00048 & 0,23 & 23,27 & 0,00025 \\
\hline Diâmetro de capítulo & 0,03 & 17,12 & 0,00006 & 0,92 & 27,34 & 0,00114 & 0,42 & 19,80 & 0,00044 \\
\hline Teor de óleo & 0,01 & 34,76 & $-0,00001$ & 0,75 & 54,30 & 0,00119 & 0,15 & 44,39 & 0,00006 \\
\hline \multicolumn{10}{|c|}{ Variável independente: $H A D$ - Modelo linear (interseção forçada a zero) } \\
\hline & $R^{2}$ & $B_{1}$ & & $R^{2}$ & $B_{1}$ & & $R^{2}$ & $B_{1}$ & \\
\hline Rendimento & 0,73 & 14,98 & & 0,83 & 16,10 & & 0,74 & 16,66 & \\
\hline Número de aquênios & 0,68 & 10,01 & & 0,70 & 9,30 & & 0,45 & 7,70 & \\
\hline Diâmetro de capítulo & 0,39 & 0,24 & & - & - & & - & - & \\
\hline \multicolumn{10}{|c|}{ Variável independente: $H A A$ - Modelo exponencial } \\
\hline & $R^{2}$ & $B_{1}$ & $B_{2}$ & $R^{2}$ & $B_{1}$ & $B_{2}$ & $R^{2}$ & $B_{1}$ & $B_{2}$ \\
\hline Rendimento & 0,86 & 12,66 & 0,00594 & 0,89 & 65,34 & 0,00398 & 0,77 & 221,99 & 0,00229 \\
\hline Número de aquênios & 0,75 & 134,32 & 0,00237 & 0,83 & 242,59 & 0,00183 & 0,58 & 200,92 & 0,00159 \\
\hline Altura de planta & 0,80 & 133,99 & 0,00062 & 0,29 & 200,87 & 0,00015 & 0,59 & 112,76 & 0,00059 \\
\hline Diâmetro de caule & 0,54 & 15,46 & 0,00054 & - & - & - & 0,62 & 8,68 & 0,00106 \\
\hline Diâmetro de capítulo & 0,76 & 7,54 & 0,00125 & - & - & - & 0,69 & 6,77 & 0,00111 \\
\hline Teor de óleo & 0,66 & 25,26 & 0,00053 & 0,77 & 20,79 & 0,00080 & 0,14 & 47,49 & $-0,00010$ \\
\hline
\end{tabular}

-: modelos de regressão não se ajustaram aos dados

A relação $H A D$ x rendimento foi explicada pelo modelo de regressão linear com interseção forçada a zero, $Y=B_{1} X$, onde $Y=$ rendimento (em $\mathrm{kg} / \mathrm{ha}$ ) e $X=$ $H A D$ e $B_{1}=$ inclinação da reta (Tabela 2 e Figura 1 ). Neste caso, o rendimento aumentou linearmente com o aumento de $H A D$. O coeficiente de determinação da regressão foi 
elevado para as três safras $(0,73,0,83$ e 0,74$)$. O ajuste do modelo exponencial para os experimentos de 1997/1998 e 1998/1999 não aumentou consideravelmente o coeficiente de determinação (0,76 e 0,83, respectivamente). Para os outros componentes de produção, a relação com $H A D$ foi observada apenas para número de aquênios, nas três safras, $\left(0,45<R^{2}<0,70\right)$ e fracamente explicada para diâmetro de capítulo, em uma safra, não sendo possível estabelecer ajustes dos dados dos demais componentes, por regressão linear dos dados não transformados (Tabela 2 e Apêndices 15 a 19).

Dentre as variáveis integrais estudadas, a melhor relação com rendimento foi verificada para $H A A$ (Tabela 2 e Figura 1). O aumento no rendimento foi descrito pelo modelo exponencial $Y=B_{1} \exp \left(B_{2} X\right)$, onde $Y=$ rendimento (em $\left.\mathrm{kg} / \mathrm{ha}\right), X=H A A$, $B_{1}=$ interseção e $B_{2}=$ taxa da regressão (Tabela 2). Para os três experimentos, o coeficiente de determinação da regressão foi bastante elevado $\left(0,77<R^{2}<0,89\right)$. O mesmo modelo explicou a relação $H A A$ x componentes de produção, com coeficientes de determinação da regressão não-linear elevados em pelo menos um dos experimentos. Os maiores valores de $R^{2}$ verificados foram 0,83 para número de aquênios; 0,80 para altura de planta; 0,62 para diâmetro de caule; 0,76 para diâmetro de capítulo e 0,77 para teor de óleo (Tabela 2 e Apêndices 15 a 19).

As relações entre rendimento de aquênios e valores individuais de severidade, HLAI ou HRI, nas diferentes fases de desenvolvimento da cultura do girassol, também foram determinadas nas três safras de avaliação (Tabela 3, Figura 2 e Apêndices 20 a 28).

A relação entre severidade e rendimento de aquênios em cada fase de desenvolvimento foi descrita pelo modelo exponencial negativo $Y=B_{1} \exp \left(-B_{2} X\right)$, onde $Y=$ rendimento $(\mathrm{em} \mathrm{kg} / \mathrm{ha}), X=$ severidade $(\mathrm{em} \%), B_{1}=$ interseção e $B_{2}=$ taxa da regressão (Tabela 3). Para a safra 1997/1998, as taxas da regressão não-linear tenderam a se estabilizar a partir da fase R1 (entre 0,059 e 0,159). Esta estabilização também foi verificada a partir da fase R3 nos experimentos de 1998/1999 e 1999/2000 (entre 0,052 e 0,279 e entre 0,013 e 0,076, respectivamente) (Tabela 3 e Figura 2). Os coeficientes de determinação das regressões variaram entre 0,31 - 0,69; 0,81 - 0,86 e 0,33 - 0,64, para as três safras consecutivos (Tabela 3). 
Tabela 3. Coeficiente de determinação $\left(R^{2}\right)$ e parâmetros dos modelos de regressão $\left(B_{1} \mathrm{e}\right.$ $B_{2}$ ) entre severidade da mancha de Alternaria (\%), HLAI ou HRI $\left(\mathrm{MJ} \mathrm{m}^{-2}\right)$ e rendimento $(\mathrm{kg} / \mathrm{ha})$, nas diferentes fases de desenvolvimento de girassol, em três safras consecutivas. Valores obtidos com todas as plantas semeadas em quatro épocas de cada safra.

\begin{tabular}{|c|c|c|c|c|c|c|c|c|c|c|c|}
\hline \multicolumn{4}{|c|}{$1997 / 1998$} & \multicolumn{4}{|c|}{$1998 / 1999$} & \multicolumn{4}{|c|}{$1999 / 00$} \\
\hline \multicolumn{12}{|c|}{ Variável independente: Severidade - Modelo exponencial negativo } \\
\hline Fase & $R^{2}$ & $B_{1}$ & $B_{2}$ & Fase & $R^{2}$ & $B_{1}$ & $B_{2}$ & Fase & $R^{2}$ & $B_{1}$ & $B_{2}$ \\
\hline V10 & - & - & - & V4 & - & - & - & V10 & 0,45 & 1942,384 & 0,254 \\
\hline V15 & - & - & - & V10 & - & - & - & V16 & 0,47 & 1970,817 & 0,219 \\
\hline V21 & - & - & - & V18 & - & - & - & $\mathrm{R} 2$ & - & - & - \\
\hline $\mathrm{R} 1$ & 0,31 & 1544,990 & 0,112 & R1 & 0,82 & 2504,913 & 0,476 & $\mathrm{R} 3$ & 0,62 & 2136,316 & 0,145 \\
\hline R3 & 0,52 & 2391,300 & 0,159 & $\mathrm{R} 2$ & 0,82 & 2673,389 & 0,279 & R4 & 0,64 & 2159,638 & 0,076 \\
\hline R5.5 & 0,55 & 2277,439 & 0,118 & R3 & 0,81 & 2720,036 & 0,177 & R5.9 & 0,61 & 2151,104 & 0,065 \\
\hline R6 & 0,52 & 1801,449 & 0,071 & R5.5 & 0,83 & 2850,995 & 0,140 & R6 & 0,55 & 2098,799 & 0,048 \\
\hline R7 & 0,69 & 5768,575 & 0,079 & R6 & 0,84 & 2680,842 & 0,062 & $\mathrm{R} 7$ & 0,57 & 2117,121 & 0,036 \\
\hline $\mathrm{R} 8$ & 0,58 & 7246,420 & 0,059 & R7 & 0,86 & 4262,799 & 0,052 & $\mathrm{R} 8$ & 0,33 & 1927,844 & 0,013 \\
\hline \multicolumn{12}{|c|}{ Variável independente: $H L A I$ - Modelo linear (interseção forçada a zero) } \\
\hline Fase & $R^{2}$ & $B_{1}$ & & Fase & $R^{2}$ & $B_{1}$ & & Fase & $R^{2}$ & $B_{1}$ & \\
\hline V10 & 0,35 & 10076,47 & & V4 & - & - & & V10 & - & - & \\
\hline V15 & 0,51 & 2833,595 & & $\mathrm{~V} 10$ & - & - & & V16 & 0,51 & 2252,245 & \\
\hline V21 & 0,58 & 1351,448 & & V18 & - & - & & $\mathrm{R} 2$ & 0,61 & 1169,552 & \\
\hline $\mathrm{R} 1$ & 0,54 & 658,136 & & $\mathrm{R} 1$ & - & - & & $\mathrm{R} 3$ & 0,57 & 763,869 & \\
\hline R3 & 0,64 & 534,471 & & $\mathrm{R} 2$ & 0,50 & 683,185 & & R4 & 0,68 & 683,381 & \\
\hline R5.5 & 0,66 & 515,691 & & R3 & 0,70 & 630,841 & & R5.9 & 0,72 & 723,515 & \\
\hline R6 & 0,71 & 609,492 & & R5.5 & 0,82 & 674,054 & & R6 & 0,73 & 797,297 & \\
\hline R7 & 0,80 & 936,483 & & R6 & 0,89 & 736,375 & & R7 & 0,73 & 910,900 & \\
\hline $\mathrm{R} 8$ & 0,87 & 1732,835 & & R7 & 0,91 & 931,999 & & $\mathrm{R} 8$ & 0,52 & 1523,290 & \\
\hline \multicolumn{12}{|c|}{ Variável independente: $H R I$ - Modelo exponencial } \\
\hline Fase & $R^{2}$ & $B_{1}$ & $B_{2}$ & Fase & $R^{2}$ & $B_{1}$ & $B_{2}$ & Fase & $R^{2}$ & $B_{1}$ & $B_{2}$ \\
\hline V10 & 0,45 & 608,883 & 0,451 & V4 & - & - & - & V10 & 0,58 & 1181,012 & 0,083 \\
\hline V15 & - & - & - & V10 & - & - & - & V16 & 0,62 & 654,803 & 0,085 \\
\hline V21 & - & - & - & V18 & - & - & - & $\mathrm{R} 2$ & 0,57 & 248,045 & 0,129 \\
\hline $\mathrm{R} 1$ & - & - & - & $\mathrm{R} 1$ & 0,43 & 192,875 & 0,169 & R3 & - & - & - \\
\hline R3 & 0,77 & 2,735 & 0,387 & $\mathrm{R} 2$ & 0,81 & 19,436 & 0,281 & $\mathrm{R} 4$ & - & - & - \\
\hline R5.5 & 0,68 & 7,136 & 0,262 & R3 & 0,88 & 5,622 & 0,314 & R5.9 & - & - & - \\
\hline R6 & 0,77 & 6,385 & 0,284 & R5.5 & 0,57 & 148,627 & 0,123 & R6 & - & - & - \\
\hline $\mathrm{R} 7$ & 0,93 & 108,819 & 0,182 & R6 & 0,89 & 105,852 & 0,170 & R7 & 0,73 & 488,057 & 0,081 \\
\hline $\mathrm{R} 8$ & 0,89 & 325,655 & 0,169 & R7 & 0,80 & 97,081 & 0,244 & $\mathrm{R} 8$ & 0,69 & 864,032 & 0,065 \\
\hline
\end{tabular}

-: modelos de regressão não se ajustaram aos dados 

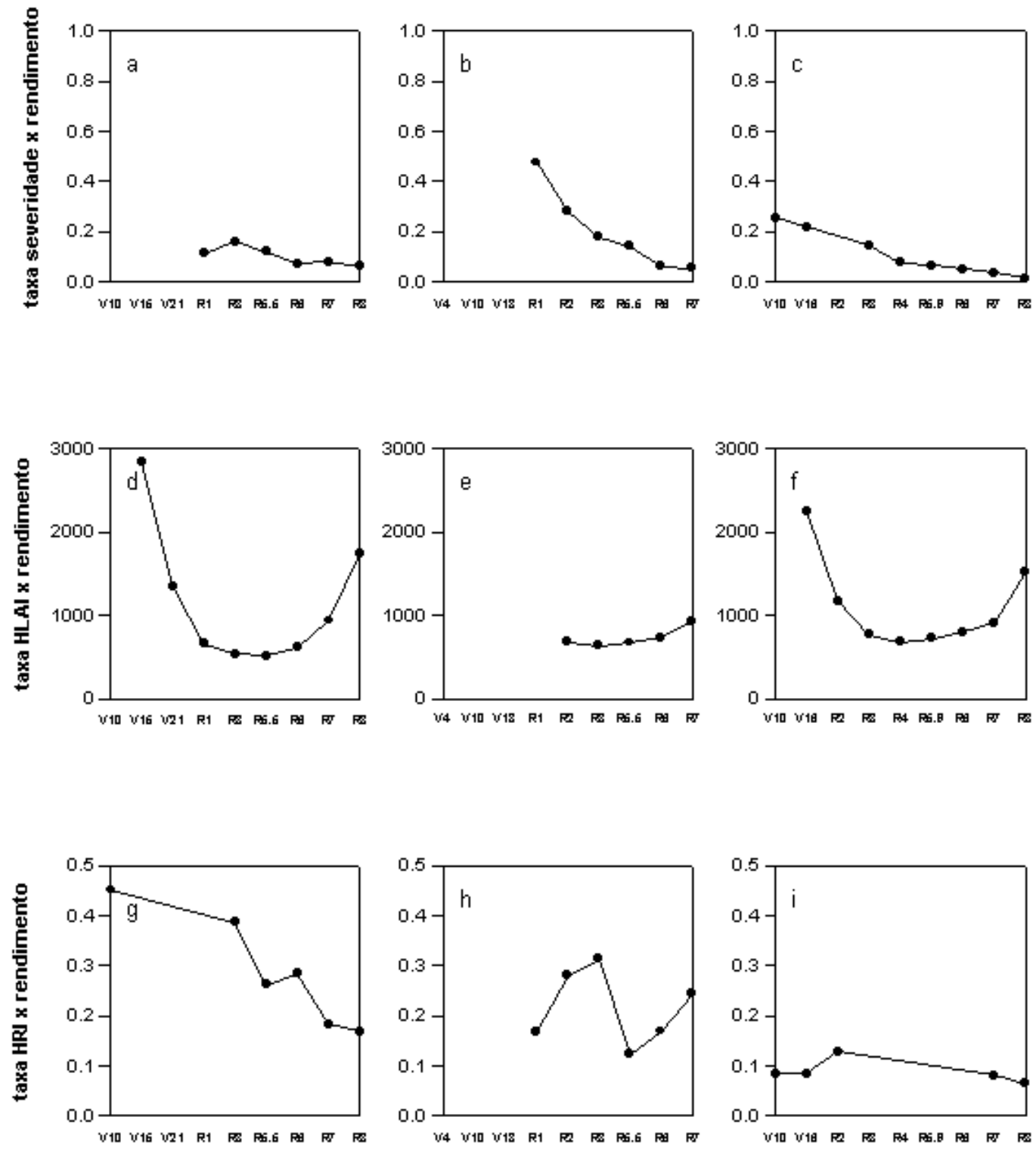

Fase de desenvolvimento

Figura 2 - Taxas das regressões entre severidade (\%) (a, b, c), HLAI (d, e, f) ou HRI (MJ $\left.\mathrm{m}^{-2}\right)(\mathrm{g}, \mathrm{h}, \mathrm{i})$ e rendimento $(\mathrm{kg} / \mathrm{ha})$, para mancha de Alternaria em girassol, em três safras consecutivas (1997/1998 - a, d, g; 1998/1999 - b, e, h; 1999/2000 $\mathrm{c}, \mathrm{f}, \mathrm{i})$ em diferentes fases de desenvolvimento da cultura. Taxas dos modelos exponencial negativo (a, b, c), linear (d, e, f) e exponencial (g, h, i). 
A relação linear com interseção forçada a zero entre $H L A I$ e rendimento também iniciou com taxas altas nas fases de desenvolvimento vegetativo, nos experimentos de 1997/1998 e 1999/2000 (1351 a 10076 e 2252, respectivamente), que se estabilizaram entre as fases R1 a R6 (515 a 658 e 683 a 797, respectivamente) e tornaram a subir a partir da fase R7. Para a safra de 1998/1999, a estabilização foi verificada entre as fases R2 e R6 (630 a 736), com tendência a subir a partir de R7 (Tabela 3 e Figura 2). Os coeficientes de determinação das regressões variaram entre 0,35 - 0,87; 0,50 - 0,91 e 0,51 - 0,73, para os experimentos de 1997/1998, 1998/1999 e 1999/2000, respectivamente (Tabela 3).

Observou-se relação entre $H R I$ avaliado nas diferentes fases de desenvolvimento do girassol e rendimento de aquênios. $O$ aumento no rendimento foi descrito pelo modelo exponencial $Y=B_{1} \exp \left(B_{2} X\right)$, onde $Y=$ rendimento (em $\left.\mathrm{kg} / \mathrm{ha}\right), X=$ $H R I, B_{1}=$ interseção e $B_{2}=$ taxa da regressão (Tabela 3). O coeficiente de determinação da regressão foi de $0,45<R^{2}<0,93$ para $1997 / 1998$; $0,43<R^{2}<0,89$ para $1998 / 1999$ e $0,57<R^{2}<0,73$ para 1999/2000 (Tabela 3). Diferentemente das taxas de severidade ou HLAI x rendimento, as taxas da regressão entre $H R I$ e rendimento foram bastante variáveis e não mostraram tendência de estabilização nas diferentes fases de desenvolvimento, para as três safras de avaliação (Figura 2).

Uma vez que o início da estabilização das taxas de regressão dos modelos que envolveram variáveis pontuais deu-se no início da fase reprodutiva do girassol, analisou-se separadamente a severidade das plantas marcadas em cada fase de desenvolvimento reprodutivo (Apêndices 20 a 28). A relação entre rendimento de aquênios e valores individuais de severidade na fase de desenvolvimento R3, nas três safras de avaliação, é apresentada na Figura 3. Os coeficientes de determinação das regressões foram de 0,52, 0,81 e 0,62, para os experimentos de 1997/1998, 1998/1999 e 1999/2000, respectivamente (Tabela 3). Verificou-se que plantas que apresentaram severidade maior que $10 \%$ nessa fase obtiveram rendimentos inferiores a $500 \mathrm{~kg} / \mathrm{ha}$, para as três safras, independentemente da época de semeadura. 

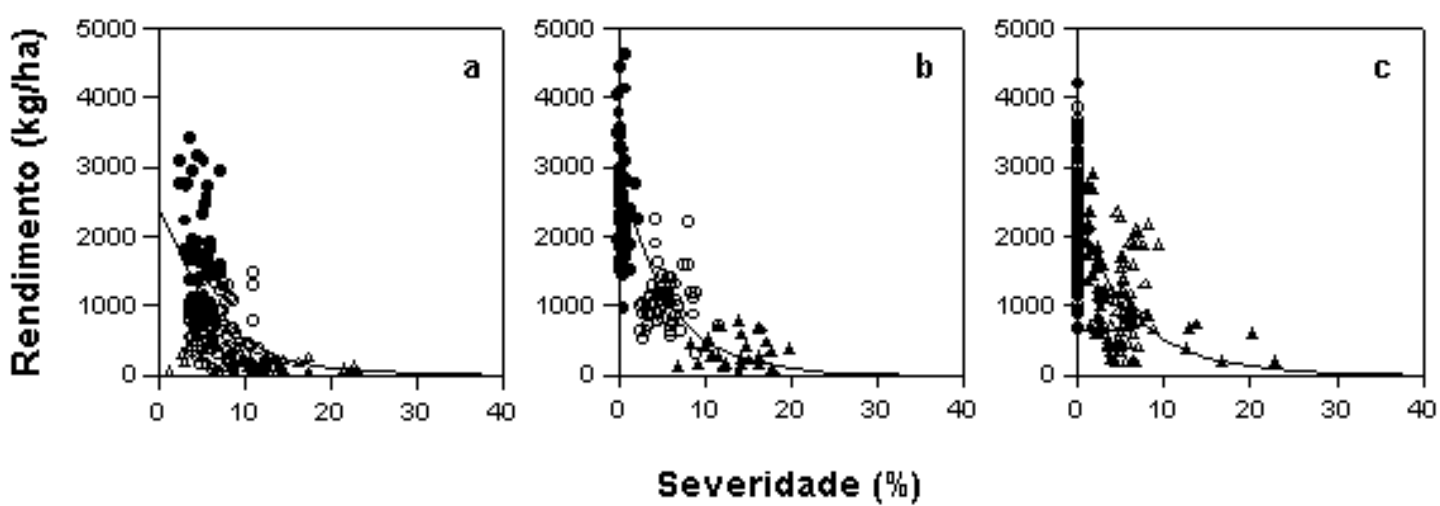

Severidade $(\%)$

Figura 3 - Severidade (\%) na fase de desenvolvimento R3 versus rendimento ( $\mathrm{kg} / \mathrm{ha})$, para mancha de Alternaria em girassol, semeado em quatro épocas (outubro círculo cheio, novembro - círculo vazio, dezembro - triângulo cheio, janeiro triângulo vazio), em três safras consecutivas (1997/1998 - a; 1998/1999 - b; 1999/2000 - c). Linhas representam ajuste do modelo exponencial negativo.

\subsection{Discussão}

A escolha de plantas semeadas em quatro épocas para a avaliação de danos da mancha de Alternaria em girassol atingiu o objetivo de representar a maior variação possível da severidade da doença, bem como a presença de plantas sadias, imprescindível para trabalhos de quantificação de danos (Bergamin Filho \& Amorim, 1996).

A relação entre $A U D P C$ e rendimento de aquênios foi observada para os experimentos das safras de 1998/1999 e 1999/2000 e não foi verificada para o experimento de 1997/1998. O fracasso na correlação entre variáveis de doença e produção em alguns patossistemas não é surpreendente para Waggoner \& Berger (1987), que postulam ser a produção vegetal função da área foliar sadia do hospedeiro e não da área destruída pelo patógeno. Em culturas de hábito de crescimento indeterminado, como o feijoeiro, não há relação entre área sadia e área doente e, conseqüentemente, 
entre doença e produção (Amorim et al., 1995; Bergamin Filho et al., 1997). Em culturas onde o número de folhas é fixo, como nos cereais, área foliar sadia e área foliar doente são altamente correlacionadas, razão porque a relação entre doença e produção tem sido usada com êxito em cereais (Amorim et al., 1995). Assim, o fato do girassol ser de hábito de crescimento determinado pode explicar a relação entre a variável de doença $(A U D P C)$ e a produção, já que área sadia e doente também são relacionadas.

Para as duas safras, a diminuição no rendimento atribuída à $A U D P C$ foi razoavelmente descrita pelo modelo exponencial negativo $\left(R^{2}\right.$ de 0,79 e 0,60$)$. Os coeficientes de determinação foram elevados, considerando se tratar de experimentos de campo (Campbell \& Madden, 1990). Johnson (1987) teoriza que curvas desse formato indicam que a eficiência no uso da radiação $(R U E)$ dos tecidos remanescentes verdes do hospedeiro, aparentemente sadios, está afetada pelo patógeno (Bastiaans, 1991). De fato, Calvet (2001) analisou a influência da mancha de Alternaria nas áreas verdes remanescentes do tecido foliar de plantas de girassol e observou redução das taxas fotossintéticas dos tecidos verdes remanescentes das folhas doentes, comprovando-se que existe "lesão virtual", ou seja, uma área verde ao redor da lesão visível em que a fotossíntese é reduzida, para o patossistema girassol - A. helianthi. Os valores da relação entre lesão virtual e lesão visual (â) encontrados variaram de 1,4 a 4,7 nas diferentes épocas de semeadura avaliadas, indicando que a época de semeadura tem influência sobre a severidade da doença. A autora também observou que folhas ainda sem lesões de plantas doentes apresentaram comprometimento fotossintético. Assim, a mancha de Alternaria afeta o girassol não apenas pela redução em $L A I$ e conseqüentemente em $R I$, mas também em $R U E$.

Não houve consistência na relação com $A U D P C$ para número de aquênios, altura de planta, diâmetro de caule, diâmetro de capítulo e teor de óleo, nas três safras de avaliação. Esses resultados são concordantes aos obtidos por Carson (1987), que verificou que as avaliações de severidade da doença e área sob a curva de progresso da mancha de Alternaria, causada por Alternaria zinniae, não foram consistentemente correlacionadas com outros componentes de produção, além de rendimento de grãos, como teor de óleo e peso de sementes de girassol. 
A variável de área foliar $H A D$ apresentou boa relação linear com rendimento, com altos valores de coeficiente de determinação $(>0,73)$. Essa relação linear já havia sido observada para outra espécie de Alternaria, no patossistema A. solani - batata (Johnson et al., 1987). Em girassol, a duração da área foliar (LAD) foi altamente correlacionada com rendimento, em condições de seca (Miller \& Fick, 1997).

$H A A$ foi a variável integral de área foliar que obteve a melhor relação com rendimento e outros componentes de produção avaliados. A relação não-linear entre $H A A$ e produção, evidenciando acentuada tendência exponencial, já foi amplamente verificada para doenças do feijoeiro (Bergamin Filho \& Amorim, 1996; Bergamin Filho et al., 1997). Neste caso, a forma da curva é função de vários fatores, especialmente HLAI, coeficiente de extinção e hábito de crescimento do hospedeiro (Bergamin Filho et al., 1997).

A clara relação existente entre $A U D P C, H A D$ ou $H A A$ e produção tem importante implicação no desenvolvimento de sistemas de manejo integrado de pragas e doenças. O inconveniente do uso de uma variável integral como variável chave num sistema desse tipo é que sua estimativa, usualmente, só pode ser feita após diversas avaliações, durante um período de tempo relativamente longo (nove avaliações em cerca de 90 dias, nestes experimentos), fato que praticamente impede seu uso no processo de tomada de decisão. Neste contexto, o ideal seria uma variável de quantificação instantânea, que fornecesse a mesma confiabilidade, ou quase, de uma variável integral. Assim, a decisão no manejo poderia ser tomada após uma única avaliação, no ponto crítico (Bergamin Filho \& Amorim, 1996).

As relações entre rendimento de aquênios e valores individuais de severidade, HLAI ou HRI, nas diferentes fases de desenvolvimento da cultura do girassol, indicam resultados promissores no estabelecimento de um limiar de dano para a mancha de Alternaria, utilizando uma variável de quantificação instantânea.

As taxas da relação linear com interseção forçada a zero entre $H L A I$ e rendimento estabilizaram-se a partir da fase de desenvolvimento reprodutivo R1, com valores médios de 662, 579 e 742 para as três safras. Isso indica que cada unidade do índice de área foliar nessas fases corresponde a um aumento na produção da ordem de 
$500 \mathrm{~kg} / \mathrm{ha}$. Essa variável também apresentou relação linear com produção para o patossistema Uromyces appendiculatus - feijoeiro, com estabilização semelhante à encontrada no presente trabalho. Assim, foi considerada uma variável adequada para ser usada no processo de tomada de decisão para esse patossistema, dentro de um sistema de manejo integrado de pragas e doenças do feijoeiro (Bergamin Filho \& Amorim, 1996). Apesar dos altos coeficientes de determinação observados na regressão não-linear, utilizando o modelo exponencial, as taxas da regressão entre $H R I$ e rendimento foram bastante variáveis e não mostraram tendência de estabilização nas diferentes fases de desenvolvimento, não sendo adequada para uso na tomada de decisão para o manejo da mancha de Alternaria. Para duas safras, a taxa da regressão entre HRI e rendimento foi influenciada pela época de semeadura (Apêndices 27 e 28).

No presente trabalho, as taxas da relação negativa entre severidade e rendimento de aquênios em cada fase de desenvolvimento também tenderam a se estabilizar a partir das fases de desenvolvimento reprodutivo. A relação entre produtividade e severidade da doença (\%) também foi verificada em epidemias da mancha de Alternaria em girassol, na Índia, em experimentos conduzidos entre 1991 a 1995, com valores de coeficiente de determinação variando entre 0,88 e 0,96 (Chattopadhyay, 1999; Srinivas et al., 1998). O início da fase reprodutiva também pareceu ser crítico para a produção nesses experimentos, já que a infecção ocorrida entre o final da fase vegetativa e a emissão do botão floral resultou em maiores danos à produtividade (Chattopadhyay, 1999; Srinivas et al., 1998). Deste modo, a severidade no início da fase de reprodução pode ser usada como uma variável independente para um sistema de manejo da mancha de Alternaria em girassol.

Analisando a relação entre rendimento de aquênios e valores individuais de severidade nas diferentes fases de desenvolvimento, optou-se por investigar detalhadamente a fase R3, caracterizada pelo alongamento do broto floral, já que esta situa-se no início do desenvolvimento reprodutivo e foi avaliada nas três safras. Nessa fase, verificou-se que plantas que apresentaram severidade maior que $10 \%$ obtiveram rendimentos inferiores a $500 \mathrm{~kg} / \mathrm{ha}$, para as três safras, independentemente da época de 
semeadura. Cada unidade porcentual de severidade acrescida representou, em média, $16 \%$ de diminuição no rendimento.

Este fato sugere um limiar de dano, ou seja, plantas que apresentem 10\% de severidade da mancha de Alternaria na fase R3 já estão com a produção seriamente comprometida. Considerando que o custo variável para produção de girassol no Brasil foi estimado no equivalente a um rendimento de $1333 \mathrm{~kg} / \mathrm{ha}$ (Castro et al., 1996), a produção de uma lavoura afetada pela doença a esse nível de severidade sequer pagaria esse custo, resultando em prejuízo para o agricultor.

As medidas de controle da mancha de Alternaria têm caráter principalmente preventivo e não devem ser utilizadas de forma isolada. O controle efetivo de doenças baseia-se num programa integrado de medidas, que incluem principalmente a resistência genética e a escolha da época de semeadura. A resistência genética às doenças é altamente desejável, pois não onera diretamente o custo de produção e, muitas vezes, pode dispensar outras medidas de controle (Leite, 1997). Estudos sobre o comportamento de genótipos e trabalhos de melhoramento visando resistência devem incluir a avaliação da severidade da mancha de Alternaria na fase de desenvolvimento $\mathrm{R} 3$, com o auxílio de uma escala diagramática desenvolvida e validada para a doença (Leite \& Amorim, 2002).

Além disso, as épocas de semeadura de dezembro e janeiro resultaram em um maior número de plantas com severidade maior que $10 \%$ em $\mathrm{R} 3$, em pelo menos duas safras de avaliação, o que confirma não serem meses adequados para semeadura do girassol em Londrina, PR. De fato, a época recomendada para semeadura de girassol no Estado do Paraná é de agosto a meados de outubro (Castro et al., 1996). Do mesmo modo, pesquisas sobre a época de semeadura para as diferentes regiões devem considerar, além dos riscos de ocorrência de déficit hídrico (Farias et al., 2001), a avaliação da severidade da mancha de Alternaria na fase de desenvolvimento R3. 


\subsection{Conclusões}

A relação entre severidade e rendimento de aquênios em cada fase de desenvolvimento da cultura do girassol é descrita pelo modelo exponencial negativo.

Plantas com no mínimo $10 \%$ de severidade da mancha de Alternaria na fase R3 apresentam rendimentos inferiores a $500 \mathrm{~kg} / \mathrm{ha}$.

Dentre as variáveis integrais, $H A A$ é a que apresenta melhor relação com rendimento, descrita pelo modelo exponencial. 


\section{CONCLUSÕES GERAIS}

As condições ótimas para o estabelecimento da mancha de Alternaria em

girassol situam-se em $25{ }^{\circ} \mathrm{C}$ e $24 \mathrm{~h}$ de molhamento foliar. Essas condições devem ser consideradas na escolha de épocas de semeadura para cada região.

A severidade pode ser usada como uma variável independente num sistema de manejo da mancha de Alternaria em girassol, para a estimativa de danos provocados pela doença. Essa variável também pode ser utilizada na seleção de plantas resistentes. Nesse caso, o limiar de $10 \%$ de severidade na fase de desenvolvimento R3 deve ser usado para descartar materiais suscetíveis. 


\section{REFERÊNCIAS BIBLIOGRÁFICAS}

ABBAS, H.K.; EGLEY, G.H.; PAUL, R.N. Effect of conidia production temperature on germination and infectivity of Alternaria helianthi. Phytopathology, v.85, p.677-682, 1995.

ALLEN, S.J.; BROWN, J.F.; KOCHMAN, J.K. Effects of leaf age, host growth stage, leaf injury, and pollen on the infection of sunflower by Alternaria helianthi. Phytopathology, v.73, p.896-898, 1983a.

ALLEN, S.J.; BROWN, J.F.; KOCHMAN, J.K. Effects of temperatures, dew period, and light on the growth and development of Alternaria helianthi. Phytopathology, v.73, p.893-896, 1983b.

ALLEN, S.J.; KOCHMAN, J.K.; BROWN, J.F. Losses in sunflower yield caused by Alternaria helianthi in southern Queensland. Australian Journal of Experimental Agriculture and Animal Husbandry, v.21, p.98-100, 1981.

ALMEIDA A.M.R.; MACHADO, C.C.; CARRÃO-PANIZZI, M.C. Doenças do girassol; descrição de sintomas e metodologia para levantamento. Londrina: EMBRAPA, CNPSo, 1981. 24 p. (EMBRAPA. CNPSo. Circular Técnica, 6).

AMORIM, L. Avaliação de doenças. In: BERGAMIN FILHO, A.; KIMATI, H.; AMORIM, L. Manual de fitopatologia: princípios e conceitos. São Paulo: Agronômica Ceres, 1995. v.1, p.331-341. 
AMORIM, L.; BERGAMIN FILHO, A.; GODOY, C.V.; IAMAUTI, M.T.; NUNES, W.M.; CARNEIRO, S.M.T.P.G. Avaliação de danos na cultura do feijoeiro. Summa Phytopathologica, v.21, p.82-84, 1995.

AMORIM, L.; BERGAMIN FILHO, A.; PALAZZO, D.; BASSANEZI, R.B.; GODOY, C.V.; TORRES, G.A.M. Clorose variegada dos citros: uma escala diagramática para avaliação da severidade da doença. Fitopatologia Brasileira, v.18, p.174-180, 1993.

ANAHOSUR, K.H. Alternaria helianthi. CMI Descriptions of Pathogenic Fungi and Bacteria, n.582, 1978. 2p.

BALASUBRAHMANYAM, N.; KOLTE, S.J. Effect of Alternaria blight on yield components, oil content and seed quality of sunflower. Indian Journal of Agricultural Sciences, v.50, n.9, p.701-706, 1980.

BASSANEZI, R.B., AMORIM, L., BERGAMIN FILHO, A.; HAU, B. Effects of bean line pattern mosaic virus on the monocyclic components of rust and angular leaf spot of Phaseolus bean at different temperatures. Plant Pathology, v.47, p.289-298, 1998.

BASTIAANS, L. Ratio between virtual and visual lesion size as a measure to describe reduction in leaf photosynthesis of rice due to leaf blast. Phytopathology, v.81, p.611-615, 1991.

BERGAMIN FILHO, A. Avaliação de danos e perdas. In: BERGAMIN FILHO, A.; KIMATI, H.; AMORIM, L. Manual de fitopatologia: princípios e conceitos. São Paulo: Agronômica Ceres, 1995. v.1, p.672-690. 
BERGAMIN FILHO, A.; AMORIM, L. Doenças de plantas tropicais: epidemiologia e controle econômico. São Paulo: Agronômica Ceres, 1996. 299p.

BERGAMIN FILHO, A.; CARNEIRO, S.M.T.P.G.; GODOY, C.V.; AMORIM, L.; BERGER, R.D.; HAU, B. Angular leaf spot of Phaseolus beans: relationships between disease, healthy leaf area, and yield. Phytopathology, v.87, p.506-515, 1997.

BERGER, R.D. Measuring disease intensity. In: TENG, P.S.; KRUPA, S.V. (Ed.). Crop loss assessment. Saint Paul: University of Minnesota, 1980. p.28-31.

BERGER, R.D. Comparison of the gompertz and logistic equations to describe plant disease progress. Phytopathology, v.71, p.717-719, 1981.

BERGER, R.D. The analysis of the effects of control measures on the development of epidemics. In: KRANZ, J.; ROTEM, J. (Ed.) Experimental techniques in plant disease epidemiology. Heidelberg: Springer-Verlag, 1988. cap.9, p.137-151.

BORKAR, S.G.; PATIL, B.S. Epidemiology of Alternaria leaf spot disease of sunflower. Indian Phytopathology, v.48, p.84-85, 1995.

CALVET, N. P. Lesão virtual causada pela mancha de Alternaria helianthi em diferentes genótipos de girassol (Helianthus annuus L.), e sua relação com a fotossíntese. Piracicaba, 2001. 48p. Dissertação (Mestrado) - Escola Superior de Agricultura “Luiz de Queiroz”, Universidade de São Paulo.

CAMPBELL, C.L.; MADDEN, L.V. Introduction to plant disease epidemiology. New York: John Willey, 1990. 532p. 
CARNEIRO, L.C.; AMORIM, L. Influência da temperatura e do molhamento foliar no monociclo do "mal-de-sete-voltas" da cebola. Fitopatologia Brasileira, v.24, n.3, p.422-427, 1999.

CARSON, M.L. Epidemiology and yield losses associated with alternaria blight of sunflower. Phytopathology, v.75, p.1151-1156, 1985.

CARSON, M.L. Effects of two foliar pathogens on seed yield of sunflower. Phytopathology, v.71, p.549-551, 1987.

CARVALHO, V.P.; BERGAMIN FILHO, A.; AMORIM, L.; ALMEIDA, A.M.R.; FARIAS， J.R.B.; CASTRO， C.; CASTIGLIONI， V.B.R.; LEITE， R.M.V.B.C. Desenvolvimento da mancha de alternária em genótipos de girassol em diferentes épocas de semeadura. In: REUNIÃO NACIONAL DE PESQUISA DE GIRASSOL, 11., Goiânia, 1995. Resumos. Goiânia: EMBRAPA, CNPAF, 1995. p.77.

CASTIGLIONI, V.B.R.; BALlA, A.; CASTRO, C. de; SILVEIRA, J.M. Fases de desenvolvimento da planta de girassol. Londrina: EMBRAPA, CNPSo, 1994. 24p. (EMBRAPA. CNPSo. Documentos, 58).

CASTRO, C. de; CASTIGLIONI, V.B.R.; BALLA, A.; LEITE, R.M.V.B.C.; KARAM, D.; MELLO, H.C.; GUEDES, L.C.A.; FARIAS, J.R.B. A cultura do girassol. Londrina: EMBRAPA, CNPSo, 1996. 38p. (EMBRAPA. CNPSo. Circular técnica, 13).

CHATTOPADHYAY, C. Yield loss attributable to Alternaria blight of sunflower (Helianthus annuus L.) in India and some potentially effective control measures. International Journal of Pest Management, v.45, n.1, p.15-21, 1999. 
DALL'AGNOL, A.; CASTIGLIONI, V.B.R.; TOLEDO, J.F.F. A cultura do girassol no Brasil. In: PUIGNAU, J. (Ed.) Mejoramiento genético de girasol. Montevideo: IICA, PROCISUR, 1994. p.37-41. (Diálogo, 41).

DAS, N.D.; SANKAR, G.R.M.; SRIVATSAVA, N.N. Studies on the progression of Alternaria blight disease, Alternaria helianthi (Hansf.) Tubaki and Nishihara of sunflower. Annals of Plant Protection Sciences, v.6, n.2, p.209-211, 1998.

DAVET, P.; PÉRÈS, A.; REGNAUlT, Y.; TOURVIEILlE, D.; PENAUD, A. Les maladies du tournesol. Paris: CETIOM, 1991. 72p.

DAVID, J.C. Alternaria zinniae. CMI Descriptions of Pathogenic Fungi and Bacteria, n.1077, 1991. 2p.

DRAPER, N.R.; SMITH, H. Applied regression analysis. 3. ed. New York: John Wiley, 1998. 706p.

DUDIENAS, C.; UNGARO, M.R.G.; MORAES, S.A. Alternaria disease development under tropical conditions. Helia, v.21, n.29, p.63-72, 1998.

EMPRESA BRASILEIRA DE PESQUISA AGROPECUÁRIA. Centro Nacional de Pesquisa de Soja. Resultados de pesquisa de girassol: 1983. Londrina: EMBRAPA, CNPSo, 1983. 86p.

ESTADOS UNIDOS. Department of Agriculture. Foreign Agricultural Service. Oilseeds: world market and trade. Washington, 2002. 43p. (Circular Series, FOP 05-02). 
FARIAS, J.R.B.; ALMEIDA, I.R.; BUCHE, M.V.; ZAMPAR, C.E.; SILVA, F.A.M. Caracterização da aptidão climática de regiões para o cultivo do girassol. In: HOFFMANN-CAMPO, C.B.; SARAIVA, O.F. (Org.) Resultados de pesquisa da Embrapa Soja - 2000: girassol e trigo. Londrina: Embrapa Soja, 2001. p.21-23. (Documentos, 165).

GAUNT, R.E. The relationship between plant disease severity and yield. Annual Review of Phytopathology, v.33, p.119-144, 1995.

GHEMAWAT, M.S.; SAHU, B.K.; AGRAWAT, J.M. Yield losses in sunflower due to Alternaria helianthi (Hansf.) Tubaki and Nishihara. Archive für Phytopathologie und Pflanzenschutz, v.25, p.541-544, 1989.

GODOY, C.V.; AMORIM, L.; BERGAMIN FILHO, A. Influência da duração do molhamento foliar e da temperatura no desenvolvimento da ferrugem do milho causada por Puccinia polysora. Fitopatologia Brasileira, v.24, n.2, p.160165.1999.

GODOY, C.V.; CARNEIRO, S.M.T.P.G.; IAMAUTI, M.T, PRIA, M.D.; AMORIM, L.; BERGER, R.D.; BERGAMIN FILHO, A. Diagrammatic scales for bean diseases: development and validation. Zeitschrift für Pflanzenkrankheiten und Pflanzenschutz, v.104, n.4, p.336-345, 1997.

GODOY, J.R. de; FERNANDES, N.G. Alternaria helianthi (Hansf.) Tubaki \& Nishihara em girassol (Helianthus annиus L.): influência da idade da planta na suscetibilidade e na infecção das sementes. Summa Phytopathologica, v.11, p.186-197, 1985a.

GODOY, J.R. de; FERNANDES, N.G. Epidemiologia da mancha de alternária (Alternaria helianthi (Hansf.) Tubaki \& Nishihara), em girassol (Helianthus annuus L). Summa Phytopathologica, v.11, p.198-214, 1985b. 
GRANLUND, M.; ZIMMERMAN, D.C. Oil content of sunflower seeds as determined by wide-line nuclear magnetic resonance. Proceedings of North Dakota Academy of Sciences, v.27, p.128-133, 1975.

GULYA, T.; RASHID, K.Y.; MASIREVIC, S.M. Sunflower diseases. In: SCHNEITER, A.A. Sunflower technology and production Madison: American Society of Agronomy, 1997. p.263-379.

HAU, B.; KRANZ, J. Mathematics and statistics for analyses in epidemiology. In: KRANZ, J. (Ed.) Epidemics of plant diseases: mathematical analyses and modeling. Berlin: Springer-Verlag, 1990. p.12-52.

HORSFALL, J.G.; BARRATT, R.W. An improved grading system for measuring plant disease. Phytopathology, v.35, p.655, 1945.

ISLAM, U.; MARIC, A. Contribution to the studies on biology, epidemiology and resistance of sunflower to Alternaria helianthi (Hansf.) Taub. Nish. Zastita Bilja, v.31, p.35-49, 1980.

JAMES, W.C. Assessment of plant diseases and losses. Annual Review of Phytopathology, v.12, p.27-48, 1974.

JOHNSON, K. B. Defoliation, disease, and growth: a reply. Phytopathology, v.77, p.1495-1497, 1987.

JOHNSON, K. B.; TENG, P. S.; RADCLIFFE, E. B. Analysis of potato foliage losses caused by interacting infestations of early blight, Verticillium wilt, and potato leafhopper; and the relationship to yield. Journal of Plant Disease Protection, v.94, p.22-33, 1987. 
KONG, G.A.; KOCHMAN, J.K.; BROWN, J.F. A greenhouse assay to screen sunflower for resistance to Alternaria helianthi. Annals of Applied Biology, v.127, p.463-478, 1995.

KRANZ, J. Measuring plant disease. In: KRANZ, J.; ROTEM, J. (Ed.) Experimental techniques in plant disease epidemiology. Berlin: Springer, 1988. p.35-50.

KRANZ, J.; JÖRG, E. The synecological approach in plant disease epidemiology. Review of Tropical Plant Pathology, v.6, p.27-38, 1989.

KUMAR, R.; SINGH, S.B. Influence of weather factors on Alternaria leaf spot development in sunflower. Indian Journal of Mycology and Plant Pathology, v.26, n.2, p.196-198, 1996.

LAGOPODI, A.L.; THANASSOULOPOULOS, C.C. Alternaria alternata f.sp. helianthina: a new pathotype of the fungus causing Alternaria leaf spot to sunflower. Journal of Phytopathology, v.144, p.571-573, 1996.

LEITE, R.M.V.B.C. Crescimento e esporulação de Alternaria helianthi em diferentes meios de cultura. Fitopatologia Brasileira, v.21, p.365, 1996. Suplemento. /Apresentado ao XXIX Congresso Brasileiro de Fitopatologia, Campo Grande, 1996 - Resumo/

LEITE, R.M.V.B.C. Doenças do girassol. Londrina: EMBRAPA, CNPSo, 1997. 68p. (Circular Técnica, 19).

LEITE, R.M.V.B.C.; AMORIM, L. Elaboração e validação de escala diagramática para mancha de Alternaria em girassol. Summa Phytopathologica, v.28, n.1, p.14-19, 2002. 
LEITE, R.M.V.B.C.; TREZZI, M.M.; OLIVEIRA, M.F.; ARIAS, C.A.A.; CASTIGLIONI, V.B.R. Reaction of sunflower genotypes to Alternaria helianthi, in the State of Paraná, Brazil. Helia, v.22, n.31, p.151-156, 1999.

MASIREVIC, S. Proposed methodologies for inoculation of sunflower with Alternaria helianthi and for disease assessment. In: ILIESCU, H. Proposed methodologies for inoculation of sunflower with different pathogens and for disease assessment. Bucharest: FAO European Research Network on Sunflower, 1995. p.25-28.

MILLER, J.F.; FICK, G.N. The genetics of sunflower. In: SCHNEITER, A.A. Sunflower technology and production. Madison: American Society of Agronomy, 1997. p.441-495.

MONTEITH, J.L. Light interception and radiative exchange in crop stands. In: EASTIN, J.D.; HASKINS, F.A.; SULlIVAN, C.Y.; VAN BAVEL, C.H.M.; DINAUER, R.C. Physiological aspects of crop yield. Madison: American Society of Agronomy; Crop Science Society of America, 1969. p.89-115.

MONTEITH, J. L. Climate and the efficiency of crop production in Britain. Philosophical Transactions of the Royal Society of London, v.281, p.277-294, 1977.

MUKEWAR, P.M.; GERA, S.D. Carrots - an excellent substrate for growth and sporulation of Alternaria helianthi. Current Science, v.49, p.272, 1980.

NAGARAJU, A.J.; JAGADISH, B.N.; VIRUPAKSHAPPA, K. Reaction of cytoplasmic male sterile and restorer lines of sunflower to Alternaria helianthi. Indian Phytopathology, v.45, p.372-373, 1992. 
NUTTER JR., F.W.; SCHULTZ, P.M. Improving the accuracy and precision of disease assessments: selection of methods and use of computer-aided training programs. Canadian Journal of Plant Pathology, v.17, p.174-184, 1995.

NUTTER JR., F.W.; GLEASON, M.L.; JENCO, J.H.; CHRISTIANS, N.C. Assessing the accuracy, intra-rater repeatability, and inter-rater reliability of disease assessment systems. Phytopathology, v.83, p.806-812, 1993.

PEREYRA, V.; ESCANDE, A.R. Enfermedades del girasol en la Argentina: manual de reconocimiento. Balcarce: INTA, 1994. 113p.

PEREYRA, V.R.; FARIZO, C.; CARDINALI, F. Estimation of leaf area on sunflower plants. In: INTERNATIONAL SUNFLOWER CONFERENCE, 8., Minneapolis, 1978. Proceedings. Minneapolis: International Sunflower Association, 1978. p.21-23.

RAVIKUMAR, R.L.; DODDAMANI, I.K.; KULLARNI, M.S. Reaction of selected germplasm lines and Helianthus tuberosus derived introduction to Alternaria helianthi. Helia, v.18, n.23, p.67-72, 1995.

REDDY, P.C.; GUPTA, B.M. Disease loss appraisal due to leaf blight of sunflower indicated by Alternaria helianthi. Indian Phytopathology, v.30, p.569-570, 1977.

REDDY, P.C.; GUPTA, B.M. Physiological studies of Alternaria helianthi (Hansf.) Tubaki and Nishihara the incitant of leaf blight of sunflower (Helianthus annuus L). Journal of Turkish Phytopathology, v.10, n.1, p.25-35, 1981.

RIBEIRO, I.J.O.; PARADELA FILHO, O.; SOAVE, J.; CORVELLINI, G.S. Ocorrência de Alternaria helianthi (Hansf.) Tubaki \& Nishihara sobre girassol. Bragantia, v.33, p.81-85, 1974. 
ROTEM, J. The genus Alternaria: biology, epidemiology and pathogenicity. St. Paul: APS Press, 1994.326p.

SAHU, B.K.; GHEMAWAT, M.S.; AGRAWAT, J.M. Susceptibility of sunflower plants to Alternaria helianthi as influenced by plant age. Zeitschrift für Pflanzenkrankheiten und Pflanzenschutz, v.98, p.103-106, 1991.

SALAM, M.A. Resistance in sunflower genotypes to rust and leaf spot. Madras Agricultural Journal, v.81, p.43-44, 1994.

SCHNEITER, A.A. Non-destructive leaf area estimation in sunflower. Agronomy Journal, v.70, p.141-142, 1978.

SCHNEITER, A.A.; MILLER, J.F. Description of sunflower growth stages. Crop Science, v.21, p.901-903, 1981.

SENTELHAS, P.C.; PEZZOPANE, J.R.M.; UNGARO, M.R.G.; MORAES, S.A.; DUDIENAS, C. Aspectos climáticos relacionados à ocorrência da mancha de alternaria em cultivares de girassol. Fitopatologia Brasileira, v.21, p.464-469, 1996.

SIRRY, A.R.; ZAYED, M.A.; SATOUR, M.M.; EL-WAKIL, A.A. Studies on leaf spot of sunflower in Egypt. Agricultural Research Review, v.56, n.2, p.95-104, 1978.

SOMASUNDARA, S.; ANILKUMAR, T.B. Factors affecting infection by Alternaria helianthi and disease development in sunflower. International Journal of Tropical Plant Diseases, v.8, p.241-249, 1990.

SOTO, L.; GONZÁLEZ-ÁVILA, M.; ABREU, S. Dinámica de la alternariosis en el girasol. Ciencias de la Agricultura, v.40, p.22-26, 1990. 
SRINIVAS, T.; CHANDRASEKHARA-RAO, K.; CHATTOPADHYAY, C. Effect of Alternaria blight (Alternaria helianthi; Alternaria alternata) on yield of sunflower (Helianthus annuus L.) in India. Helia, v.21, n.28, p.75-80, 1998.

SRINIVAS, T.; RAO, K.C.S.; CHATTOPADHYAY, C. Physiological studies of Alternaria helianthi (Hansf.) Tubaki and Nishihara, the agent of blight of sunflower. Helia, v.20, n.27, p.51-56, 1997.

SUJATHA, M.; PRABAKARAN, A.J.; CHATTOPADHYAY, C. Reaction of wild sunflowers and certain interspecific hybrids to Alternaria helianthi. Helia, v.20, n.27, p.15-24, 1997.

TENG, P.S. Validation of computer models of plant disease epidemics: a review of philosophy and methodology. Zeitschrift für Pflanzenkrankheiten und Pflanzenschutz, v.88, p.455-459, 1981.

TUITE, J. Plant pathological methods, fungi and bacteria. Minneapolis: Burgess Publications Corporation, 1969. 239p.

VANNOZZI, G.P.; BALDINI, M.; GOMEZ-SANCHEZ, D. Agronomic traits useful in sunflower breeding for drought resistance. Helia, v.22, n.30, p.97-124, 1999.

VELAZHAHAN, R.; NARAYANASAMY, P.; JEYARAJAN, R. Evaluation of sunflower germplasm for field resistance to Alternaria helianthi. Madras Agricultural Journal, v.78, p.143-144, 1991.

VIEIRA, O.V. Validação e difusão de tecnologias para a produção de girassol no Brasil. In: HOFFMANN-CAMPO, C.B.; SARAIVA, O.F. (Org.) Resultados de pesquisa da Embrapa Soja - 2000: girassol e trigo. Londrina: Embrapa Soja, 2001. p.27-29. (Documentos, 165). 
WAGGONER, P.R.; BERGER, R.D. Defoliation, disease and growth. Phytopathology, v.77, n.3, p.393-398, 1987.

WATSON, D. J. Comparative physiological studies on the growth of field crops. I. Variation in net assimilation rate and leaf area between species and varieties, and within and between years. Annals of Botany, v.11, p.41-76, 1947.

WELLES, J.M. 3. Some indirect methods of estimating canopy structure. Remote Sensing Reviews, v.5, n.1, p.31-43, 1990.

WELLES, J.M.; NORMAN, J.M. Instrument for indirect measurement of canopy architecture. Agronomy Journal, v.83, n.5., p.818-825, 1991.

YORINORI, J.T.; HENNING, A.A.; FERREIRA, L.P.; HOMECHIN, M. Diseases of sunflower in Brazil. In: INTERNATIONAL SUNFLOWER CONFERENCE, 11., Mar del Plata, 1985. Proceedings. Toowoonba: International Sunflower Association, 1985. v.2, p.459.

ZIMMER, D.E.; HOES, J.A. Diseases. In: CARTER, J.F. (Ed.) Sunflower science and technology. Madison: American Society of Agronomy, 1978. p.225-262. 
APÊNDICES 

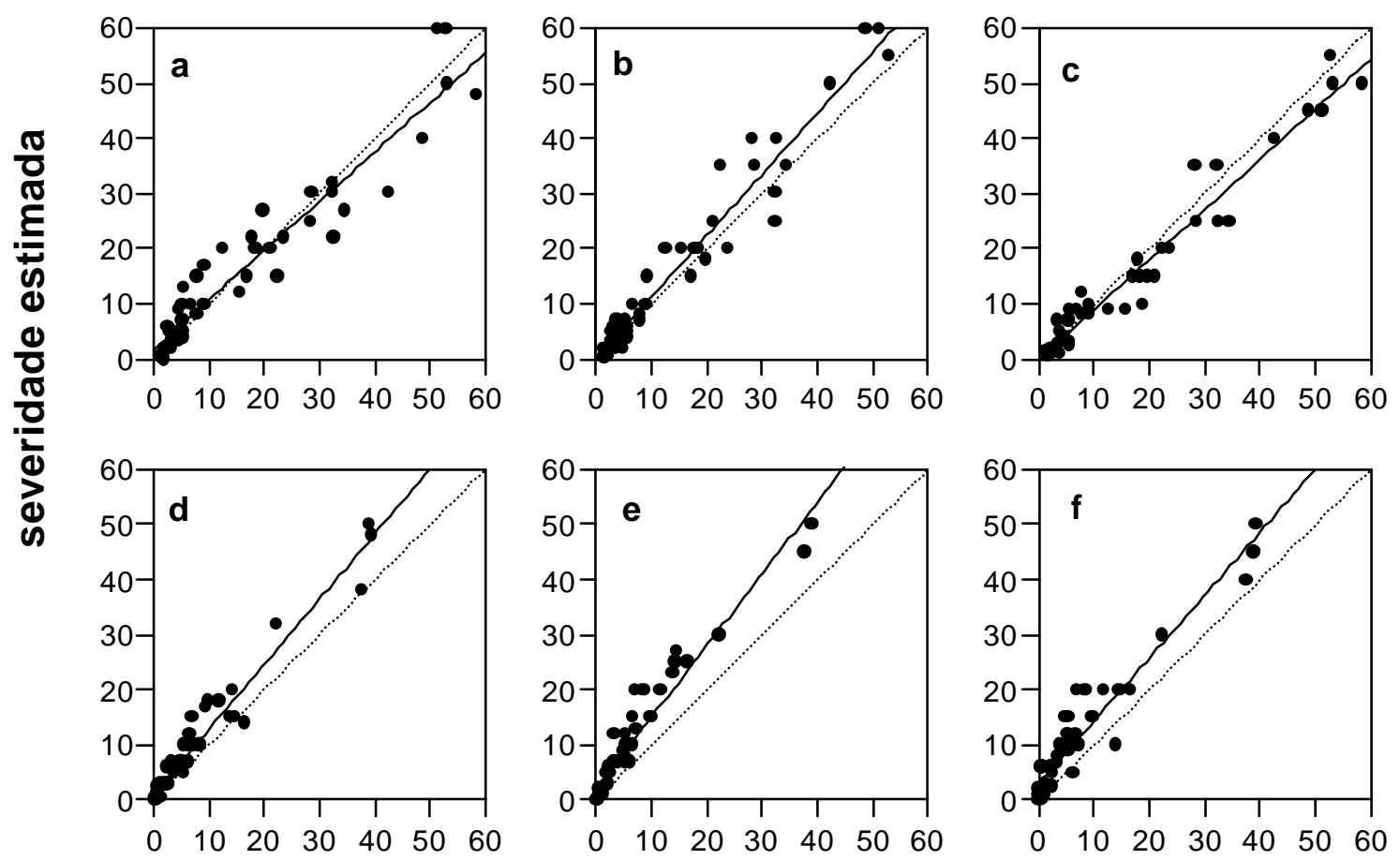

severidade real

Apêndice 1 - Regressões lineares (linha contínua) entre severidades real e estimada, para os avaliadores 1 (a, d), 2 (b, e) e 3 (c, f), quando foram utilizadas folhas desenhadas $(a, b, c)$ ou folhas verdes com sintomas (d, e, f). Pontos representam 50 estimativas de cada avaliador. A linha tracejada representa a situação ideal em que a severidade estimada é idêntica à real. 

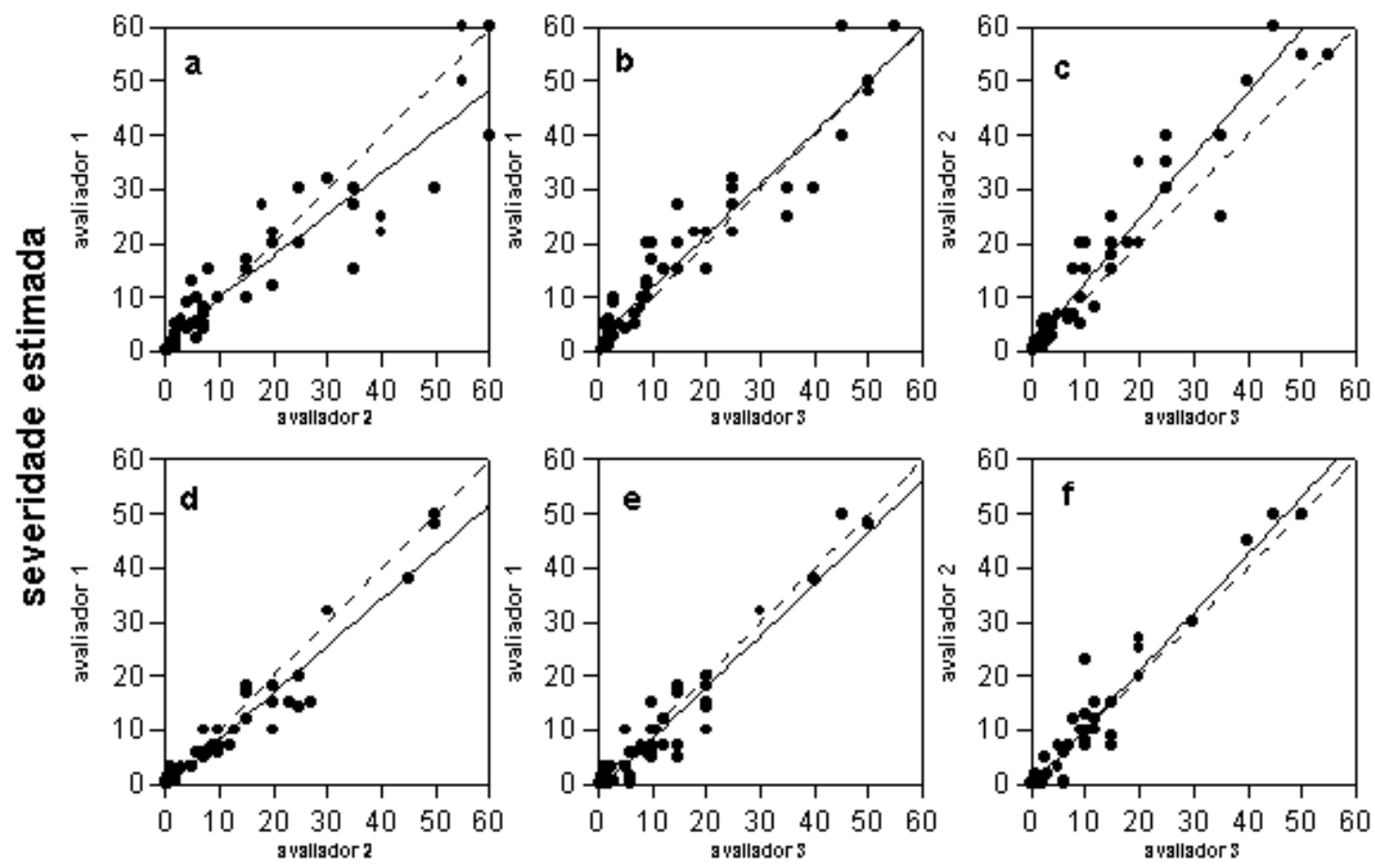

severidade estimada

Apêndice 2 - Regressões lineares (linha contínua) entre severidades estimadas dos diferentes avaliadores: 1 × 2 (a, d), 1 × 3 (b, e) e 2 × 3 (c, f), quando foram utilizadas folhas desenhadas $(a, b, c)$ ou folhas verdes com sintomas (d, e, f). Pontos representam 50 estimativas de cada avaliador. A linha tracejada representa a situação ideal em que a severidade estimada é idêntica à real. 

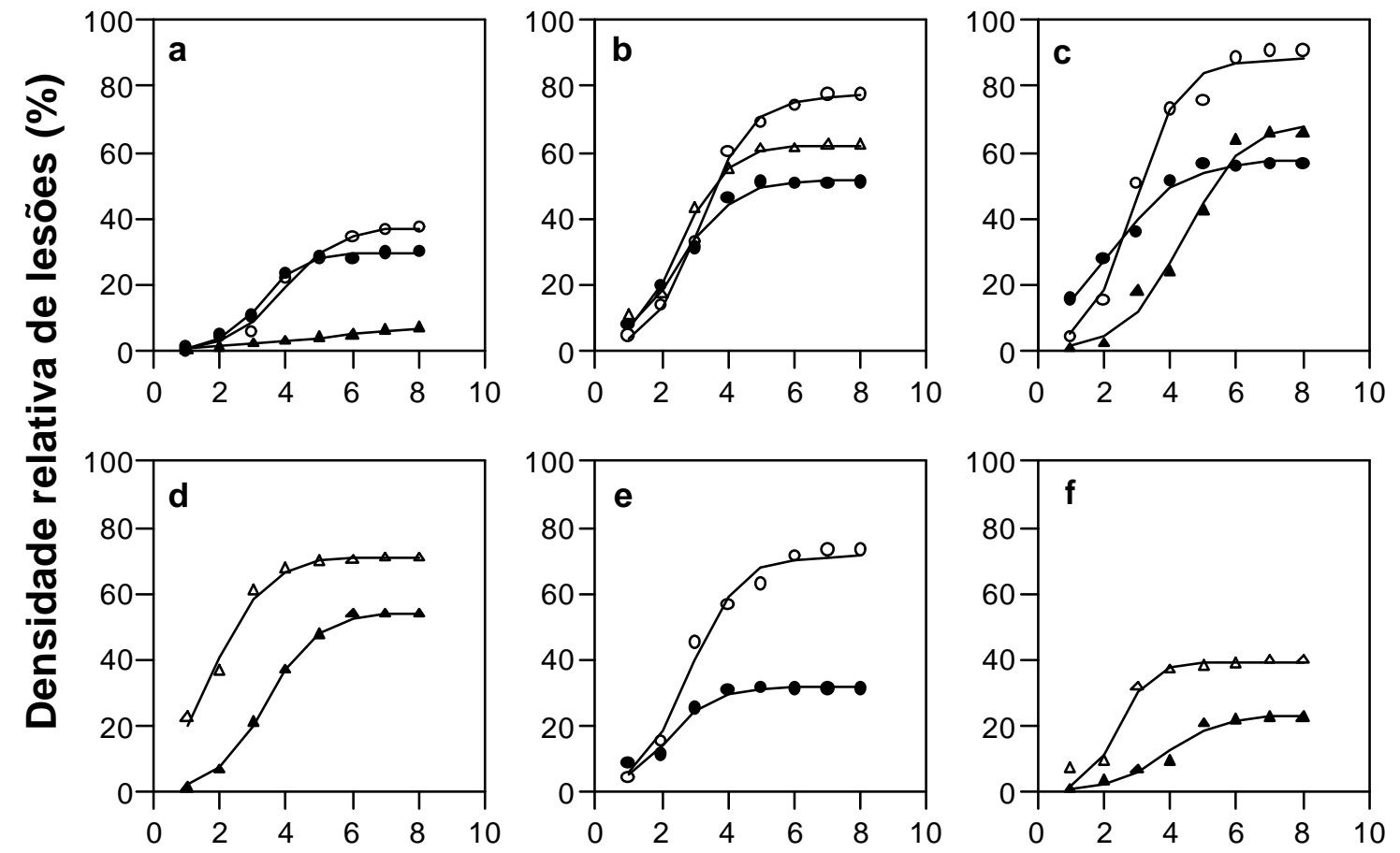

Dias após inoculação

Apêndice 3 - Densidade relativa de lesões de $A$. helianthi em girassol, para as temperaturas de $15{ }^{\circ} \mathrm{C}$ (a), $20{ }^{\circ} \mathrm{C}$ (b), $25{ }^{\circ} \mathrm{C}$ (c), $27,5{ }^{\circ} \mathrm{C}$ (d), $30{ }^{\circ} \mathrm{C}$ (e) e $32,5^{\circ} \mathrm{C}$ (f), nos ensaios 1 (círculo cheio), 2 (círculo vazio), 3 (triângulo cheio) e 4 (triângulo vazio). Linhas correspondem à função logística ajustada aos dados. 
Apêndice 4 - Coeficientes de determinação $\left(R^{2}\right)$ e parâmetros da função logística, $Y=B_{1} /\left(1+B_{2} \exp \left(-B_{3} X\right)\right)$, onde $Y$ é a densidade relativa de lesões, $X$ é dias após inoculação, $B_{1}$ é a estimativa da assíntota máxima, $B_{2}$ é o parâmetro relacionado ao inóculo inicial e $B_{3}$ é a taxa de progresso da doença, ajustada para as diferentes temperaturas.

\begin{tabular}{ccrcc}
\hline Temperatura $\left({ }^{\mathbf{0}} \mathbf{C}\right)$ & $\boldsymbol{B}_{\mathbf{1}}$ & \multicolumn{1}{c}{$\boldsymbol{B}_{\mathbf{2}}$} & $\boldsymbol{B}_{\mathbf{3}}$ & $\boldsymbol{R}^{\mathbf{2}}$ \\
\hline Ensaio 1 & & & & \\
15 & 29,76 & 172,02 & 1,57 & 0,99 \\
20 & 51,73 & 18,52 & 1,18 & 0,99 \\
25 & 57,74 & 7,27 & 0,93 & 0,99 \\
30 & 32,02 & 17,21 & 1,33 & 0,98
\end{tabular}

Ensaio 2

$\begin{array}{rrrrr}15 & 37,34 & 146,68 & 1,27 & 0,99 \\ 20 & 77,12 & 70,16 & 1,34 & 0,99 \\ 25 & 88,10 & 68,91 & 1,45 & 0,99 \\ 30 & 71,53 & 40,26 & 1,32 & 0,99\end{array}$

Ensaio 3

$\begin{array}{crrrr}15 & 8,28 & 18,08 & 0,56 & 0,98 \\ 25 & 69,48 & 123,62 & 1,09 & 0,99 \\ 27,5 & 54,32 & 87,69 & 1,32 & 0,99 \\ 32,5 & 23,57 & 93,13 & 1,16 & 0,98\end{array}$

Ensaio 4

\begin{tabular}{crrrr}
20 & 62,19 & 31,96 & 1,38 & 0,99 \\
27,5 & 71,20 & 8,36 & 1,21 & 0,99 \\
32,5 & 39,29 & 139,47 & 2,04 & 0,98 \\
\hline
\end{tabular}



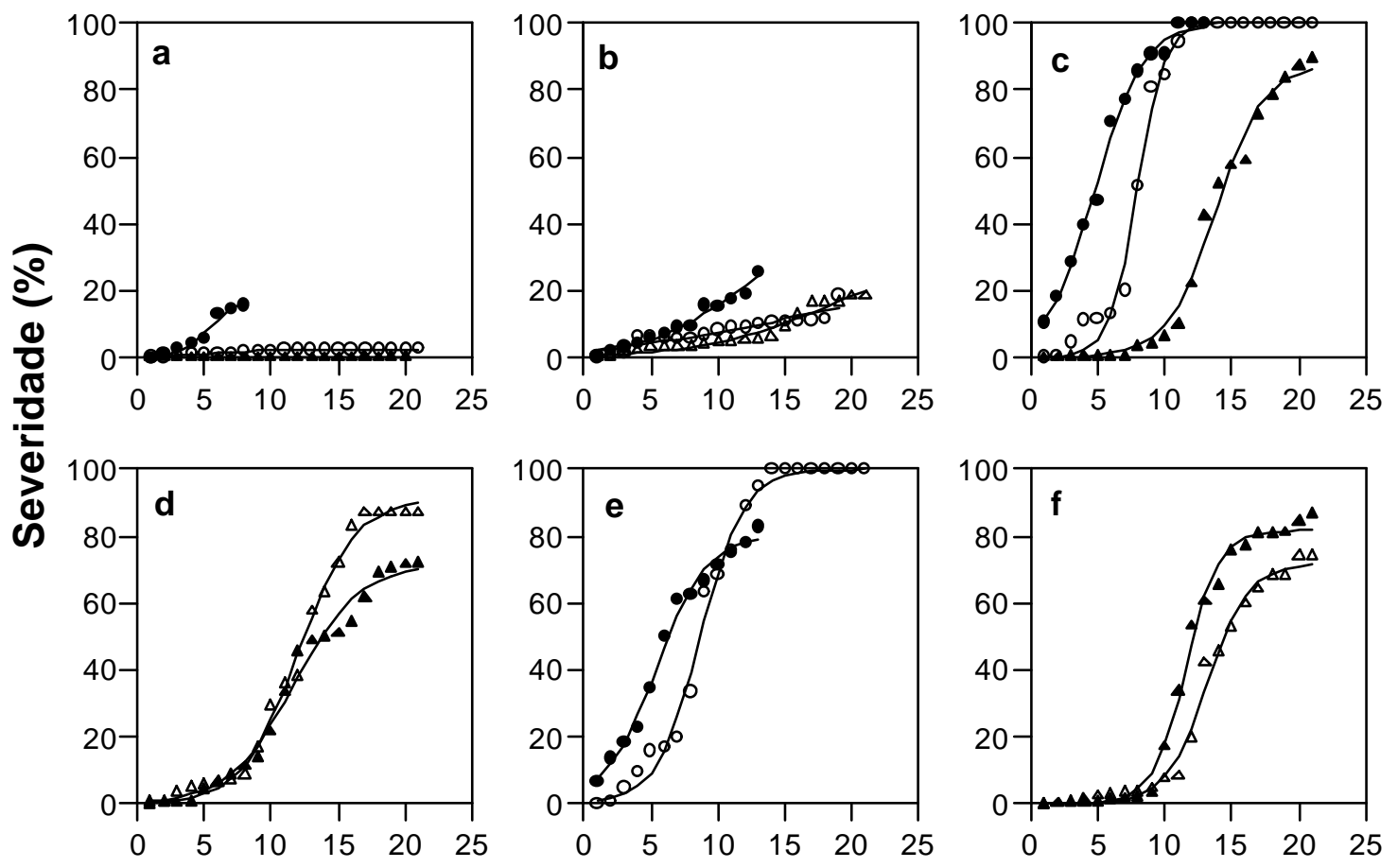

Dias após inoculação

Apêndice 5 - Severidade de A. helianthi em girassol, para as temperaturas de $15^{\circ} \mathrm{C}$ (a), $20{ }^{\circ} \mathrm{C}(\mathrm{b}), 25{ }^{\circ} \mathrm{C}(\mathrm{c}), 27,5^{\circ} \mathrm{C}(\mathrm{d}), 30^{\circ} \mathrm{C}$ (e) e $32,5^{\circ} \mathrm{C}$ (f), nos ensaios 1 (círculo cheio), 2 (círculo vazio), 3 (triângulo cheio) e 4 (triângulo vazio). Linhas correspondem à função logística ajustada aos dados. 
Apêndice 6 - Coeficientes de determinação $\left(R^{2}\right)$ e parâmetros da função logística, $Y=B_{1} /\left(1+B_{2} \exp \left(-B_{3} X\right)\right)$, onde $Y$ é a severidade, $X$ é dias após inoculação, $B_{1}$ é a estimativa da assíntota máxima, $B_{2}$ é o parâmetro relacionado ao inóculo inicial e $B_{3}$ é a taxa de progresso da doença, ajustada para as diferentes temperaturas.

\begin{tabular}{crrrr}
\hline Temperatura $\left({ }^{\mathbf{C}} \mathbf{C}\right)$ & $\boldsymbol{B}_{\mathbf{1}}$ & $\boldsymbol{B}_{\mathbf{2}}$ & $\boldsymbol{B}_{\mathbf{3}}$ & $\boldsymbol{R}^{\mathbf{2}}$ \\
\hline Ensaio 1 & & & & \\
15 & 17,77 & 131,66 & 0,91 & 0,98 \\
20 & 40,38 & 26,66 & 0,28 & 0,98 \\
25 & 100,00 & 14,17 & 0,55 & 0,99 \\
30 & 80,47 & 16,28 & 0,52 & 0,99
\end{tabular}

Ensaio 2

$\begin{array}{rrrrr}15 & 2,64 & 12,50 & 0,43 & 0,98 \\ 20 & 21,22 & 8,20 & 0,15 & 0,91 \\ 25 & 100,00 & 2810,86 & 1,00 & 0,99 \\ 30 & 100,00 & 210,52 & 0,61 & 0,99\end{array}$

Ensaio 3

$\begin{array}{crrll}15 & 0,08 & 38,51 & 0,42 & 0,99 \\ 25 & 87,88 & 1945,43 & 0,55 & 0,99 \\ 27,5 & 71,70 & 122,62 & 0,41 & 0,99 \\ 32,5 & 81,71 & 10656,56 & 0,80 & 0,99\end{array}$

Ensaio 4

\begin{tabular}{crrrr}
20 & 30,55 & 51,57 & 0,22 & 0,97 \\
27,5 & 91,11 & 295,79 & 0,47 & 0,99 \\
32,5 & 72,05 & 4777,35 & 0,64 & 0,99 \\
\hline
\end{tabular}



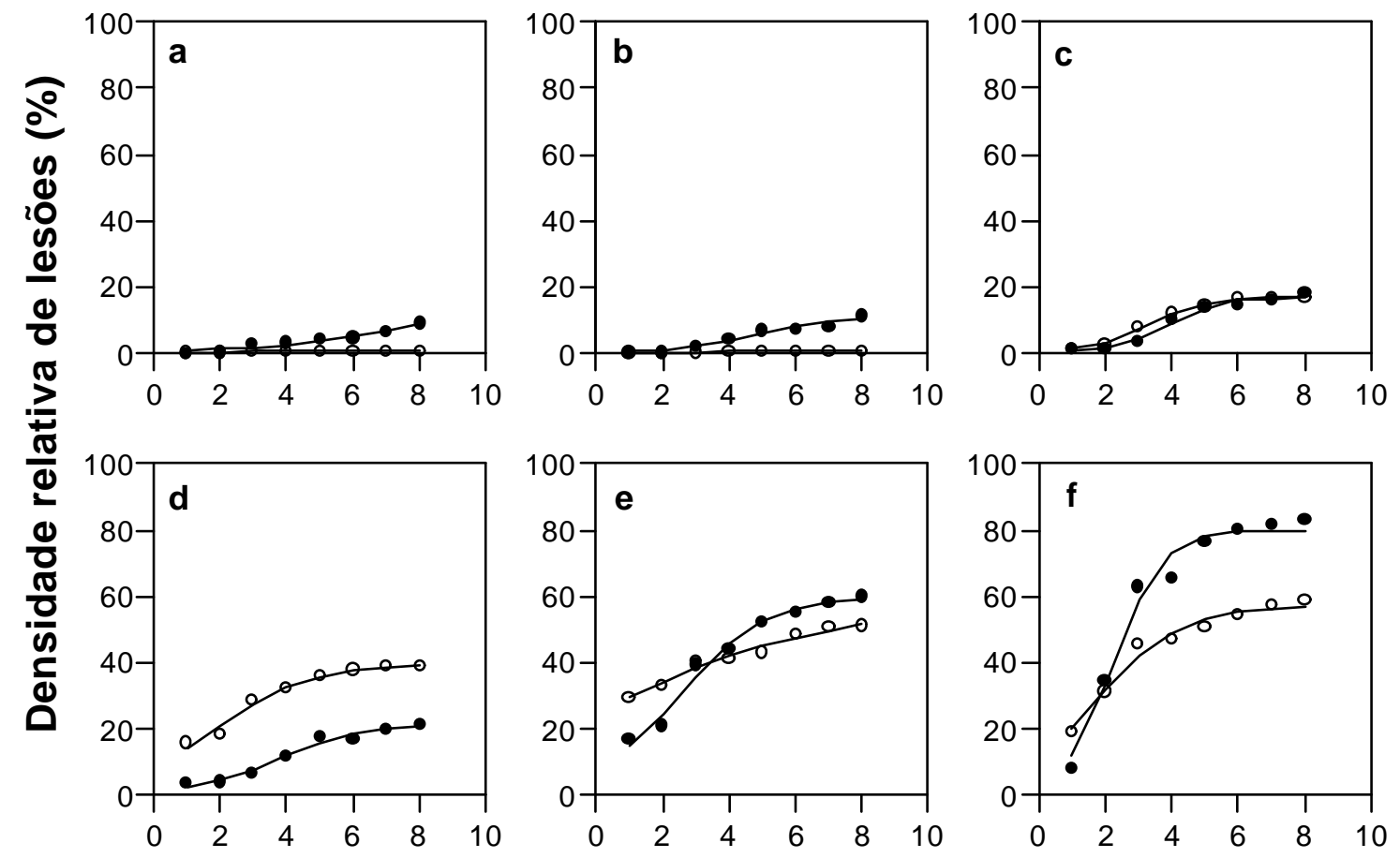

Dias após inoculação

Apêndice 7 - Densidade relativa de lesões de A. helianthi em girassol, para a duração do período de molhamento foliar de $2 \mathrm{~h}$ (a), $4 \mathrm{~h} \mathrm{(b),} 8 \mathrm{~h}$ (c), $12 \mathrm{~h} \mathrm{(d),} 16 \mathrm{~h}$ (e) e 24 h (f), nos ensaios 1 (círculo cheio) e 2 (círculo vazio). Linhas correspondem à função logística ajustada aos dados. 
Apêndice 8 - Coeficientes de determinação $\left(R^{2}\right)$ e parâmetros da função logística, $Y=B_{1} /\left(1+B_{2} \exp \left(-B_{3} X\right)\right)$, onde $Y$ é a densidade relativa de lesões, $X$ é dias após inoculação, $B_{1}$ é a estimativa da assíntota máxima, $B_{2}$ é o parâmetro relacionado ao inóculo inicial e $B_{3}$ é a taxa de progresso da doença, ajustada para as diferentes durações do período de molhamento foliar.

\begin{tabular}{crrrr}
\hline $\begin{array}{c}\text { Duração do período de } \\
\text { molhamento foliar (h) }\end{array}$ & $\boldsymbol{B}_{\mathbf{1}}$ & $\boldsymbol{B}_{\mathbf{2}}$ & $\boldsymbol{B}_{\mathbf{3}}$ & $\boldsymbol{R}^{\mathbf{2}}$ \\
\hline Ensaio 1 & & & & \\
2 & 22,91 & 37,87 & 0,40 & 0,97 \\
4 & 11,34 & 44,93 & 0,78 & 0,98 \\
8 & 17,10 & 120,78 & 1,23 & 0,99 \\
12 & 21,85 & 18,28 & 0,77 & 0,99 \\
16 & 60,35 & 6,37 & 0,74 & 0,99 \\
24 & 79,80 & 23,14 & 1,40 & 0,99 \\
Ensaio 2 & & & & \\
2 & 0,83 & 13,81 & 1,25 & 0,96 \\
4 & 0,68 & $6,14 \mathrm{e}+8$ & 6,88 & 1,00 \\
8 & 16,72 & 43,15 & 1,18 & 0,99 \\
12 & 40,06 & 3,42 & 0,67 & 0,99 \\
16 & 56,59 & 1,23 & 0,31 & 0,99 \\
24 & 57,18 & 4,01 & 0,80 & 0,99 \\
\hline
\end{tabular}



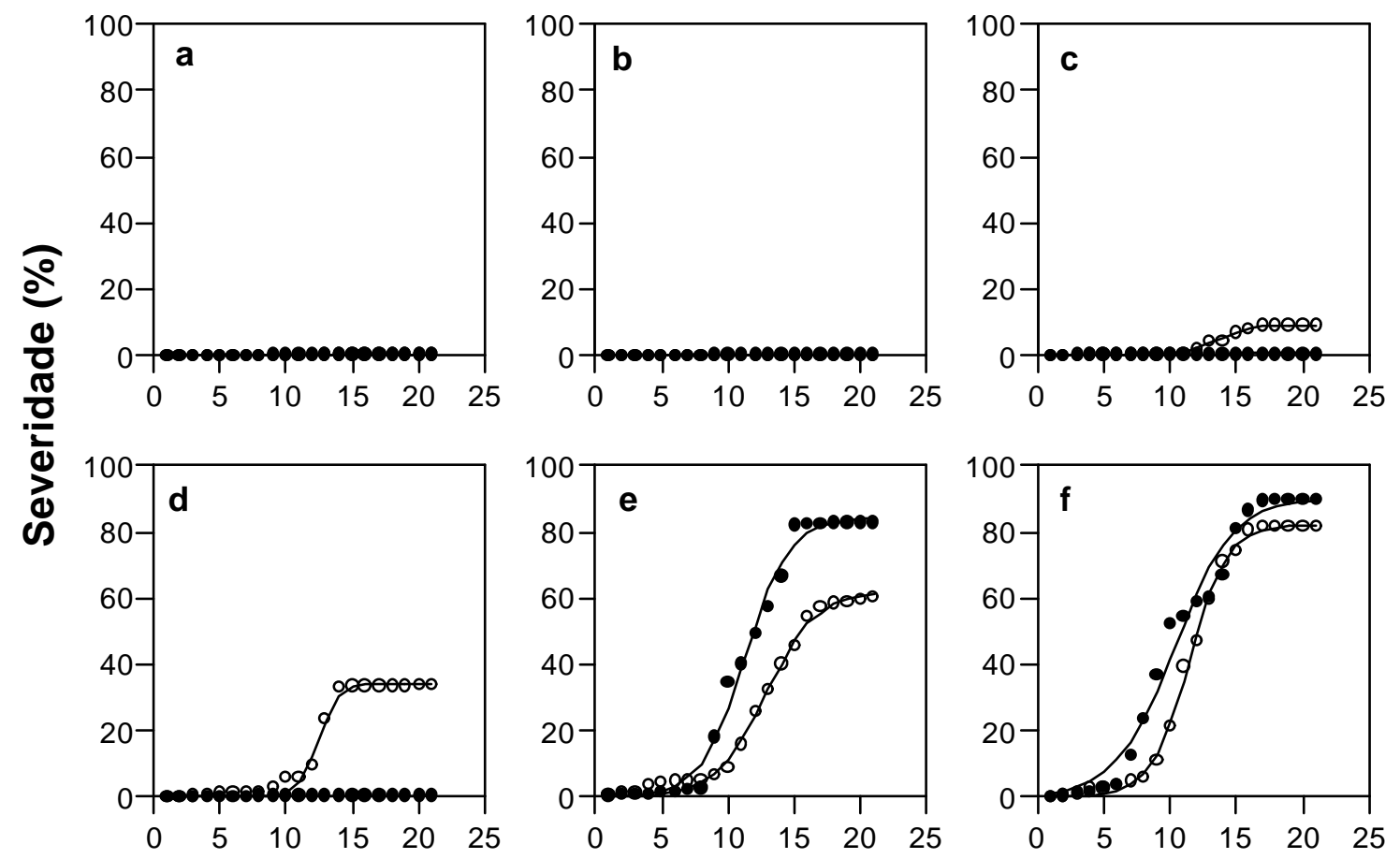

Dias após inoculação

Apêndice 9 - Severidade de A. helianthi em girassol, para a duração do período de molhamento foliar de $2 \mathrm{~h}$ (a), $4 \mathrm{~h}$ (b), 8 h (c), $12 \mathrm{~h}$ (d), $16 \mathrm{~h}$ (e) e $24 \mathrm{~h}$ (f), nos ensaios 1 (círculo cheio) e 2 (círculo vazio). Linhas correspondem à função logística ajustada aos dados. 
Apêndice 10 - Coeficientes de determinação $\left(R^{2}\right)$ e parâmetros da função logística, $Y=B_{1} /\left(1+B_{2} \exp \left(-B_{3} X\right)\right)$, onde $Y$ é a severidade, $X$ é dias após inoculação, $B_{1}$ é a estimativa da assíntota máxima, $B_{2}$ é o parâmetro relacionado ao inóculo inicial e $B_{3}$ é a taxa de progresso da doença, ajustada para as diferentes durações do período de molhamento foliar.

\begin{tabular}{crrrr}
\hline $\begin{array}{c}\text { Duração do período de } \\
\text { molhamento foliar (h) }\end{array}$ & \multicolumn{1}{l}{$\boldsymbol{B}_{\mathbf{1}}$} & \multicolumn{1}{c}{$\boldsymbol{B}_{\mathbf{2}}$} & $\boldsymbol{B}_{\mathbf{3}}$ & $\boldsymbol{R}^{\mathbf{2}}$ \\
\hline Ensaio 1 & 0,10 & $1,16 \mathrm{e}+10$ & 2,81 & 0,98 \\
2 & 0,37 & 3044,81 & 0,61 & 0,97 \\
4 & 0,45 & 607,19 & 0,78 & 0,98 \\
8 & 0,66 & 17,30 & 0,30 & 0,98 \\
12 & 84,35 & 957,78 & 0,61 & 0,99 \\
16 & 90,34 & 109,58 & 0,45 & 0,99 \\
24 & & & & \\
Ensaio 2 & 0,06 & 6,43 & 0,25 & 0,95 \\
2 & 0,04 & 116,70 & 0,44 & 0,96 \\
4 & 9,23 & 41553,76 & 0,78 & 0,99 \\
8 & 34,15 & $1,62 \mathrm{e}+7$ & 1,34 & 0,99 \\
12 & 61,90 & 871,76 & 0,53 & 0,99 \\
16 & 82,32 & 2521,97 & 0,68 & 0,99 \\
24 & & & &
\end{tabular}



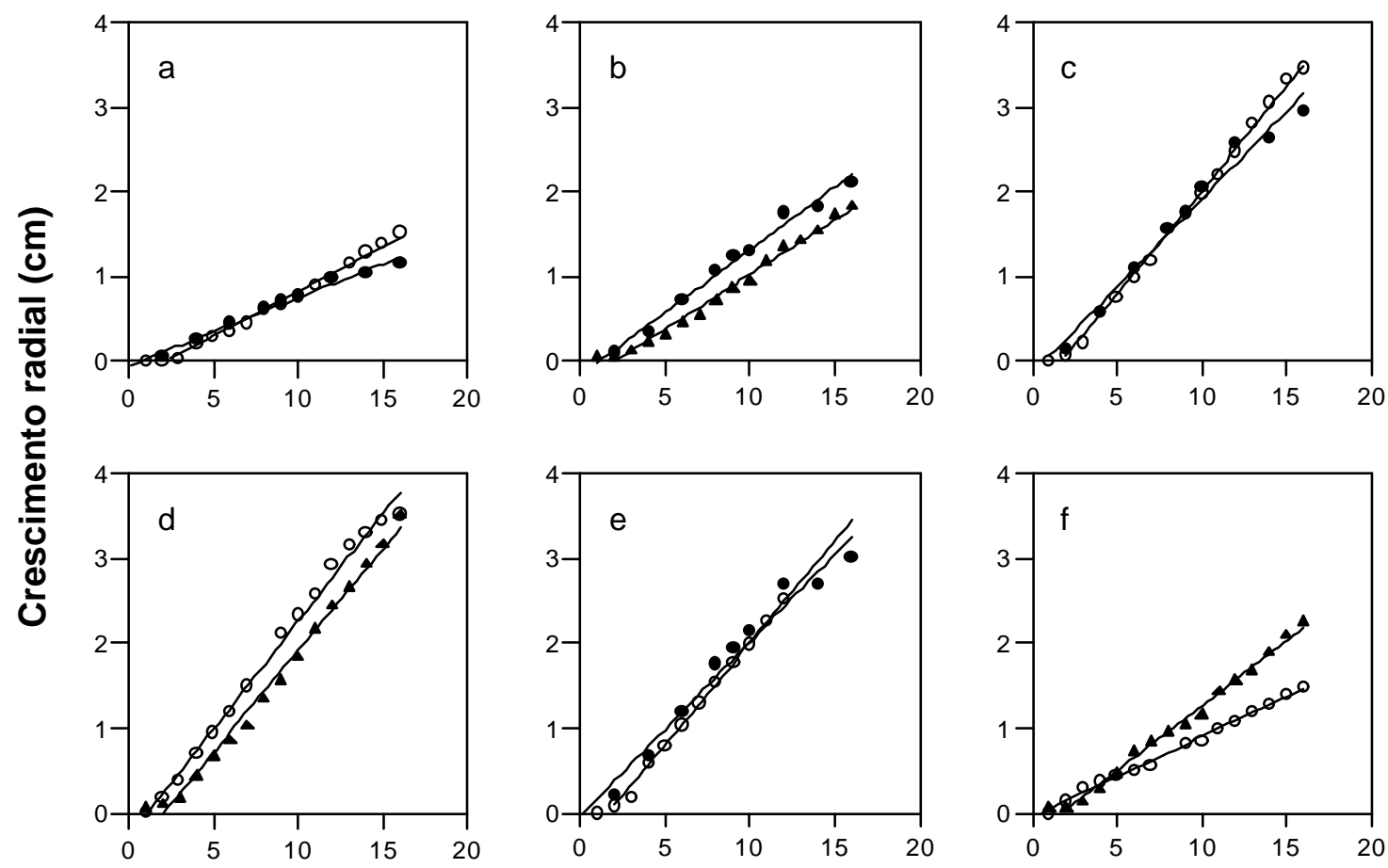

Tempo (dias)

Apêndice 11 - Crescimento micelial de A. helianthi em girassol, para as temperaturas de $15{ }^{\circ} \mathrm{C}(\mathrm{a}), 20{ }^{\circ} \mathrm{C}(\mathrm{b}), 25{ }^{\circ} \mathrm{C}$ (c), $27,5{ }^{\circ} \mathrm{C}(\mathrm{d}), 30{ }^{\circ} \mathrm{C}$ (e) e $32,5{ }^{\circ} \mathrm{C}$ (f), nos ensaios 1 (círculo cheio), 2 (círculo vazio) e 3 (triângulo cheio). Linhas correspondem à função linear ajustada aos dados. 
Apêndice 12 - Coeficientes de determinação $\left(R^{2}\right)$ e parâmetros da função linear, $Y=a+$ $b X$, onde $Y$ é o crescimento micelial (cm), $X$ é tempo (dias), $a$ é a interseção e $b$ é o coeficiente angular, ajustada para as diferentes temperaturas.

\begin{tabular}{cccc}
\hline Temperatura $\left({ }^{\mathbf{0}} \mathbf{C}\right)$ & $\boldsymbol{a}$ & $\boldsymbol{b}$ & $\boldsymbol{R}^{\mathbf{2}}$ \\
\hline Ensaio 1 & & & \\
15 & $-0,05$ & 0,08 & 0,98 \\
20 & $-0,16$ & 0,14 & 0,98 \\
25 & $-0,15$ & 0,20 & 0,97 \\
30 & $-0,04$ & 0,20 & 0,96
\end{tabular}

Ensaio 2

$\begin{array}{cccc}15 & -0,24 & 0,10 & 0,98 \\ 25 & -0,43 & 0,24 & 0,99 \\ 27,5 & -0,28 & 0,25 & 0,99 \\ 32,5 & -0,05 & 0,09 & 0,99 \\ 30 & -0,38 & 0,23 & 0,99\end{array}$

Ensaio 3

\begin{tabular}{cccc}
20 & $-0,26$ & 0,12 & 0,98 \\
27,5 & $-0,49$ & 0,24 & 0,98 \\
32,5 & $-0,26$ & 0,15 & 0,99 \\
\hline
\end{tabular}



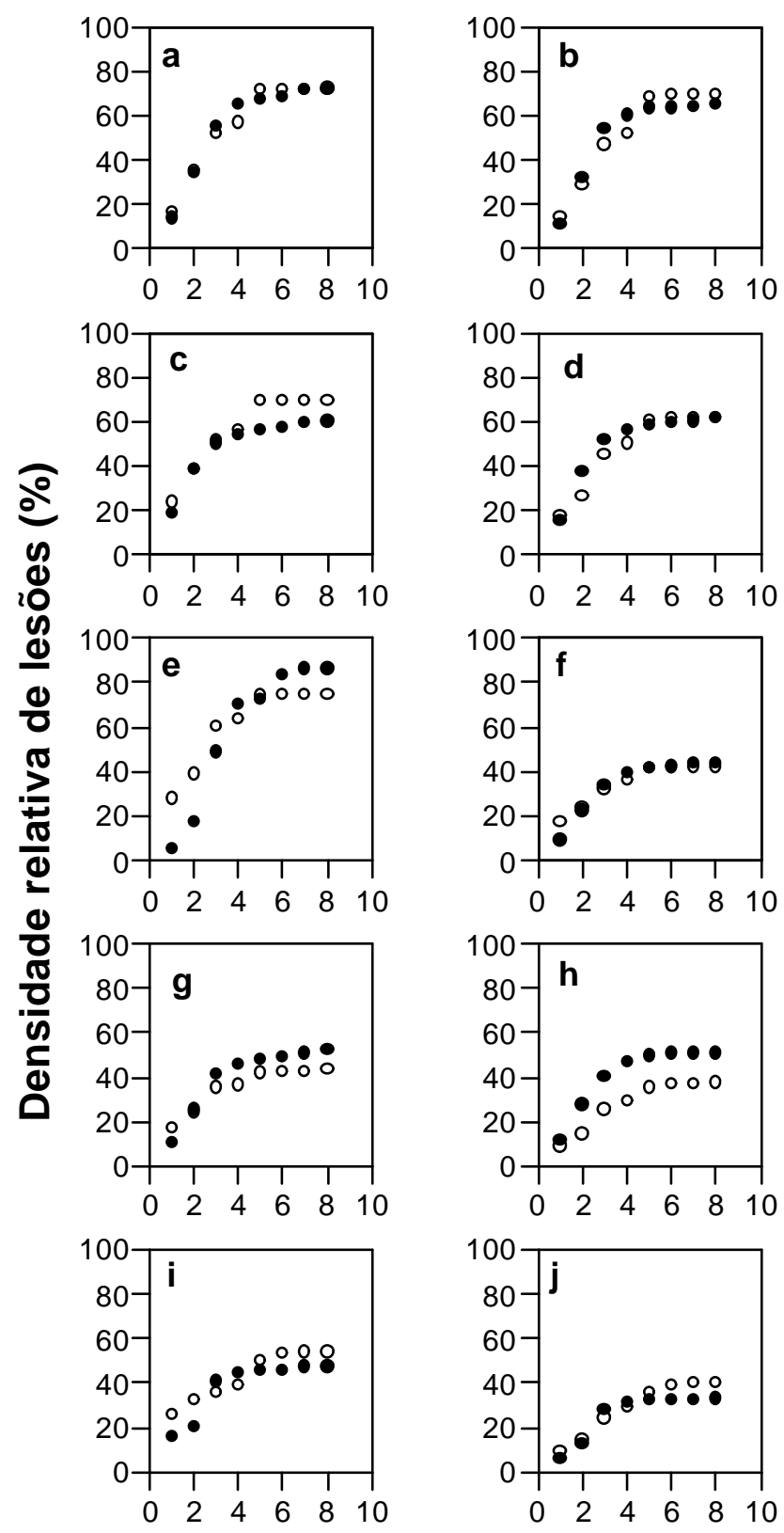

\section{Dias após inoculação}

Apêndice 13 - Densidade relativa de lesões de A. helianthi em 10 híbridos de girassol: Agrobel 910 (a), Agrobel 920 (b), Agrobel 960 (c), BRS 191 (d), SE02 (e), HT1 (f), HT9 (g), HT14 (h), M734 (i) e M742 (j), nos ensaios 1 (círculo cheio) e 2 (círculo vazio). Pontos correspondem à média de 10 folhas. 

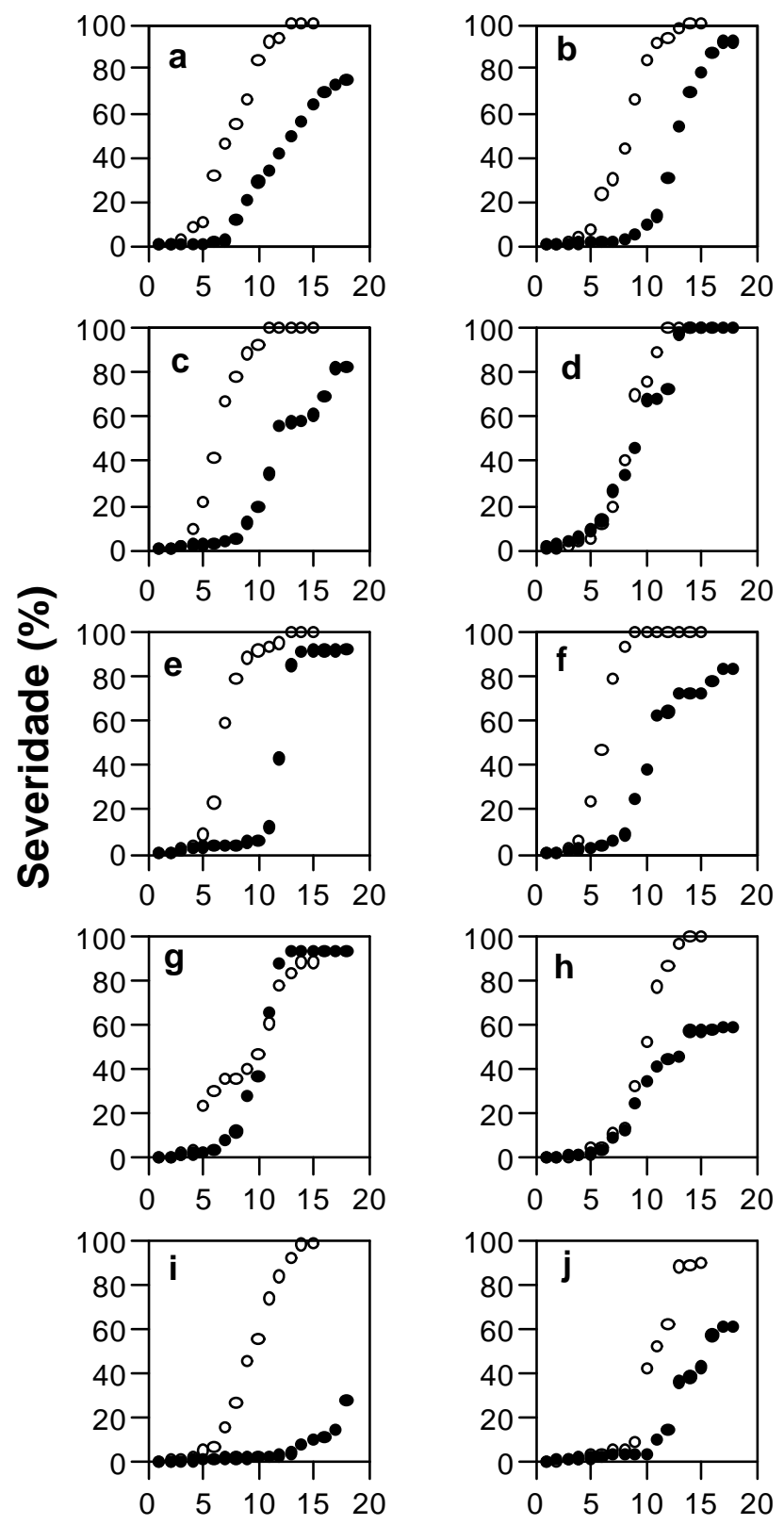

\section{Dias após inoculação}

Apêndice 14 - Severidade de A. helianthi em 10 híbridos de girassol: Agrobel 910 (a), Agrobel 920 (b), Agrobel 960 (c), BRS 191 (d), SE02 (e), HT1 (f), HT9 (g), HT14 (h), M734 (i) e M742 (j), nos ensaios 1 (círculo cheio) e 2 (círculo vazio). Pontos correspondem à média de 10 folhas. 

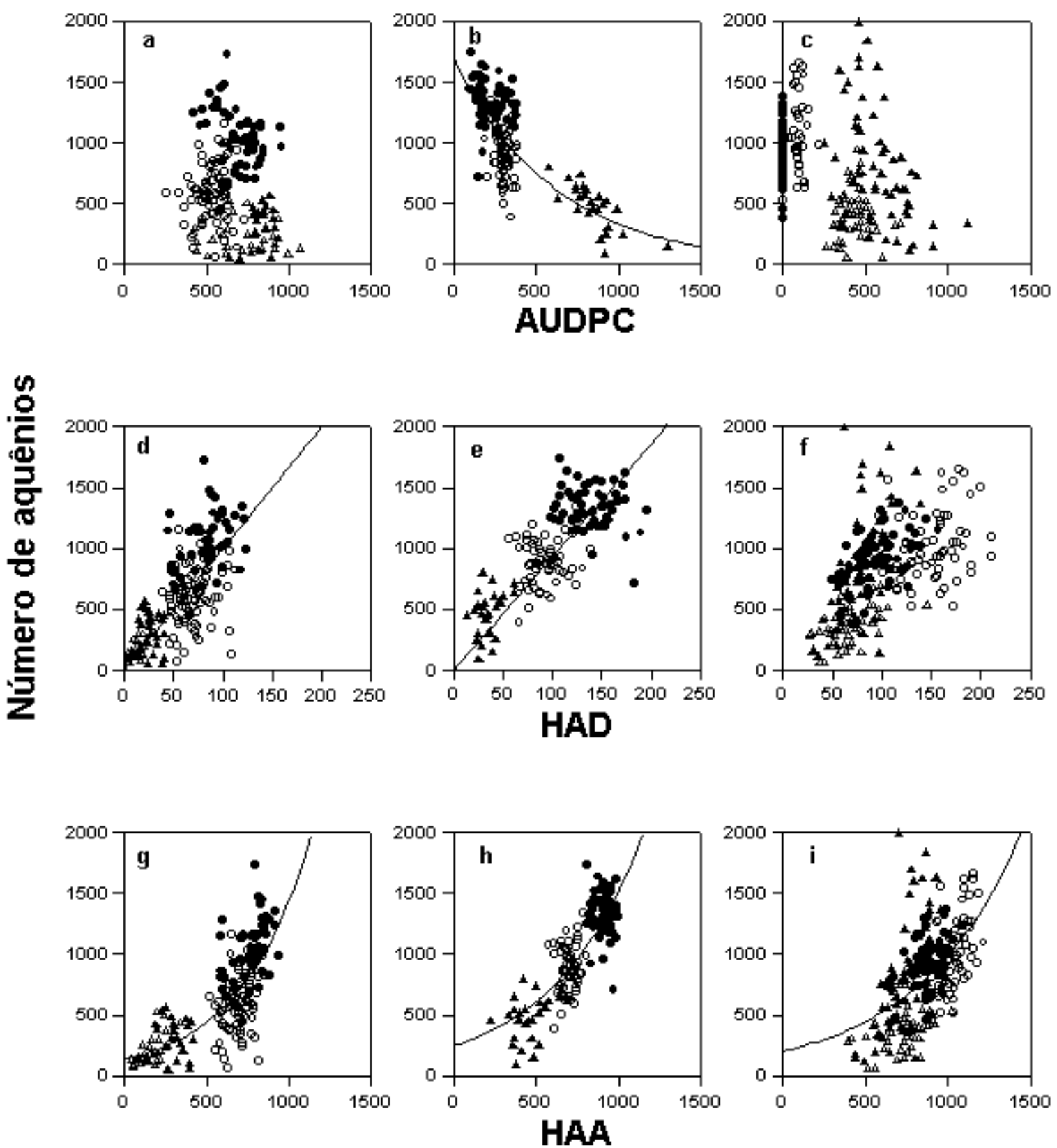

Apêndice 15 - AUDPC, HAD (em dias) ou HAA ( $\left.\mathrm{MJ} \mathrm{m}^{-2}\right)$ versus número de aquênios, para mancha de Alternaria em girassol, semeado em quatro épocas (outubro - círculo cheio, novembro - círculo vazio, dezembro - triângulo cheio, janeiro - triângulo vazio), em três safras consecutivas (1997/1998 - a, d, g; 1998/1999 - b, e, h; 1999/2000 - c, f, i). Linhas representam ajuste dos modelos exponencial negativo (b), linear (d, e) e exponencial (g, h, i). 

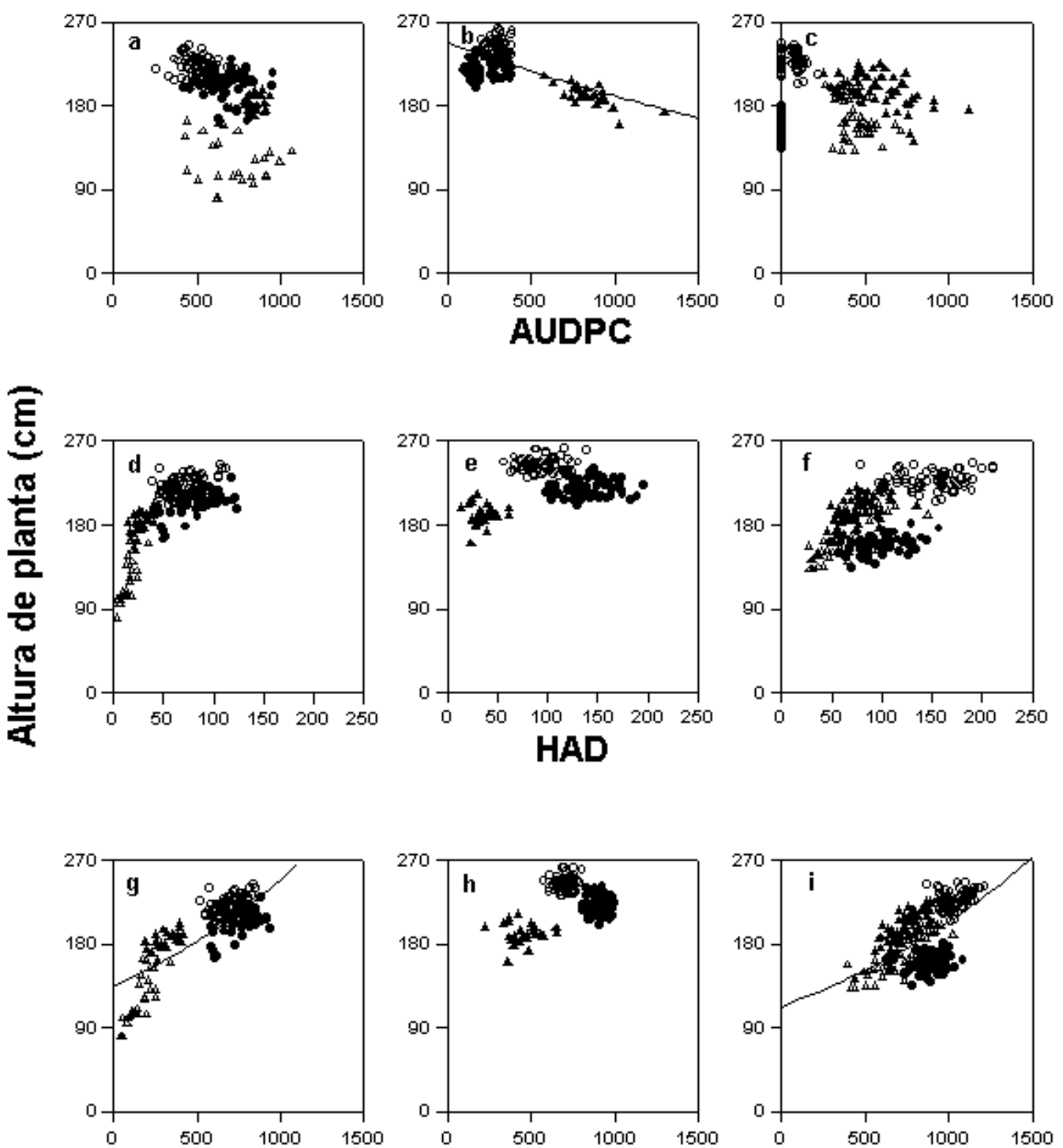

HAA

Apêndice 16 - AUDPC, HAD (em dias) ou HAA $\left(\mathrm{MJ} \mathrm{m}^{-2}\right)$ versus altura de planta $(\mathrm{cm})$, para mancha de Alternaria em girassol, semeado em quatro épocas (outubro - círculo cheio, novembro - círculo vazio, dezembro - triângulo cheio, janeiro - triângulo vazio), em três safras consecutivas (1997/1998 a, d, g; 1998/1999 - b, e, h; 1999/2000 - c, f, i). Linhas representam ajuste dos modelos exponencial negativo (b) e exponencial (g, i). 

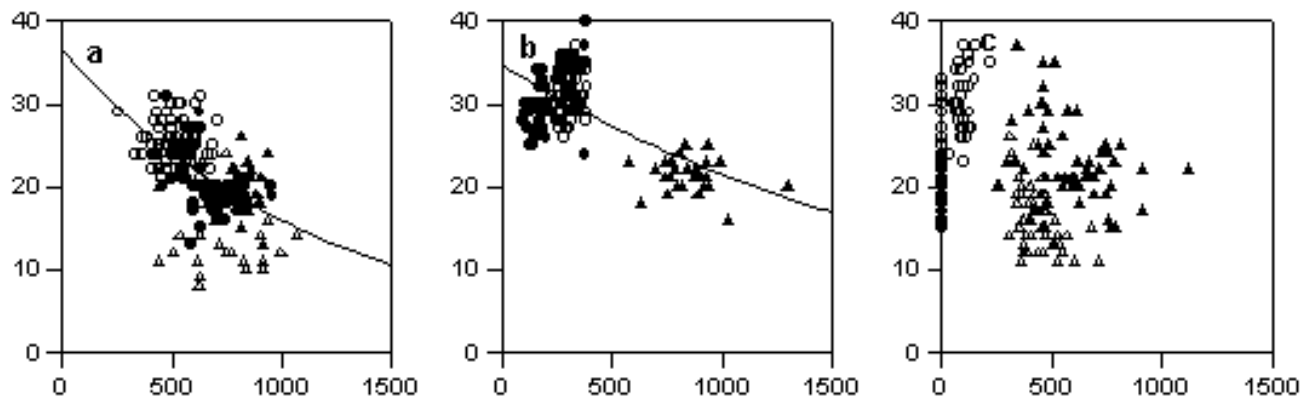

AUDPC
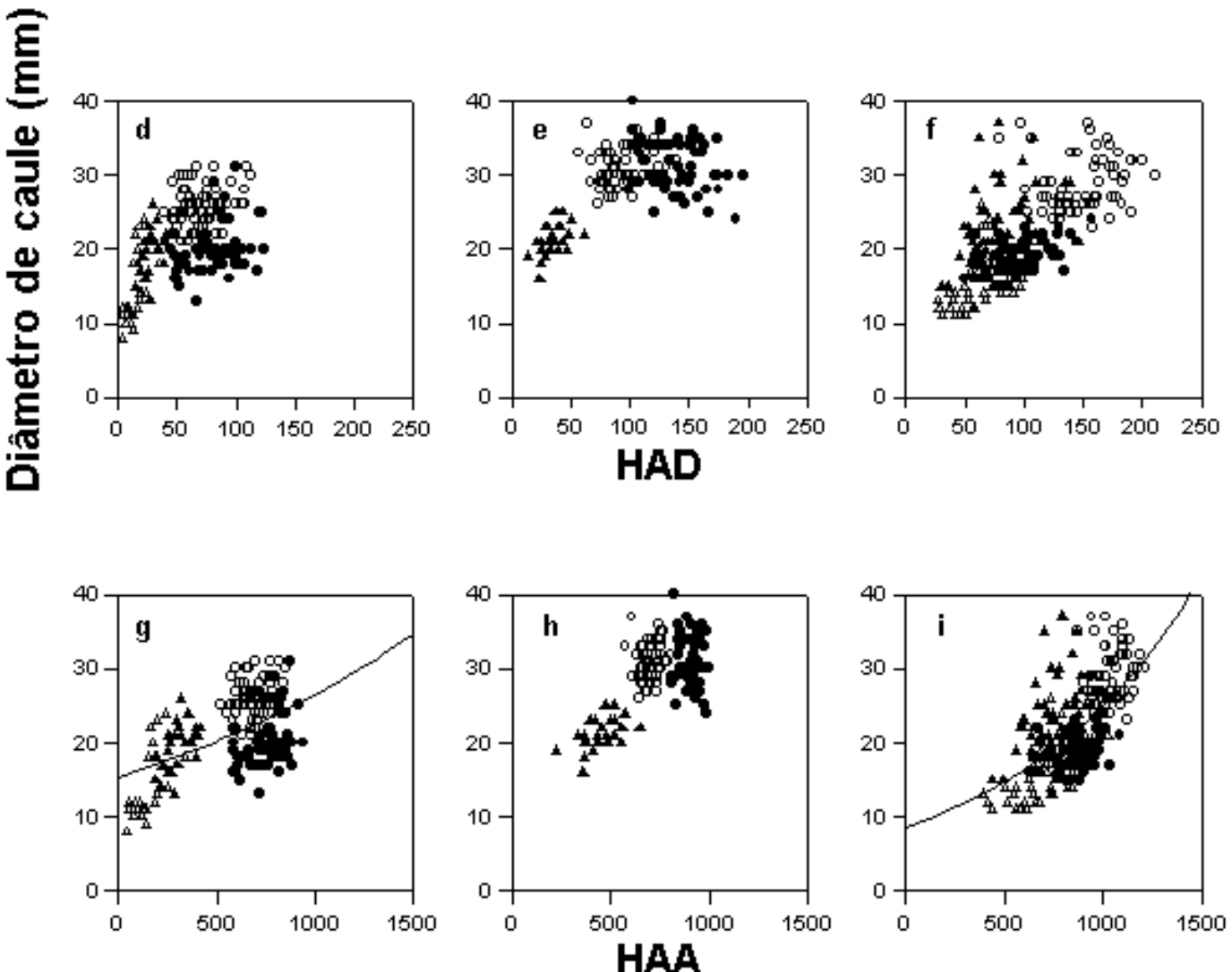

Apêndice 17 - AUDPC, HAD (em dias) ou HAA (MJ m²) versus diâmetro de caule (mm), para mancha de Alternaria em girassol, semeado em quatro épocas (outubro - círculo cheio, novembro - círculo vazio, dezembro - triângulo cheio, janeiro - triângulo vazio), em três safras consecutivas (1997/1998 a, d, g; 1998/1999 - b, e, h; 1999/2000 - c, f, i). Linhas representam ajuste dos modelos exponencial negativo (a, b) e exponencial (g, i). 

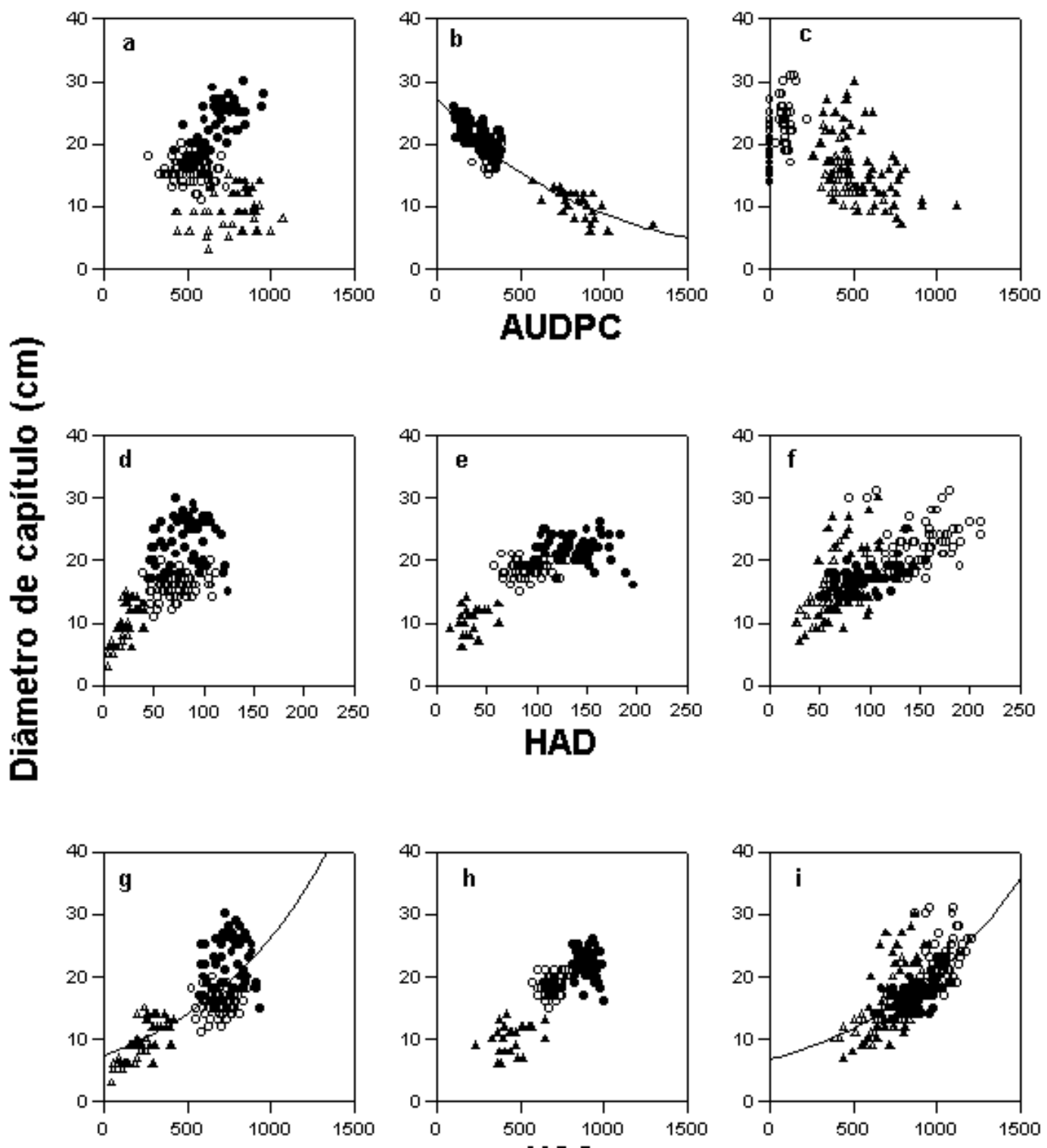

HAA

Apêndice 18 - AUDPC, HAD (em dias) ou HAA $\left(\mathrm{MJ} \mathrm{m}^{-2}\right)$ versus diâmetro de capítulo $(\mathrm{cm})$, para mancha de Alternaria em girassol, semeado em quatro épocas (outubro - círculo cheio, novembro - círculo vazio, dezembro - triângulo cheio, janeiro - triângulo vazio), em três safras consecutivas (1997/1998 a, d, g; 1998/1999 - b, e, h; 1999/2000 - c, f, i). Linhas representam ajuste dos modelos exponencial negativo (b) e exponencial (g, i). 

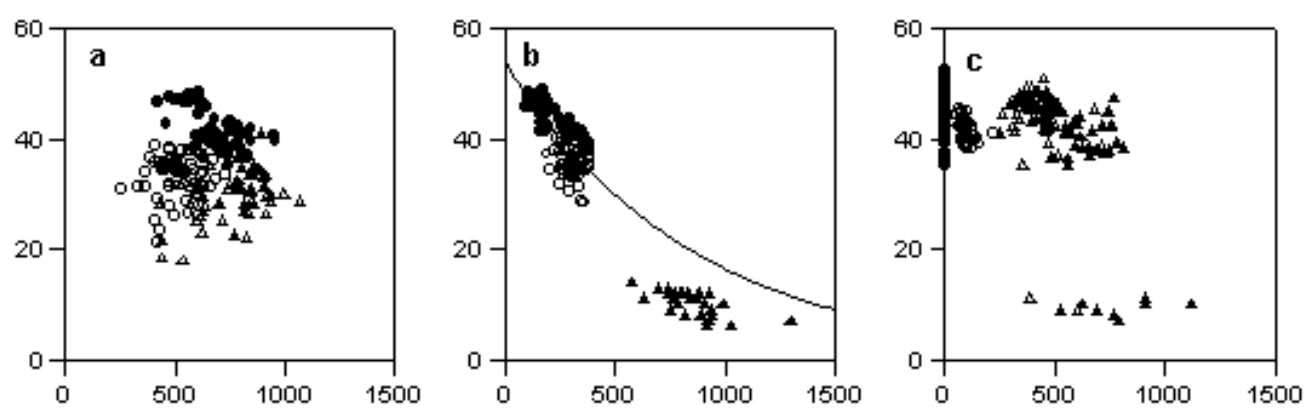

AUDPC
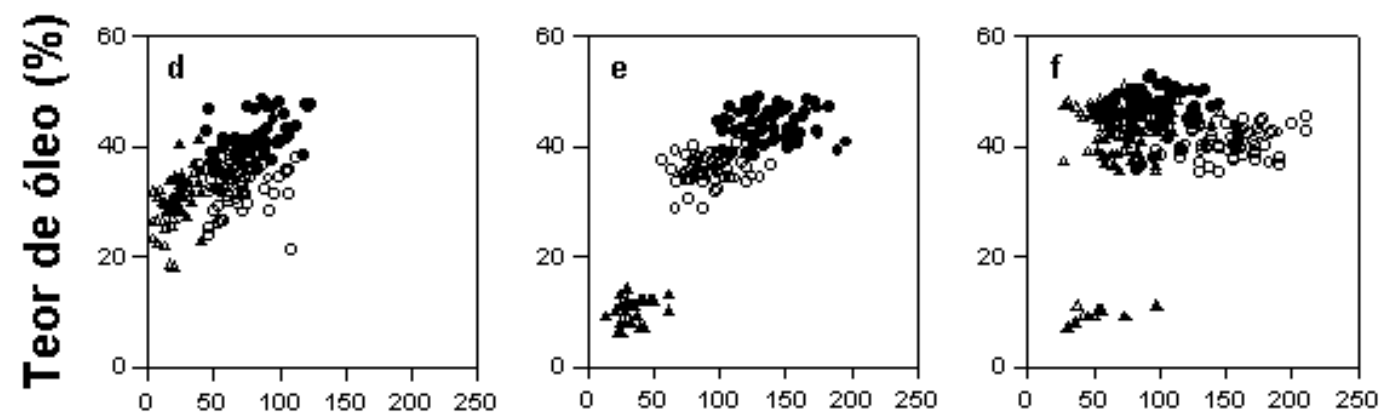

HAD
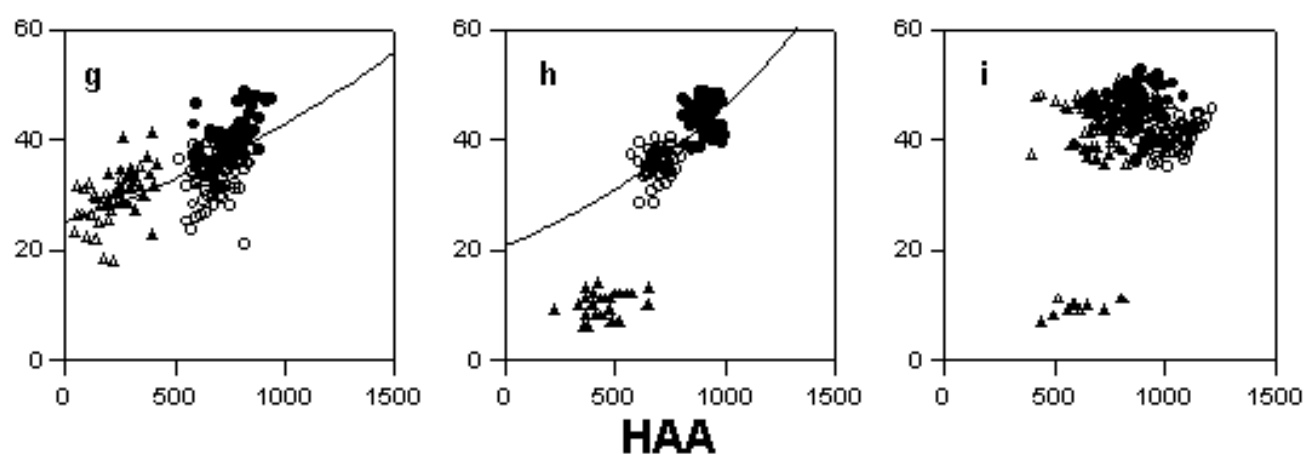

Apêndice 19 - AUDPC, HAD (em dias) ou HAA $\left(\mathrm{MJ} \mathrm{m}^{-2}\right)$ versus teor de óleo (\%), para mancha de Alternaria em girassol, semeado em quatro épocas (outubro círculo cheio, novembro - círculo vazio, dezembro - triângulo cheio, janeiro - triângulo vazio), em três safras consecutivas (1997/1998 - a, d, g; 1998/1999 - b, e, h; 1999/2000 - c, f, i). Linhas representam ajuste dos modelos exponencial negativo (b) e exponencial $(\mathrm{g}, \mathrm{h})$. 

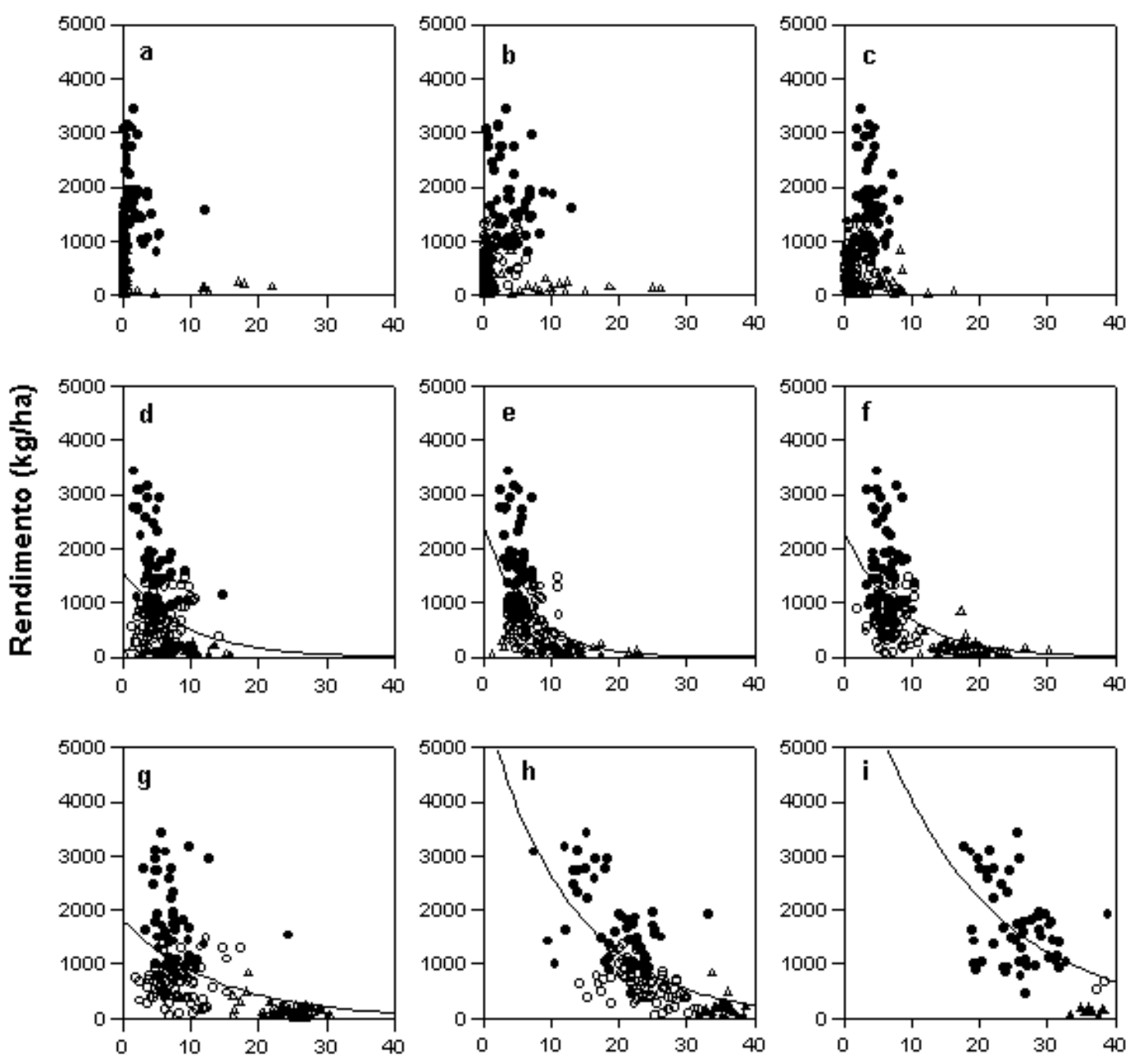

Severidade $(\%)$

Apêndice 20 - Severidade (\%) nas diferentes fases de desenvolvimento (V10 - a, V15 b, V21 - c, R1 - d, R3 - e, R5.5 - f, R6 - g, R7 - h, R8 - i) versus rendimento (kg/ha), para mancha de Alternaria em girassol, semeado em quatro épocas (outubro - círculo cheio, novembro - círculo vazio, dezembro - triângulo cheio, janeiro - triângulo vazio), na safra 1997/1998. Linhas representam ajuste do modelo exponencial negativo. 

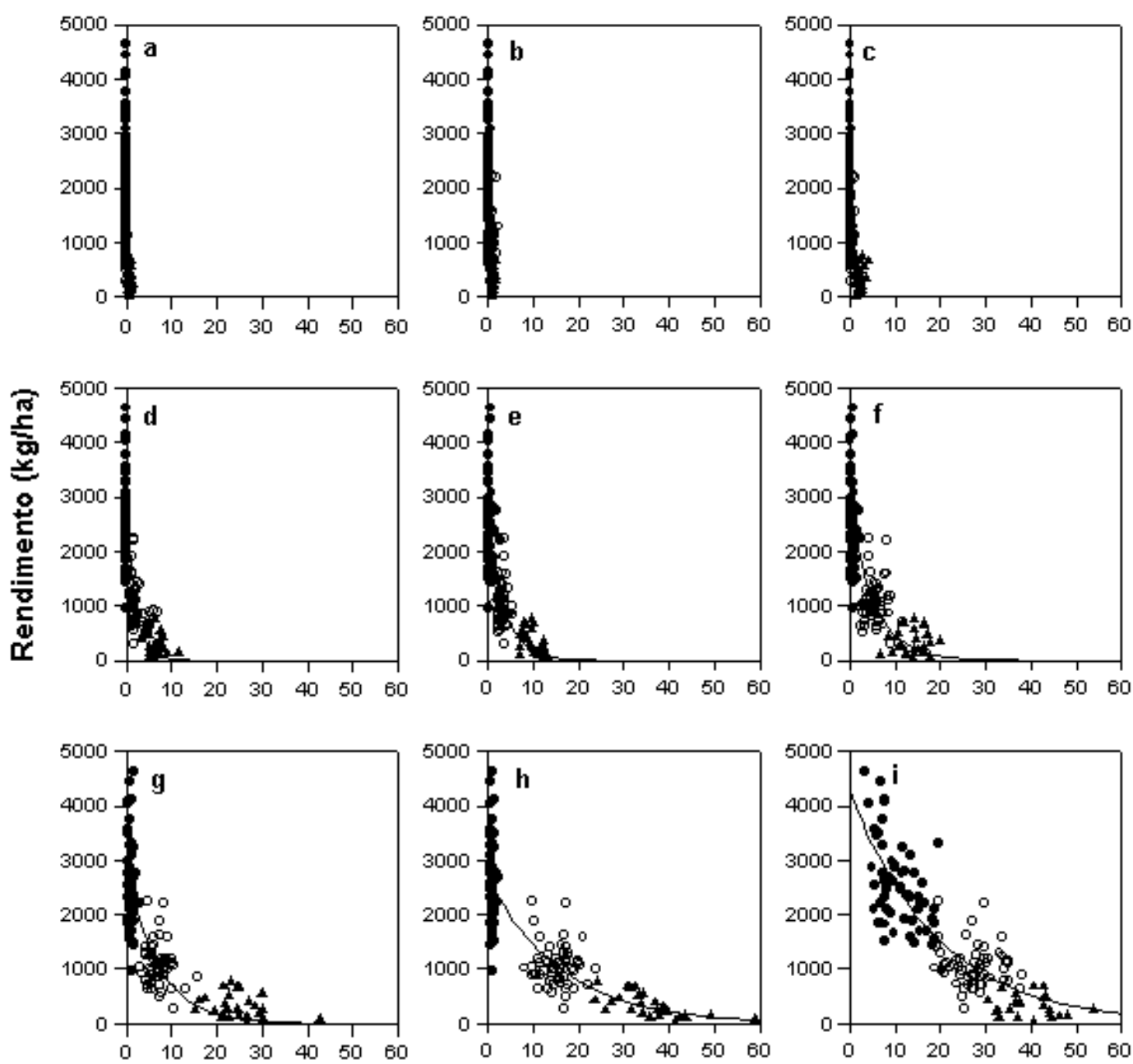

Severidade (\%)

Apêndice 21 - Severidade (\%) nas diferentes fases de desenvolvimento (V4 - a, V10 - b, V18 - c, R1 - d, R2 - e, R3 - f, R5.5 - g, R6 - h, R7 - i) versus rendimento (kg/ha), para mancha de Alternaria em girassol, semeado em quatro épocas (outubro - círculo cheio, novembro - círculo vazio, dezembro triângulo cheio), na safra 1998/1999. Linhas representam ajuste do modelo exponencial negativo. 

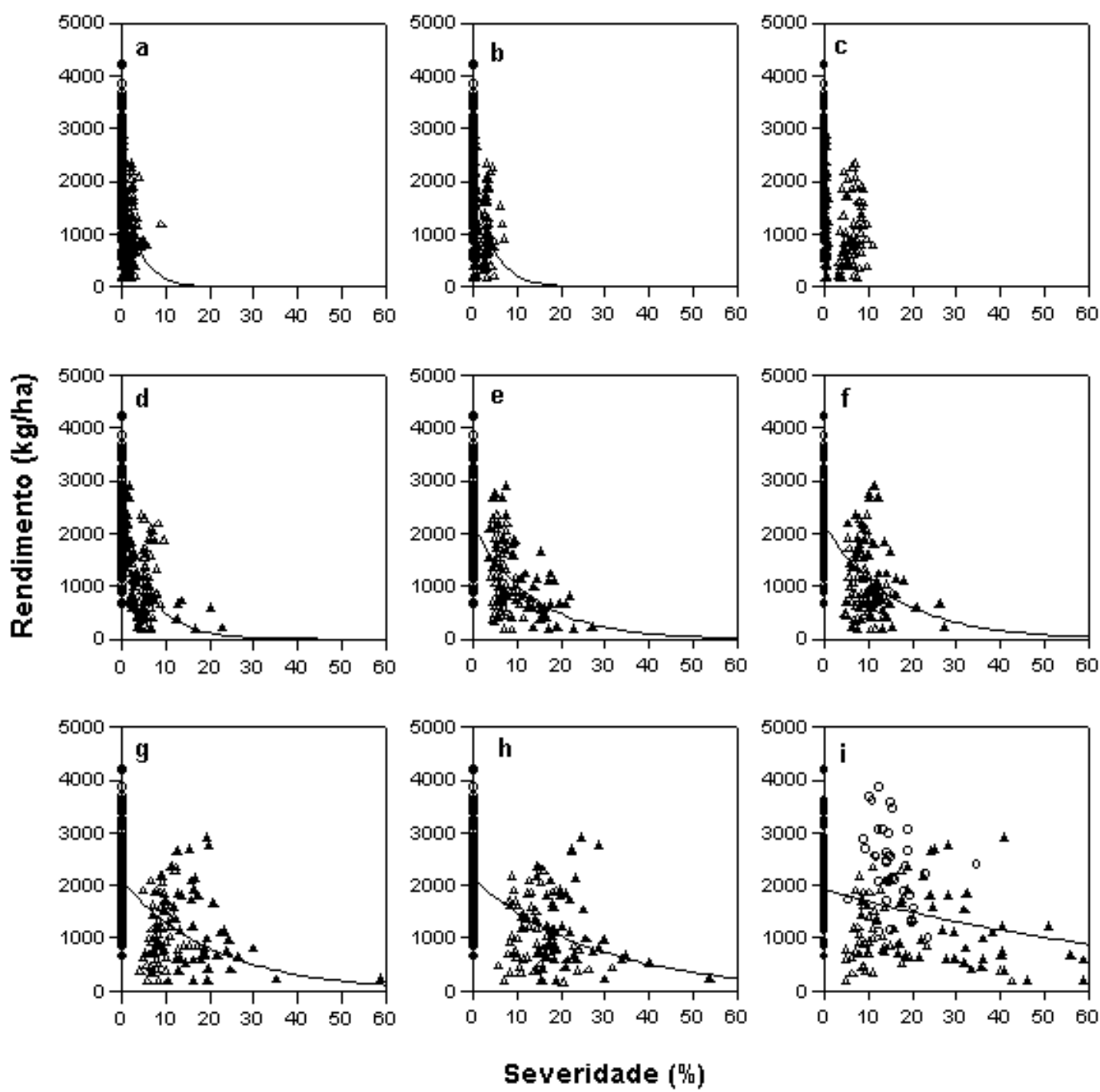

Severidade $(\%)$

Apêndice 22 - Severidade (\%) nas diferentes fases de desenvolvimento (V10 - a, V16 b, R2 - c, R3 - d, R4 - e, R5.9 - f, R6 - g, R7 - h, R8 - i) versus rendimento (kg/ha), para mancha de Alternaria em girassol, semeado em quatro épocas (outubro - círculo cheio, novembro - círculo vazio, dezembro triângulo cheio, janeiro - triângulo vazio), na safra 1999/2000. Linhas representam ajuste do modelo exponencial negativo. 

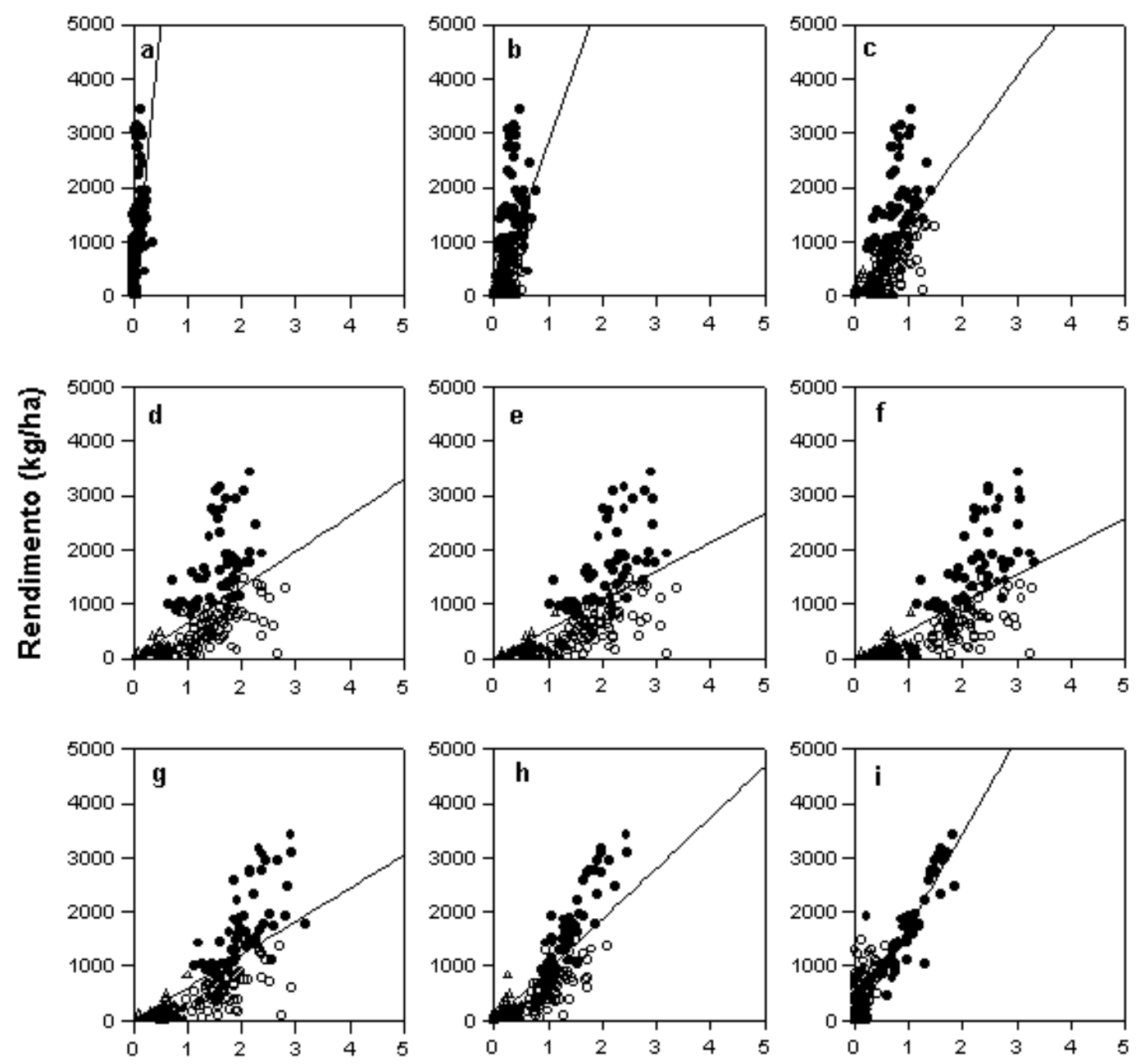

HLAI

Apêndice 23 - HLAI nas diferentes fases de desenvolvimento (V10 - a, V15 - b, V21 - c, R1 - d, R3 - e, R5.5 - f, R6 - g, R7 - h, R8 - i) versus rendimento (kg/ha), para mancha de Alternaria em girassol, semeado em quatro épocas (outubro - círculo cheio, novembro - círculo vazio, dezembro - triângulo cheio, janeiro - triângulo vazio), na safra 1997/1998. Linhas representam ajuste do modelo linear com interseção forçada a zero. 

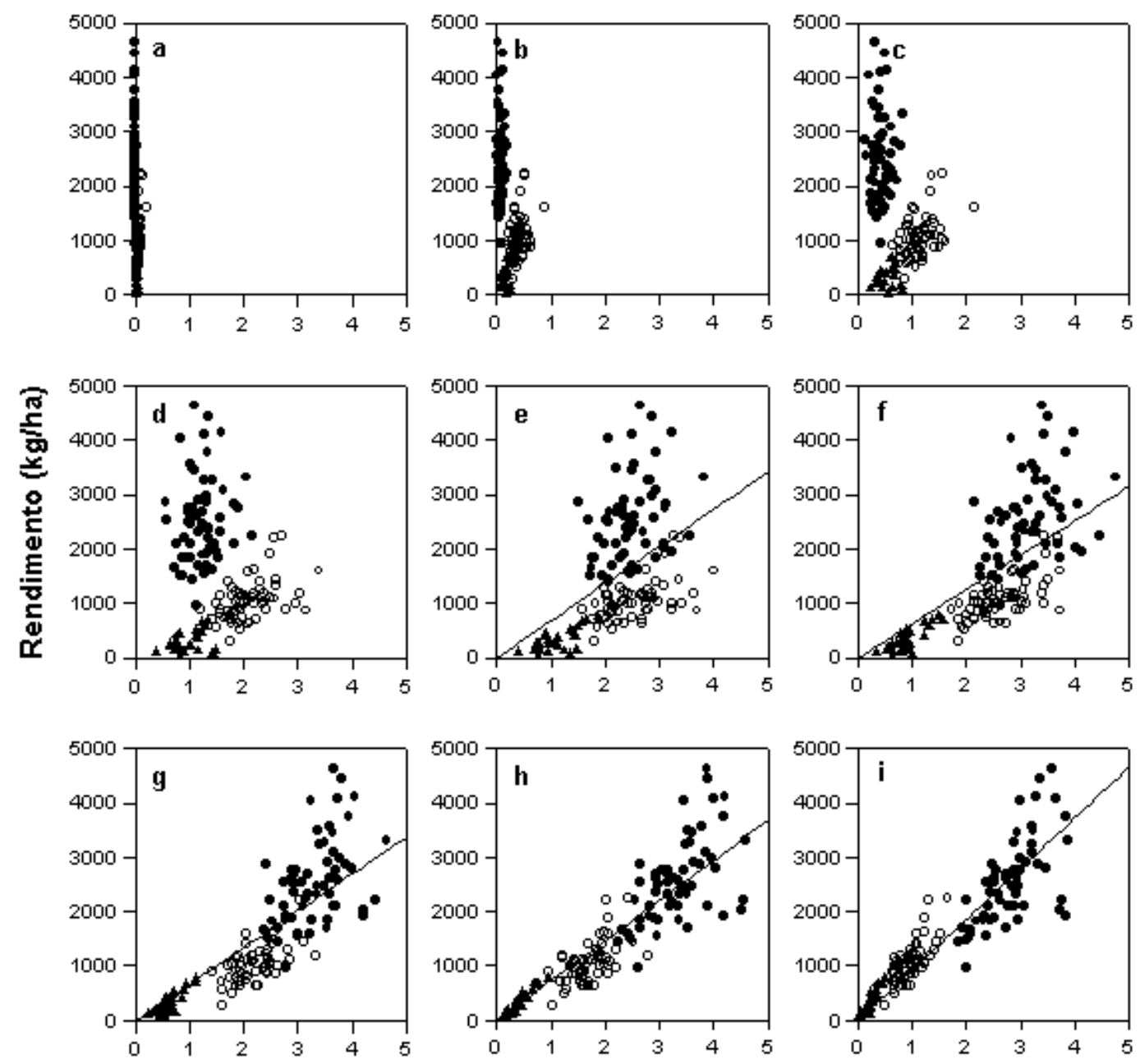

HLAI

Apêndice 24 - HLAI nas diferentes fases de desenvolvimento (V4 - a, V10 - b, V18 - c, R1 - d, R2 - e, R3 - f, R5.5 - g, R6 - h, R7 - i) versus rendimento (kg/ha), para mancha de Alternaria em girassol, semeado em quatro épocas (outubro - círculo cheio, novembro - círculo vazio, dezembro - triângulo cheio), na safra 1998/1999. Linhas representam ajuste do modelo linear com interseção forçada a zero. 

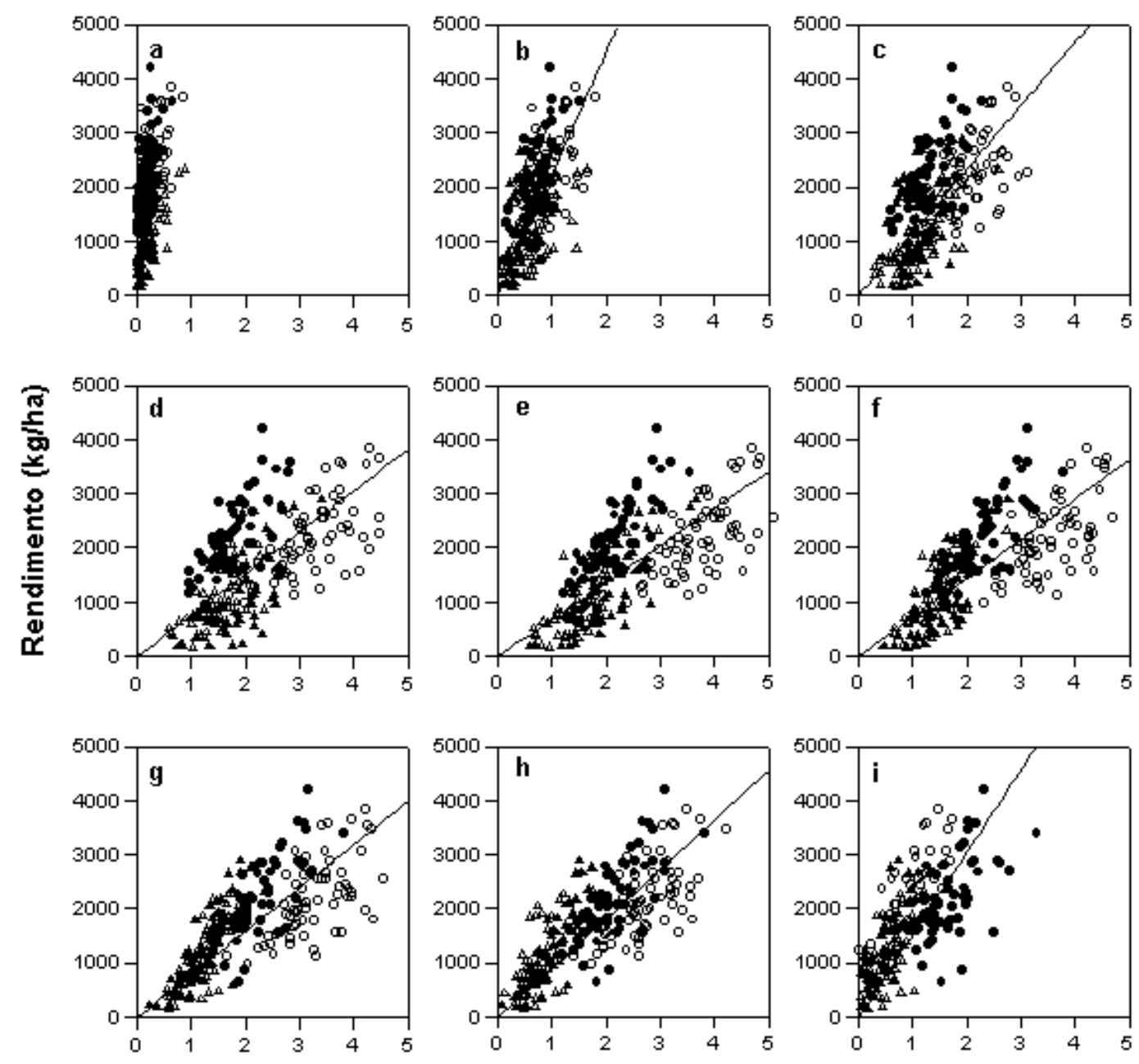

HLAI

Apêndice 25 - HLAI nas diferentes fases de desenvolvimento (V10 - a, V16 - b, R2 - c, R3 - d, R4 - e, R5.9 - f, R6 - g, R7 - h, R8 - i) versus rendimento (kg/ha), para mancha de Alternaria em girassol, semeado em quatro épocas (outubro - círculo cheio, novembro - círculo vazio, dezembro - triângulo cheio, janeiro - triângulo vazio), na safra 1999/2000. Linhas representam ajuste do modelo linear com interseção forçada a zero. 

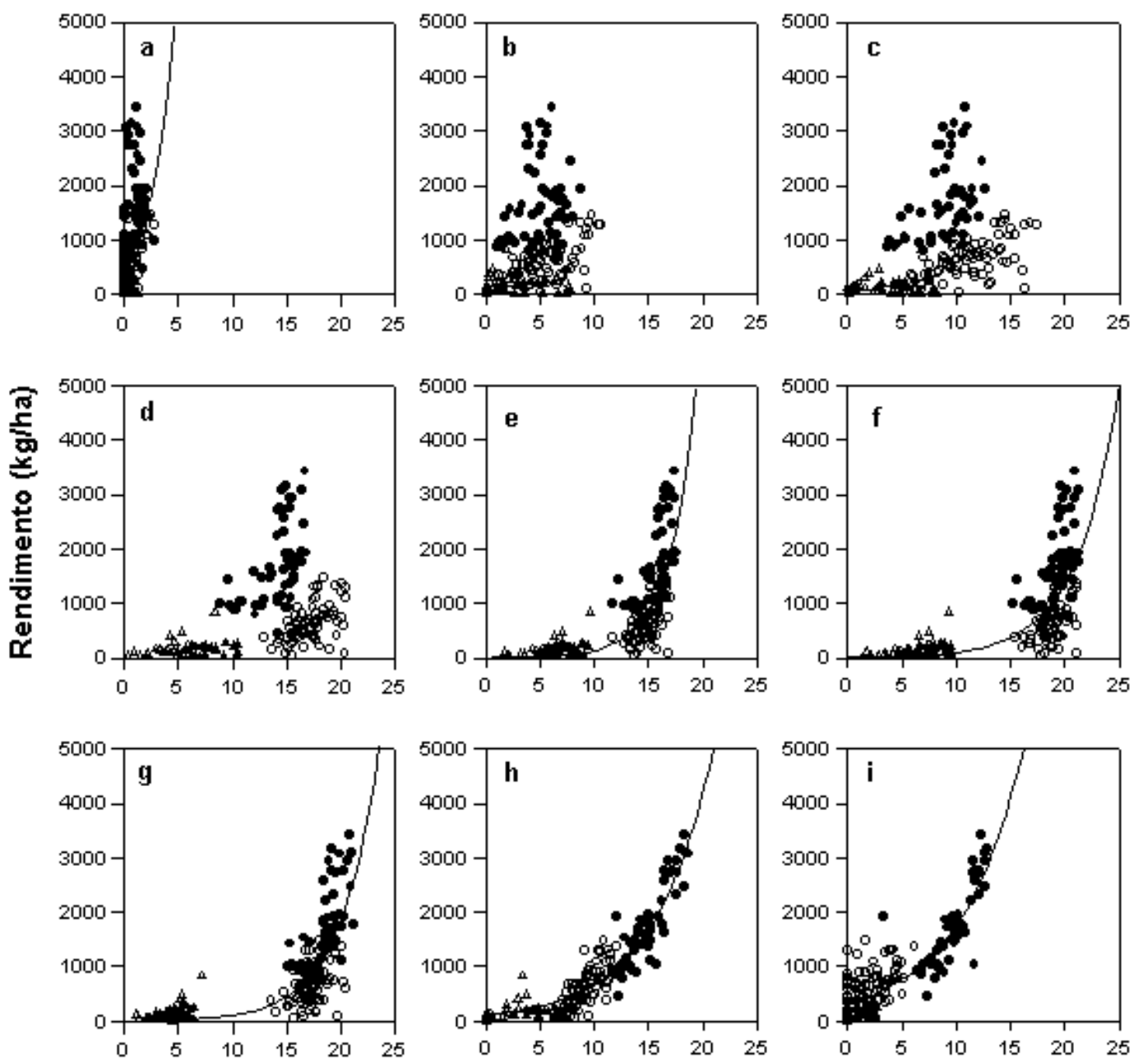

HRI

Apêndice 26 - HRI $\left(\mathrm{MJ} \mathrm{m}^{-2}\right)$ nas diferentes fases de desenvolvimento (V10 - a, V15 - b, V21 - c, R1 - d, R3 - e, R5.5 - f, R6 - g, R7 - h, R8 - i) versus rendimento (kg/ha), para mancha de Alternaria em girassol, semeado em quatro épocas (outubro - círculo cheio, novembro - círculo vazio, dezembro triângulo cheio, janeiro - triângulo vazio), na safra 1997/1998. Linhas representam ajuste do modelo exponencial. 

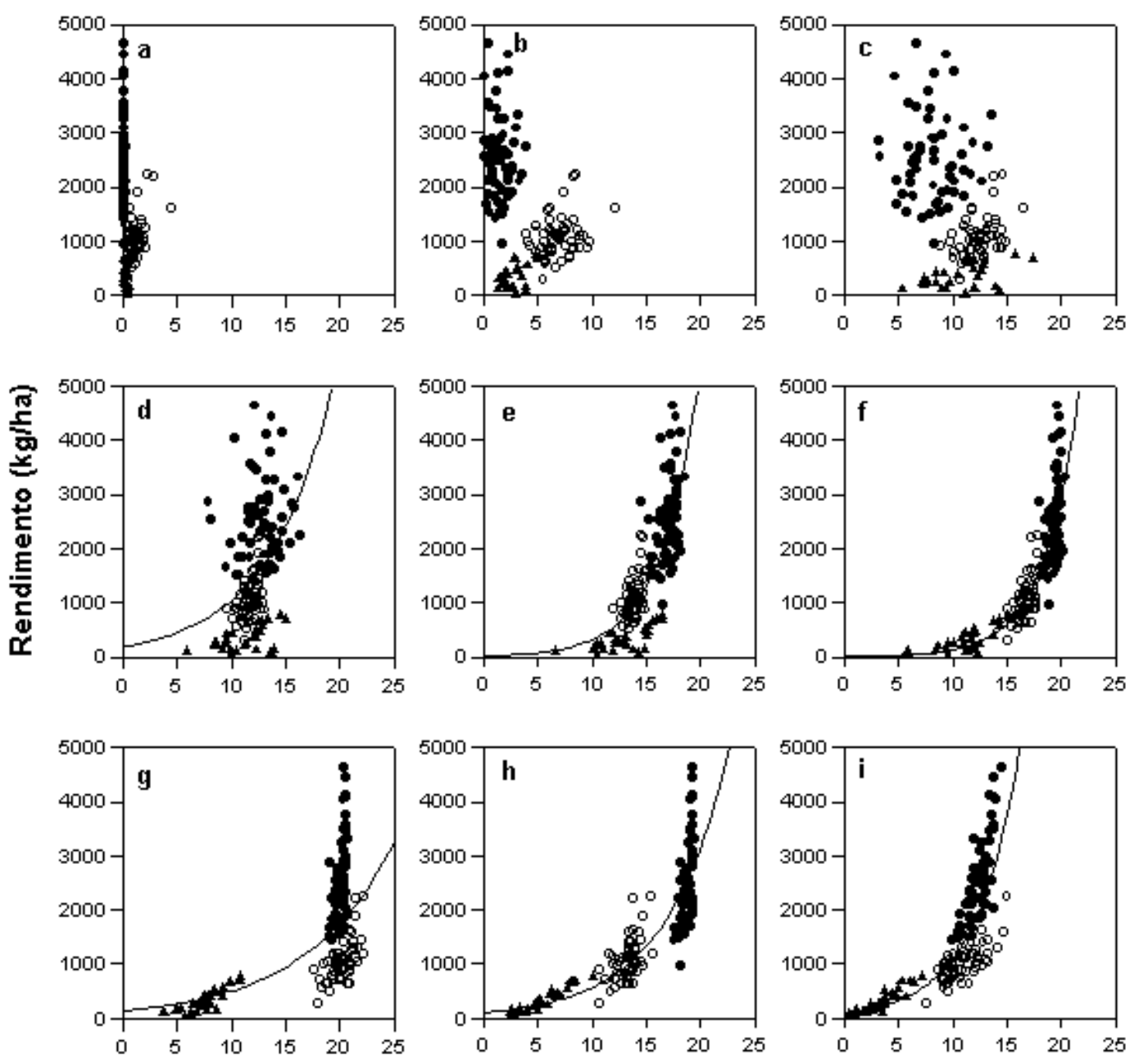

HRI

Apêndice 27 - HRI $\left(\mathrm{MJ} \mathrm{m}^{-2}\right)$ nas diferentes fases de desenvolvimento (V4 - a, V10 - b, V18 - c, R1 - d, R2 - e, R3 - f, R5.5 - g, R6 - h, R7 - i) versus rendimento $(\mathrm{kg} / \mathrm{ha})$, para mancha de Alternaria em girassol, semeado em quatro épocas (outubro - círculo cheio, novembro - círculo vazio, dezembro triângulo cheio), na safra 1998/1999. Linhas representam ajuste do modelo exponencial. 

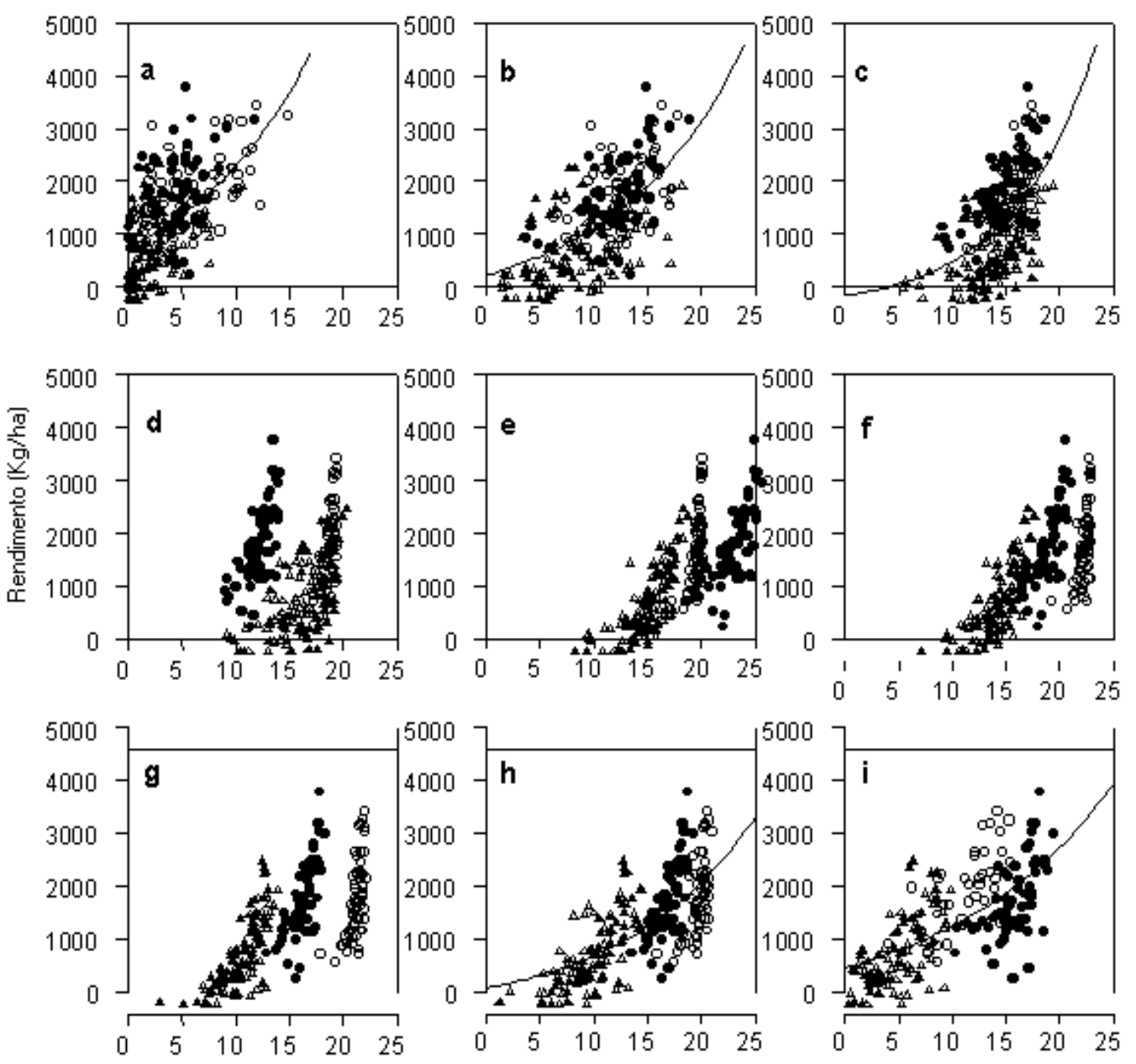

HR

Apêndice 28 - HRI $\left(\mathrm{MJ} \mathrm{m}^{-2}\right)$ nas diferentes fases de desenvolvimento (V10 - a, V16 - b, R2 - c, R3 - d, R4 - e, R5.9 - f, R6 - g, R7 - h, R8 - i) versus rendimento (kg/ha), para mancha de Alternaria em girassol, semeado em quatro épocas (outubro - círculo cheio, novembro - círculo vazio, dezembro triângulo cheio, janeiro - triângulo vazio), na safra 1999/2000. Linhas representam ajuste do modelo exponencial. 